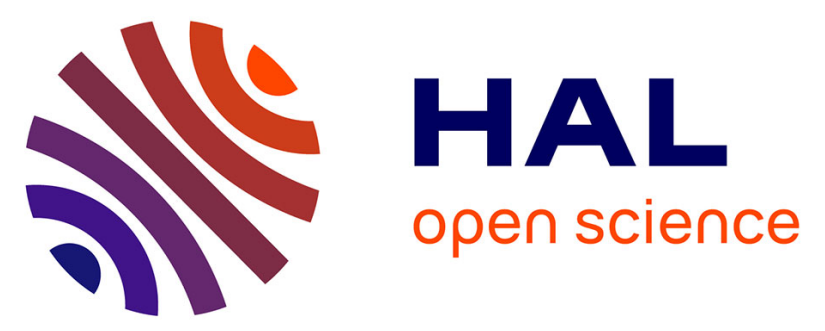

\title{
Ten years of global burned area products from spaceborne remote sensing-A review: Analysis of user needs and recommendations for future developments
}

Florent Mouillot, Martin Schultz, Chao Yue, Patricia Cadule, Kevin Tansey, Philippe Ciais, Emilio Chuvieco

\section{To cite this version:}

Florent Mouillot, Martin Schultz, Chao Yue, Patricia Cadule, Kevin Tansey, et al.. Ten years of global burned area products from spaceborne remote sensing-A review: Analysis of user needs and recommendations for future developments. International Journal of Applied Earth Observation and Geoinformation, 2014, 26, pp.64-79. 10.1016/j.jag.2013.05.014 . hal-02927934

\section{HAL Id: hal-02927934 \\ https://hal.science/hal-02927934}

Submitted on 28 Jun 2021

HAL is a multi-disciplinary open access archive for the deposit and dissemination of scientific research documents, whether they are published or not. The documents may come from teaching and research institutions in France or abroad, or from public or private research centers.
L'archive ouverte pluridisciplinaire HAL, est destinée au dépôt et à la diffusion de documents scientifiques de niveau recherche, publiés ou non, émanant des établissements d'enseignement et de recherche français ou étrangers, des laboratoires publics ou privés. 
Ten years of global burned area products from spaceborne remote sensing - A review:

Analysis of user needs and recommendations for future developments

Florent MOUILLOT ${ }^{(1)}$, Martin G. Schultz ${ }^{(2)}$, Chao YUE $^{(3)}$, Patricia CADULE ${ }^{(3)}$, Kevin TANSEY $^{(4)}$, Philippe CIAIS $^{(3)}$, Emilio CHUVIECO ${ }^{(5)}$

1: IRD, UMR CEFE, 1919 route de mende, 34203 Montpellier Cedex 5, France

2 : Forschungszentrum Jülich GmbH, 52428 Jülich , Germany

3 : LSCE, CEA, 91191 Gif s/Yvette Cedex, France

4: University of Leicester, Department of Geography, Leicester, LE1 7RH, United Kingdom

5: Univ. de Alcala, facultad de Filosofia y lettras, Calle Colegios 2, 28801 Alcala de Henares, Spain 


\section{Abstract}

Early global estimates of carbon emissions from biomass burning were based on empirical assumptions of fire return interval in different biomes in the 1980's. Since then, significant improvements of spaceborne remote sensing sensors have resulted in an increasing number of derived products characterising the detection of active fire or the subsequent burned area. When coupled with global land cover and vegetation models allowing for spatially explicit fuel biomass estimates, the use of these products help to yield important information about the spatial and the temporal variability of emission estimates. The availability of multi-year products ( $>10$ years) leads to a better understanding of uncertainties in addition to increasing accuracy. We surveyed a wide range of users of global fire data products whilst also undertaking a review of the latest scientific literature. Two user groups were identified, the first being global climate and vegetation modellers and the second being regional land managers.. Based on this review, we present here the current needs covering the range of end-users. We identified the increasing use of BA products since the year 2000 with an increasing use of MODIS as a reference dataset. Scientific topics using these BA products have increased in diversity and area of application, from global fire emissions (for which BA products were initially developed) to regional studies with increasing use for ecosystem management planning. There is a significant need from the atmospheric science community for low spatial resolution (gridded, $1 / 2$ degree cell) and long time series data characterised with supplementary information concerning the accuracy in timing of the fire and reductions of omission/commission errors. There is also a strong need for precisely characterising the perimeter and contour of the fire scar for better assimilation with land cover maps and fire intensity. Computer and earth observation facilities remain a significant gap between ideal accuracies and the realistic ones, which must be fully quantified and comprehensive for an actual use in global fire emissions or regional land management studies. 


\section{Introduction}

As early as the 1980's, fire disturbance has been considered as an essential climate variable (ECV) (Crutzen et al. 1979, Crutzen and Andreae 1990, Hao and Liu 1994), and later by the Global Climate Observing System (GCOS 2010) program as well as by several other internationally coordinated science plans and research programmes. The main goal of current research is to move towards a better understanding of the earth system for more accurate predictions of various feedbacks in the future scenarios of climate change. It is now recognised that fire is one of the most important disturbances for terrestrial ecosystems causing considerable uncertainties in carbon balance, and in the atmospheric composition of reactive gases and aerosols (GCOS, 2011). In many regions of the world, the variability of the terrestrial carbon balance is driven by fire disturbance, including emissions during the burning itself, but also subsequent ecosystem recovery and regrowth, which may take place over long time scales (Mouillot and Field 2005, Field et al. 1999, Chen et al. 2000). Associated carbon fluxes, particles or aerosol emissions in the atmosphere then play a significant role on the global energy balance and subsequent climate trends. Therefore better fire observations and improved estimates of fire impacts will reduce uncertainty and improve prediction for future ecosystem feedbacks on biosphere/atmosphere interactions.

The research on global Burned Area (BA) remote sensing products started in the late 1980 's with the technical work to deliver the global representation of fire number and burned area. Regional analysis of burned areas showed the potentials of middle resolution sensors to discriminate fire-affected areas (Chuvieco and Congalton 1988, Furyaev 1985, Milne 1986, Smith and Woodgate 1985). Later on, the first studies oriented towards continental burned area assessment were based on NOAA-AVHRR images, both at continental (Barbosa et al. 1999) and global scales in 2000 (Dwyer et al. 2000). Since the year 2000, several products have been delivered using different algorithms and sensors that we will describe in this paper. An unexpected side effects of these BA development has been the increasing use of these global data for regional fire regime analysis where fire statistics are lacking, and representing nowadays a significant community of users. In this context the European Space Agency's Climate Change Program aims to develop a set of ECV from satellite observations. Within this program the fire_cci project is developing methods to generate long-term and global series of BA products adapted to the needs of climate modellers for which global datasets started to be developed, but also land managers or local users when local fire 
statistics are lacking. To make the final products more useful, the fire_cci project started from conducting a user requirement analysis, which was aimed to define the scientific profile of current end-users and their specific needs, covering all source of application, including climate modellers, earth scientists, ecologists and fire managers. The needs of BA information for each user group were defined in terms of coverage, accuracy, resolution, time delivery. This survey was complemented by a literature review, which analyzed the previous uses of BA datasets in the widest range of topics, but including the most representative of climate, carbon and atmospheric models. This paper provides a summary of current global BA data products and their uncertainties, limitations and applications, then presents the summary of the user-needs analysis, based on a survey of more than 47 questionnaires and finally includes a gap analysis for deriving a set of future needs and requirements that will be used to guide the production of global BA products in the next decades.

\section{Overview of global burnt area data products}

\section{TABLE 1 HERE}

Table 1 provides an overview of the global burned area products described in the literature from 1995 to 2010 . The following sections will discuss the quality and accuracy of current global multi-annual data sets. For details on regionally or temporally restricted products the reader is referred to the literature cited in table 2. Even though the products described were developed with different sensors and algorithms, average yearly estimations of global burned area are fairly similar, in the range of 3.50 to $4.50 \mathrm{Mkm} 2$, with yearly variations depending on weather conditions.

\section{TABLE 2 HERE}

\subsection{GFED (Global Fire Emissions Database)}

The Global Fire Emissions Database Version 3 (GFED3) includes estimations of atmospheric emissions derived from a multi-sensor global burned area data set derived by Giglio et al. (2010). These data are provided as gridded product at $0.5^{\circ}$ resolution and cover the period from 1997 to present and thereby being the longest global burned area record currently available (Giglio et al. 2010). The multi sensor and bias-corrected burned area product has been improved compared with its predecessor GFED2 (Giglio et al. 2006), by using 18 times the quantity of training data for the algorithm implementation. Most input data for the GFED3 was obtained from BA maps generated 
from the $500 \mathrm{~m}$ reflectance channels of MODIS using the direct broadcast (DB) algorithm described by Giglio et al. (2009). This algorithm uses both multitemporal reflectance changes and hotspots derived from the thermal channels. For periods when MODIS BA information was not available, the BA was estimated from a combination of local regression and regional regression trees from active fire data. For the Pre-MODIS era, active fire observations from the TRMM VIRS and ERS ATSR sensors were used, followed by a further correction to ensure consistency with MODIS data. Estimations of yearly global BA from this product range from 330 and 431 Mha with great inter-annual variability.

\subsection{MCD45A1}

The MCD45A1 data is currently the standard MODIS BA product for Collection 5 Level 3. It uses daily data from both Terra and Aqua MODIS at $500 \mathrm{~m}$ spatial resolution. The data set is provided as monthly layers (with the date of BA detection) covering the full period of MODIS operations (2000-present). The MCD45A1 product was generated using an algorithm based on a bi-directional reflectance change detection approach (Roy et al. 2008).

\subsection{L3JRC}

L3JRC global burned area data (Tansey et al. 2008) has been generated for seven years (April 2000 to March 2007) at $1 \mathrm{~km}$ from SPOT VEGETATION data. The product was based on a cooperative project coordinated by the JRC (Joint Research Center, Italy), along with other European centres (University of Leicester, the Université Catholique de Louvain and the Instituto de Investigação Cientifica Tropical, Portugal). The product was generated by using a set of regional algorithms based on the previous experience of the GBA2000 product (Tansey et al., 2004).

\subsection{GLOBCARBON}

The Globcarbon BA product was developed as one of the four land products of the ESA Globcarbon initiative to provide targeted, long-term, suited land products that can be readily merged into earth system models (Plummer et al. 2006, Plummer et al. 2007). Global burned area data were generated at spatial resolution of $1 \mathrm{~km}, 10 \mathrm{~km}$, $0.25^{\circ}$ and $0.5^{\circ}$ with monthly temporal resolution, covering the $1998-2007$ period. The data were produced by applying two regional GBA2000 algorithms on the 1-km SPOT VEGETATION data, and the GLOBSCAR algorithms on ERS2-ATSR2 and ENVISAT 
AATSR data. The product includes the estimation of different sensors-algorithms, as well as a combination of some of them by union and intersection.

\subsection{GBS}

The Global Burned Surfaces was generated by the European Commission - JRC Institute for Environment and Sustainability - Global Vegetation Monitoring Unit. It was derived from daily NOAA-AVHRR images using the reduced resolution (8 km) data set. The series includes the period from 1982 to 1999 , based on a multitemporal change detection algorithm, as described by Carmona-Moreno et al. (2005). The authors note that their product is likely to miss a large fraction of fire activity due to the coarse resolution of the imagery used. The value of this product lies therefore mainly in the analysis of seasonal trends.

\subsection{GLOBSCAR and GBA2000}

These two projects served as a benchmark to develop global BA algorithms. GLOBSCAR was developed by the European Space Agency (ESA) and uses daytime data from ATSR-2 instrument onboard the ERS-2 satellite, while GBA2000 is an initiative of the JRC and it was based on SPOT-VEGETATION data. Experiences from these two projects were later used for the Globcarbon and L3JRC projects.

\section{General overview on the increasing use of BA products reported in the literature since 2000.}

We investigated the use of global BA products based on a database search of peerreviewed papers referenced in Web of Science, and filtered according to keywords concerning the names of at least one of the global fire products previously reviewed or their input sensors for local, regional or global applications, in whatever field of research. Our request identified 231 references for the 2000-2011 period, dealing with the developing, validation or use of global BA products used for global or regional studies (synthesis table and references in Annexe 2) and active fire counts. Figure 1 illustrates the yearly number of references over the decade 2000 - 2011 using BA products information or related products called "active fire counts" from MODIS or ATSR. Papers dealing with global BA products started in 2000, and their number grew up with 5 to 10 publications per year evenly distributed between products generated from MODIS, TRMM, ATSR before 2008. Since 2008, the number of publications per year using satellite BA products increased to more than 15 and the majority of 
publications $(65 \%)$ relied on data from the MODIS instruments. At the same time, 25 scientific publications use active fire counts, mostly derived from MODIS sensor since 2008, while ATSR was mostly used before that year. It can be concluded that the quality of the MODIS products and their easy acquisition stimulated research related to the fire topic.

\section{FIGURE 1 HERE}

We classified the scientific publications using BA products into the following main topics covering different research fields: technical delivery of BA products with their updates (called Earth Observation EO), fire hazard early alarm and survey/penalize systems, BA accuracy analysis or improvement, ecosystems and land management, vegetation models using fire global fire risk assessment modules or fire spread the regional level, and atmospheric sciences (carbon emissions and aerosols or particles during fire events). The contribution of each of these topics in the literature survey is presented in figure 2. Atmospheric chemistry applications remain the dominant application of BA products with $20 \%$ to $50 \%$ of the published studies in our sample. Research applications for fire hazard analysis and forest/ecosystem management actually started later in 2006 and cover now a significant end-user group, implying a wider range of requests than global studies alone.

\section{FIGURE 2 HERE}

The regional distribution of the published papers shows a significant share of global studies (figure 3). Tropical regions follow in importance, particularly in central Africa, the Amazon Basin and SE Asia. This inter-tropical region actually represents more than $60 \%$ of the burned area globally (Mouillot et al. 2005), but most countries in this region do not have operational fire observation systems, and therefore official fire statistics are not very reliable. Additionally, there is a double interest in air chemistry due to the large amount of carbon and aerosols released from these biomes, and a significant demand for forest management and protection from deforestation.

\section{FIGURE 3 HERE}

Since 2006, we can observe an increase in the number of research publications dealing with agricultural fires. These low energy fires were not detected in earlier versions of fire products and could not be considered. As of yet, no conclusive analysis has been performed to quantify the contribution of agricultural fires to, for example, the MODIS burned area products. For the purpose of estimating trace gas and aerosol 
emissions from fires it can be assumed that some overlap exists with bottom-up inventories of agricultural burning that are based on economic statistics.

As a brief summary, the analysis of peer-reviewed research publications highlights the increasing use of MODIS-derived products compared to any other products and the importance of these datasets for the tropics where ground data are lacking. The origin of end-users reflects the increasing accessibility of the dataset to the global community and the increasing independence of these end users in downloading and using these data for local use. We also noticed the significant use of active fire counts rather than BA data, highlighting the interest in high resolution datasets and fire contours. From this analysis, we can expect different user requirements according to the field of application, the extent of the region to be explored, and the country of origin with different expectations and access to the datasets. This analysis also points out that any set of future requirements will be driven by the atmospheric community but will also become closer to the increasing demand for fire hazard and forest managers.

\section{A literature review on BA product applications}

The following section describes the main uses of BA products and tries to summarize their requirements in terms of temporal, spatial and thematic characteristics based on identified gaps and failures.

\subsection{Fire hazard assessment for ecosystem management}

Fire has both positive and negative effects on the ecosystems and society, but most commonly it is considered as a natural hazard, as it affects people's lives and properties and ecosystem services. For this reason, fires tend to be avoided and when countries have an active fire suppression policy, fire risk assessment systems are in operation. Accordingly, the identification of the main factors explaining fire ignition and propagation becomes a very relevant research topic. The validation of those fire risk systems requires having accurate fire statistics available. Both fire ignition points and burned areas are required (Ardakani et al. 2001, Chuvieco et al., 2010, Robbins et al. 2008). In savannah-type ecosystems for example, identifying climatic or human drivers as well as frequently burned areas requires a fairly good representation of fire contours (Devineau et al. 2010, Archibald 2009), to promote fire-free areas where fire sensitive species could be conserved. Accurate fire detection with low spatial shifts is then standard requested information for vulnerable areas (Wright et al. 2007, Ressel et al. 2009). Among these vulnerable areas, we could identify a special focus of interest for 
deforested regions where fire is a major tool for forest clearing. In these regions, however, several authors could deplore some caveats in differentiating fires and other disturbances where reburning and understory fires occur (Van der Werf et al. 2009, LePage et al. 2008, Pereira 2003, Morton et al. 2011).

These results are of interest to fire risk modellers at larger scale who need a conceptual knowledge of processes to be implemented in global fire modules or fire spread/initiation models at global (Thonicke et al. 2010) or regional scale (Anderson et al. 2009). Mapping large fire events in continuous forested ecosystems could contribute to a better understanding of their propagation. Requirements here are an accurate timing of fire occurrence on a daily basis and a finer spatial resolution for more precise fire contours. On the other hand, long time series of fire affected areas are necessary for getting a clear picture of a fire regime with time return intervals much larger than the 10 years available until now, so that most studies, until now had to use a combination of products to get the more accurate and longest time series available (Lepage et al. 2008, Bartalev et al. 2007, Bartsch et al. 2009). Providing a single product covering the longest period available would be a major step forward for fire risk assessment users.

\subsection{Early warning fire alert systems and survey}

The growing impact of catastrophic fire seasons have brought the public interest of establishing near real time fire alert systems. Early warning and fast extinction of fires are the only chance to avoid major negative impacts of fires on society and ecosystems. These requirements have already been listed by Davies et al. (2009) for MODIS products, or have been pointed out in scientific papers (Schroeder et al. 2008). Some efforts have already started to provide this information through active fire detection rather than burnt area (Biswajeet and Hamid 2010, Zhang et al. 2008). Nevertheless, a major requirement on the improvement of BA product when considering lower spatial resolution getting closer to active counts, would be the timing of the fire signal delivery with low omission errors that could lead to missed alerts with significant consequences. Commission errors would lead to false alerts that are less damageable if they remain in a reasonable proportion.

The political use of fire detection for survey and penalisation for illegal fires recently emerged in Bolivia (Redo et al. 2011) or Indonesia (Harwell 2000). We could also identify the use of fire detection as a proxy for societal conflict in some regions and its application for early warning and rapid response efforts of interest to human rights, humanitarian and security communities, as already assessed for Darfur (Bromley 
2010). This political use of fire information then brings an additional constraint on fire detection accuracy or at least a clear explanation of uncertainties to prevent any responsibilities in false alarms or inaccurate locations that could penalise local inhabitants.

\subsection{Atmospheric chemistry}

Since the early work by Radke et al. (1978), Crutzen et al. (1979) and Seiler and Crutzen (1980) the interest in biomass burning as major emission source for trace gases and aerosols has gradually increased to become an important focus point nowadays. The underlying data were traditionally derived from national forest fire assessments (FAO 2001). During the 1990's, continental scale or regional scale studies started to provide remotely sensed spatially explicit fire datasets (Barbosa et al. 1999, Eva and Lambin 1998a,b). At the end of the 1990's and the early 2000's, the first global fire products became available from global remote sensing, providing a spatially and seasonally explicit distribution of fires and the first studies with fire emissions in atmospheric chemistry models derived from remote sensing data appeared. The aim was to provide an accurate estimate of the interannual variability of combusted biomass and biomass burning emissions (Schultz 2002) and its seasonal variability (Generoso et al. 2003) in a spatially explicit manner at the global scale. Since then, it has become a de-facto standard in atmospheric chemistry models to prescribe trace gas emissions from large-scale vegetation burns. These are based on remote sensing data and an empirical conversion of area burned and average biomass amount per grid cell into carbon and other compounds released into the atmosphere.

Field experiments and laboratory burns of litter material from various ecosystems provided insight into the emission factors for many gases and aerosols (Andreae and Merlet 2001, Akagi et al. 2011). Due to uncertainties in the burned area provided, maximum and minimum values were delivered. The time period covered was not exceeding 10 years, and they were mainly used in areas where no fire statistics existed, as in the tropics. For regions where fire statistics are available, it has been possible to construct longer time series of fire emissions (Chen et al. 2000, Mouillot et al. 2006, Schultz et al. 2008, Mieville et al. 2010).

Fire emissions can be estimated from two approaches: bottom-up and top-down. The former tries to estimate the main factors contributing to emissions from biomass burning, while the latter tries to estimate the actual amount of gas released from the observation of a fire itself or from atmospheric concentrations of that gas. The bottom- 
up approach has been the most extended, based on the Seiler and Crutzen (1980)'s model:

$$
M_{i}=A \cdot A F L \cdot \beta \cdot E_{i}
$$

Where $\mathbf{M i}$ is the emission of compound $\mathbf{i}\left(\mathrm{g} \mathrm{m}^{-2}\right), \mathbf{A}$ is the area burned $\left(\mathrm{m}^{2}\right), A F L$ is the available fuel load $\left(\mathrm{g} \mathrm{m}^{-2}\right), \beta$ is the burning efficiency (i.e. fraction of AFL that is consumed in the fire and released into the atmosphere), and $\mathbf{E F}_{\mathbf{i}}$ is the emission factor of compound $\mathbf{i}\left(\mathrm{g}_{\mathrm{i}} \cdot \mathrm{g}_{\mathrm{DM}}{ }^{-1}\right.$, where DM means dry matter).

Global BA products provide $A$ in the above equation, which can be coupled with spatially explicit estimates of AFL and EF based on vegetation modelling for biomass, litter and its water status. This approach is the basis for the Global Fire Emissions Database (GFED) (Van der Werf et al., 2010).

The alternative estimates of gas emissions are based on a combination of active fire counts and TOMS aerosol optical depth retrievals (Duncan et al., 2003), daily active fires from geostationary satellites (Reid et al., 2009) or - more recently - emissions estimates based on a multi-sensor fire radiative power retrieval (Kaiser et al., 2009).

\subsection{Biogeochemical models}

The estimation of biomass from before the fire has been sometimes approached from spatially explicit vegetation models that simulate carbon assimilation and respiration, estimating fuel biomass and soil litter loads, their water status and the subsequent dynamic and post-disturbance effects. Until the end of the 1990's, major efforts were focused on conceptualising models able to simulate the seasonal and inter-annual variations of these fluxes at the global level based on soil and plant functional parameters, and climate (precipitation, solar radiation and temperature). These models can be divided into dynamic vegetation models that simulate intrinsically species composition and the seasonal variation in the canopy layer where NPP occurs, and biogeochemical models that are forced by fixed land cover, fire and soils maps and by the fraction of photosynthetically active radiation (FAPAR) intercepted by leaves, globally estimated by remote sensing and reviewed in Palacios-Orueta et al. (2005). Biogeochemical models are then used for historical short term (over a decade) studies where changes in land cover are assumed to be not significant at a global scale. The CASA model was initially developed for estimating seasonal and inter-annual variability in biosphere/atmosphere exchanges (Potter et al. 1993, Field et al. 1995). The combustion module developed in CASA by Van der Werf et al. (2006) for GFED, and 
Mouillot et al. (2006) for historical long term fire emissions, accounts for fire effects on changes in carbon stocks, direct emissions from combustion and subsequent indirect effects on the decomposition of woody debris resulting from incomplete combustion (Potter et al. 1998). Emissions ( $\mathbf{M}_{\mathrm{BB}}$ ) are calculated for the burning of leaves, wood, and litter carbon pools with specific combustion completeness parameters specific to these pools and to the biomes. Combustion completeness is then modified according to soil water content, the driest conditions being the more complete. Biome-BGC (Running et al., 1993) is also a widely used model for forest ecosystems, and has a range of global and regional application but has rarely been used in global fire studies (Wang et al., 2011). Fire-BGC (Keane et al., 1989), the stand level forest model designed for fire application is the mostly used BGC derived model implying fires but mostly at the landscape scale.

When applied at global scales, vegetation models require a spatially explicit representation of burned areas as a forced input for calculating combustion. Biogeochemical models require the accurate location and timing of fires for a better simulation of fire emission and combustion efficiency and further use in atmospheric models. We'll note here also the importance of multi-year datasets, as a single year for BA product is not relevant due to the high interannual variability and indirect effects of previously burnt areas on present fuel biomass. However model requirements in terms of BA specificity are still low compared to the current resolution of spaceborne sensors with global coverage, as simulations are performed at $0.5^{\circ}$ or $1^{\circ}$ resolution and on monthly basis.

\subsection{Dynamic Global Vegetation Models (DGVMs)}

DGVMs simulate water, energy and carbon exchanges between the terrestrial biosphere and the atmosphere, but instead of using a fixed land cover derived from global remote sensing, they can simulate the global distribution of vegetation dynamically so that land cover (species composition and biomass) is calculated from climate and soil types that allow the germination, growth and survival of species (Sitch et al., 2003). Indeed they can be used under historical and future climate change scenarios. In these models, the fire module calculates direct and indirect carbon emissions from combustion as in the biogeochemical models, but also the potential changes in species composition according to the functional traits associated to resistance to fire and post fire regeneration (Pausas et al. 2004). In these models, fire information can be either inserted from global remote sensing datasets as in the biogeochemical models for historical fire emission assessments, but they have also 
been associated with the development of fire risk modules based on more or less complex processes able to reproduce fire hazard based on climatic and anthropogenic ignition and fire spread. A review of existing DGVMs and their related fire modules are presented in table 3 . Identifying processes and validating the simulated fire hazards both use global BA product. Landscape fire succession models (LFSM, see Keane et al. (2004) for a review) simulate fire spread at finer scale for local applications but cannot be used yet for global studies due to computer resources and the lack of data for wind downscaling in time and space that drive fire spread (Arca et al., 2007, Duguy et al. 2007). Only few studies yet applied global fire products for coarse resolution fire spread assessment (Anderson et al. 2009, Loboda and Csiszar 2007).

\section{TABLE 3 HERE}

For the fire modules embedded in DGVMs, requirements from fire information are fairly coarse, as these models are not able to simulate the exact timing of fires due the high contingency of fires events, but can simulate an average fire regime that has to be compared with actual data. Seasonality, fire number and fire size are the only information requested by this community but validations are usually performed at the biome level or "ecoregion" rather than pixel to pixel so the accuracy in the fire location and date of the burning is low. BA products are used as calibration dataset for fire hazard modules, or as a validation dataset to estimate the validity of these fire modules globally.

Getting a better accuracy on burned areas, exact location and timing is of course a challenge that suits all the vegetation modellers requests as model resolution will increase. However this performance in accuracy has to be closely linked with better performance in land cover mapping as emissions are a function of the burned area, but also by the biomass available for burning. Usually a single land cover map is used e.g. Global Land cover GLC2000 (Bartholomé and Belward 2005), but recent studies pointed out the discrepancy between these products particularly for low density tree cover (Herold et al., 2008, Mc Callum et al., 2006), and efforts are still ongoing for increasing accuracy for land cover maps in vegetation models (Lawrence et al., 2007). 


\section{Temporal and spatial accuracy of current BA products}

\subsection{Current weaknesses and failures: a review of evaluation and inter- comparison of BA products}

Most peer-reviewed papers reviewed in our analysis identify the benefits of BA products where local ground based statistics are lacking. However, comparisons with high resolution datasets highlight their limitations to characterize small fires (Sa et al., 2007), with a threshold of 105 ha for Hawbaker et al. (2008) or 120 ha for Giglio et al. (2009), or low intensity fires, which are frequent in shifting cultivation (Miettinen et al., 2007) or shrubland fires (De Klerk 2008). Omission and commission errors have been requested early in the BA product development process (Korontzi et al., 2004) and remain a key variable to account for. For example, accuracy of existing BA products range between $70 \%$ and $80 \%$ (Kushida et al., 2010, Diagne et al., 2010, Loboda et al., 2007, Schroeder et al., 2008) but can fall down to $40 \%$ in some biomes (Giglio et al., 2009) or when using coarser resolution sensors (such as NOAA-AVHRR). Since AVHRR is the only sensor available from 1982 to 1997, finding a balance between length of the time series and accuracy defines the framework for new forthcoming BA products.

As soon as the first BA products have been built and delivered independently, intercomparison exercises could point out the general agreement for the global fire distribution across biomes but with major discrepancies when comparing databases pixel to pixel (Boschetti et al., 2004, Simon et al., 2004, Tansey et al., 2004). Identifying discrepancies between products could point out biomes with more significant weaknesses to account for in modelling error assessments and summarized in table 4. Also, specific studies could identify signal disturbances as heavy clouds during the fire season, depending on data processing algorithm (Roy et al., 2005b, Giglio et al., 2009) more or less robust to the presence of clouds.

\section{TABLE 4}

Based on these acknowledged discrepancies between different BA products that are part of the fire detection procedure, Simon et al. (2004) stressed the need for precise user requirement for matching the needs with the technology when necessary. The current BA products limitations reviewed here already bring the technical limitations that have to be overcome before launching finer resolution datasets (De Klerk 2008). 
In addition, to refine the acknowledged caveats of existing BA products, recent technical studies aim at developing and testing new outputs, that reveal requirements expected by end-users as fire energy (Boschetti and Roy 2009, Ellicott et al., 2009), low intensity fire for crop residue burning (Punia et al., 2008), fire temperature and fire size (Eckman et al. 2008), or a better fire detection in the tropics (Peng et al., 2008). These requests should be considered carefully for algorithm development and output delivery for a further extensive use of the BA product.

Finally, the latest technologies for advertising, communicating, accessing data and early warning of product delivery, have to be considered interacting with already existing users, but furthermore for a user community not linked with recent fire research activities, as performed by the MODIS team (Davies et al. 2009, Trigg and Roy 2007).

\subsection{Forthcoming targets for BA products: a review of requirements identified by previous international science programs}

Several international science plans/programs dealing with global fire assessment produced a set of target requirements for fire observation. Here we reviewed the currently undergoing key internationally coordinated science projects/plans that covered the topic of fire. In this section, we extract accuracy targets expressed by the recommendations of the following programmes/reports ${ }^{1}$ : GCOS-138 (GCOS 2010, 2011), GTOS T13 (GTOS 2009), GEO Carbon Strategy (Ciais et al. 2010), IGOS Carbon Theme (Ciais et al. 2004), IGOS Land Theme (Townshend et al. 2008), NASA Fire ESDR Whitepaper et (Justice al., 2011)(http://landportal.gsfc.nasa.gov/Documents/ESDR/Fire Justice whitepaper.pdf).

Existing BA products caveats have been identified and desired requirements for the fire disturbance observation were provided and summarized in table 5. The table includes information from six international programs. The details of target fire observation

\footnotetext{
${ }^{1}$ Information of these international programs can be found in their web sites: http://www.wmo.int/pages/prog/gcos/index.php?name=News; http://www.fao.org/gtos/; http://www.globalcarbonproject.org/misc/JournalSummaryGEO.htm; http://www.eohandbook.com/igosp/Carbon.htm, http://www.eohandbook.com/igosp/Land.htm,
} 
requirements in these programs are quite different, with GCOS-138 covering much more detailed information, while GEO carbon strategy having only a brief statement.

\section{TABLE 5 HERE}

Nevertheless, it should also be confirmed that, a core set of characteristics for global burned area products can be extracted from the proposed requirements by these projects. The global burned area data must be or have:

- Long-term series data for understanding the long-term fire, climate and vegetation interaction. These series can be generated from various sensors but temporal consistence should be assured.

- Temporal stability and consistency, within 5\%

- Temporal resolution, daily data with original spatial resolution of the sensor, weekly, 10-day or monthly basis on global scale

- Spatial resolution, originally $250 \mathrm{~m}$ (or minimum $500 \mathrm{~m}$ ), horizontal resolution $1 \mathrm{~km}$ acceptable, 0.5 degree or higher resolution on global scale

- Accuracy: highest standard 5\% (maximum error of omission and commission), with demonstrated systematic and adequate validation using internationally agreed validation protocol.

- Error tractability and uncertainty characterization, in a manner that can be easily understood and utilized by users in various applications.

- Easy access to data, including auxiliary information and metadata on vegetation cover, burn severity etc

These general recommendationsare not linked to existing capabilities (or those available in the near future from planned satellites). Again in some program reports or documents, it's pointed out proposed requirements can only be met under certain conditions with existing observing system and cannot be met in a systematic way. Therefore the final conclusion would be the design of new burned area data must be centred on these core characteristics or aimed for the highest standard in each characteristic, but with current capabilities, they will not be met systematically.

We found that fire information requirements from global spaceborne observations in international science programs take into account existing capabilities and give some recommendations for improved fire products in the future. But it also should be noted that partly due to the lack of coordination between these programmes (and to their different objectives) their specific requirements vary significantly. In some programmes, 
only brief mention is made of specific requirements of burned area products. Also there is generally a lack of complete and in-detail linkage between the recommended requirements and the existing capabilities, or the capabilities that will be available in the near future from planned satellites. Nevertheless a core set of characteristics for global burned area products can be extracted from the proposed requirements by these projects. Getting a continuous time series of BA beginning in 1982 when the first AVHRR data are available is recognised by most programs as critical to get a better understanding of fire - vegetation interactions. This "requirement" implies a temporal stability and consistency between sensors. Once this main goal is achieved, the second most important "requirement" is the need of daily temporal resolution and $250 \mathrm{~m}$ or better spatial resolution over the globe. This would be the next goal with secondary products aggregated at a weekly or monthly time step and $500 \mathrm{~m}, 1 \mathrm{~km}$ or $0.5^{\circ}$ resolution would be fine for most applications. To decrease misuse of this BA products, bias and random error should be better characterized and documented as well. The design of new burned area data must be centred on these core characteristics and aimed for the highest standard in each characteristic.

\section{Identification of requirements for forthcoming BA products: a questionnaire to end-users}

\subsection{Questionnaire format}

We designed a questionnaire (Annexe 1) aiming at identifying and defining requirements for specific applications of burned area products in order to deliver the product consistent with the users' needs. This questionnaire was sent to targeted endusers from the authors of published papers using BA products, and refines the outcomes of the literature review. End users were classified according to their working country, the field of research they are involved in and their use of BA products within the categories earth observation (EO), modelling (MOD), data assimilation (DA), and other.

In the design of the questionnaire a balance was sought between identifying the "ideal" needs of a user (i.e. irrespective of the technical possibilities that satellite data can principally offer) and the "realistic" needs which take into account the physical limitations of existing sensors. Several questions were directed toward specific product types that can be generated from the remote sensing data. A set of seven pre-defined product types were listed as "plausible products" and users had the opportunity to 
formulate different product characteristics or add requirements to the pre-defined set. Five product types were gridded data sets with different spatial and temporal resolution, the other two were "burned patches" (i.e. a list of individual fire events or fire perimeters) and "burned pixel" (i.e. a list of individual satellite sensor pixels classified as burned) data sets. For each type of proposed product an extensive set of possible quality flags and metadata information was suggested and users were asked to rank them in terms of importance for their work.

The questionnaire assessed various accuracy requirements with respect to the burned area detection and quantification, the geolocation and the timing of fire events and the temporal stability of the product. For each aspect of product accuracy, the users were asked to give their requirements for three categories: "ideal" (wish I had this), "reasonable" (would be good if they can do this) and "minimum" (if it is any worse then it becomes useless). These terms can be interpreted similar to the GCOS terminology of "target", "goal" and "threshold" objectives. User requirements concerning the completeness and robustness of burned area (or fire) detection were queried by asking for acceptable omission and commission errors, respectively. Finally, the users were asked about the file format, metadata conventions and data delivery mechanisms and their preferred way to access the data.

\subsection{End-user description}

A total of 47 end-users answered the questionnaire. The majority of answers were from researchers working in Europe, followed by people working in North America and South America. Two responses each came from Asia and Australia. This geographical distribution mimics the origin of authors found in the literature survey but with a larger representation of European researchers (Fig. 4a). Among these users, 15 belong to the earth observation (EO) community, 17 to the modelling (MOD) community, 4 to the data assimilation (DA) group and 11 to other areas of expertise, in accordance with the field of research distribution in the literature survey (Fig 4b).

\section{FIGURE 4}

The MOD+DA responses exhibit a focus on carbon cycle monitoring and dynamic vegetation modelling, whereas scientists working in the field of atmospheric chemistry tend to belong to the OTHER group. At the interface between the MOD+DA and EO communities are applications related to species migration and the production of landcover maps. BA products are also widely used for fire hazard monitoring and 
assessment of post-fire conditions. Besides the mainstream applications asked for in the questionnaire, burned area products may be used in many fields of research in accordance with the bibliographical review of application. About $50 \%$ of users specified the satellite fire products they have been working with in the past and provided comments on the major advantages and disadvantages of these products. The majority of fire products that are presently in use are derived from MODIS, confirming the results from the bibliographical analysis. In the MOD+DA community, several users employ the GFED products (v2, Van der Werf et al. (2006), and v3, Van der Werf et al. (2010)). In the EO community preference is given to the Giglio et al. (2009, 2010), Dempewolf et al., (2007) or Roy et al., (2008) products. Alternatively, the respondents developed their own retrieval products based on MODIS, SPOT/VEGETATION, NOAA/AVHRR or Landsat data. Only few users employ ESA data and if they do, they generally use fire hot spot products rather than burned area.

Main advantages of the currently available fire products are their free availability and the fact that they can be obtained through fast mechanisms of delivery. However, the majority of current products are reported to fall short of the desired accuracy and spatial or temporal resolution. Furthermore, most existing products provide only information on hot spots and have no information on BA. In the case of GFED products the major advantage pointed out by the users is that it has a long time series. The major disadvantages associated with GFED are the ASCII data format, and the fact that this product is not available in real time. In the case of the Giglio et al. $(2009,2010)$ products, the major advantage and disadvantage is, respectively, the good performance and the lack of global coverage.

\subsection{Product Requirements}

\subsubsection{Type of data products}

Fig. 5 shows the score-ranking of the proposed pre-defined product types. Clearly, the users give preference to data products that allow identification of individual fires or regional-scale applications (i.e. relatively well-resolved gridded products). Researchers with coarser resolution models generally prefer gridded products, while scientists applying models at the regional or landscape scale prefer more detailed burned patch or fire pixel information. While several people responded that they prefer to have the option of downloading a coarser-scale product in order to limit the data volume and processing, most say that they would also accommodate the finer resolution products. 
Requirements on projection and coordinate system used converged toward the lat/lon coordinate system.

\section{FIGURE 5 HERE}

\subsubsection{Accuracy requirements}

The highest quality standard for the BA product appears as key requirement for future BA products (Table 6). While there is considerable spread from more stringent to much more relaxed quality objectives, the general consensus for the accuracy requirement is: ideal $=5 \%$ error, reasonable $=15 \%$ error, minimum $=25 \%$ error. There is no obvious relation of these requirements to the users' model resolution. The dependence of accuracy requirements on scale was mentioned in Roy et al. (2006). Therefore, the questionnaire asked for the required level of accuracy for regional BA and for each single fire. Requirements were tighter for regional BA (10\% error) assessments as the users for single fires admit the difficulties to shape fire, even with low resolution images (20\% error). When classifying errors into omission and commission errors, several users stated that a certain omission and commission error is acceptable as long as they are both similar. However, the majority of users want to see slightly more stringent requirements applied to commission errors (ideal $=3.7 \%$, reasonable $=10.6 \%$, minimum $=17.1 \%$ ) than to omission errors (ideal $=4.4 \%$, reasonable $=13.1 \%$, minimum $=19.1 \%$ ). There is no discernible trend of accuracy requirements with model resolution.

\section{TABLE 6 HERE}

\subsubsection{Geolocation}

The question about acceptable geolocation errors provoked rather different responses from the different user communities. Contrary to expectations, the modellers and data assimilation people expressed more stringent requirements than the EO community. Geolocation is of primary importance when the severity of individual burns shall be assessed or when satellite data are being used in realtime to guide fire fighting measures. In the context of earth system modelling (including atmospheric chemistry, carbon cycle and dynamic vegetation modelling), the exact location of a fire is of lesser importance. However, the attribution of a fire to a specific vegetation class (and in smaller scale applications also the orography of the area in which the fire occurred) can matter. Thus, the amount and quality of metadata information that is provided with the fire data will define how well the geolocation of fire pixels must be known. Average user 
responses indicated a geolocation accuracy requirement of ideal $=1100 \mathrm{~m}$, reasonable $=2900 \mathrm{~m}$, minimum $=6000 \mathrm{~m}$.

\subsubsection{Timing}

Users want to be informed about the timing of fire events and they want to know the uncertainty of this quantity. In contrast to the acceptable geolocation error, the MOD+DA communities are prepared to accept a larger timing error (ideal $=2.3$ days, reasonable $=6.1$ days, minimum $=8.8$ days) than the EO community $(1$ day). This reflects the large proportion of carbon cycle and dynamic vegetation modellers in the MOD+DA community who are less concerned about specific atmospheric transport events. Regarding the temporal stability of the data product quality, less than $15 \%$ variability was expected in order to make reasonably accurate assessments of actual fire variability.

\subsubsection{Quality indicators}

The user responses on desired quality indicators are summarised in table 7 . The major concern for all product types is the demand to know which vegetation cover is affected by fires. Date of burn and burn severity are of particular interest to the MOD-DA community while the EO community requests more technical information about the retrieval.

Burned pixel products are primarily of interest to the EO community. These users specifically request metadata information on shadow or smoke contamination and accuracy. Furthermore, they would like to know the probability that a pixel has burned rather than a simple categorisation into burned/unburned. The number of observation days, type of fire, index of vegetation moisture content and pixel value of channel 3.9 $\mu \mathrm{m}$ were listed as additional requested information.

For burned patches products, clearly the most important information is the burned area itself, but most users also want to know the location and time of burning (start and end time) and burn severity. Some interest was also expressed for information concerning the temporal variability of burns within the grid cell. More specific information on the number and sizes of fires within a specified burned area were thought of moderate importance to most users, but ranked relatively high for users at the local scale. 


\subsubsection{Data format and product dissemination}

Among the four proposed data formats ArcGIS shape files, ASCII, HDF5, or netCDF, none stood out as being either strongly favoured or absolutely inadequate for the majority of surveyed users. As some users indicated no interest in ArcGIS or ASCII files, while others don't want to deal with HDF5 or netCDF data, it is recommended to make BA products available in at least two different formats, one from each "family". The responses to the questions about metadata specifications were rather indifferent, albeit several users indicated that the ISO19115 metadata standard with extension to raster format should be adhered to. Most users prefer access to the data via web download or ftp. There is only moderate interest in internet-based mapping or web coverage services and on-demand access is generally not regarded as an attractive option.

\subsubsection{Free-form comments}

By means of asking the users about the ideal BA product characteristics if there were no restrictions of any kind we wanted to identify the most pressing needs for sensor improvements and test if these are consistent with the relative importance of quality objectives addressed before. Remarkably, the answers were very similar. Many users think there is a lack of high resolution (geostationary) satellites with appropriate sensors for fire monitoring in terms of active fires and mapping of burn scars. These platforms should be equipped with a thermal sensor that does not saturate at typical fire temperatures in order to derive near real-time information about burn severity indices and fire radiative power.

TABLE 7

\section{Conclusion on recommendations for BA development and use}

We reviewed here the state-of-the-art sources of information related to global burned area applications. From this analysis, we could identify the wide range of end-users, covering research fields outside of the initial goal of these global BA product, mostly focussed on biosphere/atmosphere interactions, and highlighting the increasing use for land management. Based on this result, we then compiled and synthesized the requests for further BA developments for increasing both the fields of research where these data could be used, and a better accuracy when these data are already used in 
their present form. We could then provide a synthesized understanding of user requests according to their research interests, the technical limitations to cover these needs and how ongoing project had to find a balance to provide the best-we-can-do product for satisfying most users.

For most fields of research, we identified the need for an increasing length of the time-series with the most consistency across time and successive sensors, as far as errors of commission and omission are conserved or decreased compared to existing products. Fire being a stochastic event, longer time series would provide a more comprehensive fire regime at the regional level for identifying key processes for land managers (as in Moreira et al. 2011) and global process-based fire models (Thonicke et al. 2010). Longer time series will also allow to account for long-term feed backs of fire disturbances on the global budget, as for instance biomass recovery and the its related carbon sink (Chen et al. 2000, Field et al. 1999).

Increasing space and time resolution appear as a second goal to reach as we observe the significant use of active fire counts at high resolution, and should be closely linked with refinement and better accuracy on land cover products. Meeting these requirements will help to fill the gap between the status quo and the desired characteristics of fire observation data that may allow more systematic monitoring of fire activity and more accurate estimation of fire emissions. Reaching this goal will also enhance the use of this product in the increasing research community dealing with landscape management plans in fire-prone areas where fire contours are lacking. This includes landscape planning for the reduction of fire risk and subsequent impact on populations, wealth and health, as well as conservation planning.

Therefore, it is recommended that the development of new global burned area data should take into account the target requirements proposed in this study, acknowledging of course the constraints of available observing systems. This review also highlighted the importance of the uncertainty assessment that should be part of forthcoming fire emissions estimates, so that an easy access and fully comprehensible understanding of these uncertainties should be provided. This latter information started to be accounted for in global fire emissions models (Giglio et al. 2010), but still sparsely used at the regional level. We recommend data providers to highlight and describe the uncertainties of their products, and land managers working with these datasets at the regional level with pixel based information to make use of this uncertainty information to prevent any misinterpretations of the data. 
The growing topic of increasing accuracy in earth observation products, now relies more on uncertainty assessment by comparing existing datasets (Herold et al. 2008, Frei et al. 2012, Pfeifer et al. 2012), merging products to account for this uncertainty (Knorr et al. 2012) or new algorithm allowing for temporal consistency between sensors across time, leading to similar approaches used for the pre-satellite era where uncertainties are even higher (Mouillot et al. 2005, Meiyappan and Jain 2012).

\section{References}

Akagi S. K., Yokelson R. J., Wiedinmyer C., Alvarado M. J., Reid J. S., Karl T., Crounse J. D., and Wennberg P. O. 2011. Emission factors for open and domestic biomass burning for use in atmospheric models. Atmospheric Chemistry and Physics 11, 4039-4072.

Anderson, K.R., Englefield, P., Little, J.M., Reuter, G. 2009. An approach to operational forest fire growth predictions for Canada. International Journal of Wildland Fire 18 (8), 893-905

Andreae, M.O. and P. Merlet 2001, Emission of trace gases and aerosols from biomass burning Global Biogeochemical Cycles 15, 955-966.

Arca B. 2007. Evaluation of FARSITE simulator in Mesditeranean Maquis. International Journal of Wildland Fire 16(5), 563-572.

Archibald, S., Roy, D.P., van Wilgen, B.W., Scholes, R.J. 2009. What limits fire? An examination of drivers of burnt area in Southern Africa. Global Change Biology 15 (3), 613-630

Ardakani, A.S., Zoej, M.J.V., Mohammadzadeh, A., Mansourian, A. 2011. Spatial and Temporal Analysis of Fires Detected by MODIS Data in Northern Iran From 2001 to 2008. IEEE J. of Select. Top. In Appl. Earth. Obs. And Remote Sens. 4 (1): 216-225

Arora, V. K. 2003. Simulating energy and carbon fluxes over winter wheat using coupled land surface and terrestrial ecosystem models. Agricultural and Forest Meteorology $118,21-47$.

Arora, V. K. and G. J. Boer 2005. Fire as an interactive component of dynamic vegetation models, Journal of Geophysical Research 110, G02008, doi: 10.1029/2005JG000042.

Bachelet, D., J. M. Lenihan, C. Daly, R. P. Neilson, D. S. Ojima, W. J. Parton 2001. MC1: A dynamic vegetation model for estimating the distribution of vegetation and associated ecosystem fluxes of carbon, nutrients, and water. Pacific Northwest Station General Technical Report PNW-GTR-508, U.S.D.A. For. Serv., Washington, D. C.

Barbosa, P.M., Stroppiana, D., Gregoire, J.M. (1999). An assessment of vegetation fire in Africa (1981-1991): burned areas, burned biomass, and atmospheric emissions. Global Biogeochemical Cycles. 13, 933-950.

Bartalev, S.A., Egorov, V.A., Loupian, E.A., Uvarov, I.A. 2007. Multi-year circumpolar assessment of the area burnt in boreal ecosystems using SPOT-VEGETATION. International Journal of Remote Sensing 28(6), 1397-1404.

Bartholome, E. and Belward, A. S. 2005. GLC2000: A new approach to global land cover mapping from Earth observation data. International Journal of Remote Sensing 26, 1959-1977.

Bartsch, A., Balzter, H., George, C. 2009. The influence of regional surface soil moisture anomalies on forest fires in Siberia observed from satellites. Environmental Research Letters 4(4),45021. 
Biswajeet, P., Hamid, A. 2010. Forest Fire Detection and Monitoring using High Temporal MODIS and NOAA AVHRR Satellite Images in Peninsular Malaysia. Disaster Advances 3(2), 18-23.

Bond,W.J., Midgley G.F., Woodward, F.I. 2003. The importance of low atmospheric CO2 and fire in promoting the spread of grasslands and savannas. Global Change Biology 9, 973-982.

Boschetti, L., Eva, H.D., Brivio, P.A., Gregoire, J.M. 2004. Lessons to be learned from the comparison of three satellite-derived biomass burning products. Geophysical Research Letters 31(21), L21501.

Boschetti, L., Roy, D.P. 2009. Strategies for the fusion of satellite fire radiative power with burned area data for fire radiative energy derivation. Journal of Geophysical Research- Atmosphere114, D20302.

Brivio, P.A., Maggi, M., Binaghi, E., Gallo, I. 2003. Mapping burned surfaces in subSaharan Africa based on multi-temporal neural classification. International Journal of Remote Sensing 24(20), 4003-4018.

Bromley, L. 2010. Relating violence to MODIS fire detections in Darfur Sudan. International Journal of Remote Sensing 31(9), 2277-2292.

Carmona-Moreno, C., Belward, A., Malingreau, J.-P., Hartley, A., Garcia-Alegre, M., Antonovskiy, M., Buchshtaber, V., and Pivovarov, V. 2005. Characterizing interannual variations in global fire calendar using data from Earth observing satellites. Global Change Biology 11, 1537-1555.

Chang, D., Song, Y. 2009. Comparison of L3JRC and MODIS global burned area products from 2000 to 2007. Journal of Geophysical Research-Atmosphere114, D16106.

Chen, J., Chen, W., Liu, J., Cihlar J., Gray S. 2000. Annual carbon balance of Canada's forests during 1895-1996. Global Biochemical Cycles 14, 839-849.

Chuvieco, E., \& Congalton, R.G. 1988. Mapping and inventory of forest fires from digital processing of TM data. Geocarto International 4, 41-53.

Chuvieco, E., Aguado, I., Yebra, M., Nieto, H., Salas, J., Martin, M.P., Vilar, L., Martinez, J., Martin, S., Ibarra, P., de la Riva, J., Baeza, J., Rodriguez, F., Molina, J.R., Herrera, M.A., Zamora, R. 2010. Development of a framework for fire risk assessment using remote sensing and geographic information system technologies. Ecological Modelling 221 (1), 46-58.

Ciais, P., Dolman, A.J., Dargaville, R., Barrie, L., Bombelli, A., Butler, J., Canadell, P., Moriyama, T. 2010. Geo Carbon Strategy Geo Secretariat Geneva/FAO, Rome, 48 pp.

Cox, P. M. 2001. Description of the TRIFFID dynamic global vegetation model, Tech. Note 24, 16 pp., Hadley Cent., Bracknell, U. K.

Crutzen P.J., Heidt L.E., Krasnec J.P., Pollock W.H., Seiler W. 1979. Biomass burning as a source of atmospheric gases $\mathrm{CO}, \mathrm{H} 2, \mathrm{~N} 2 \mathrm{O}, \mathrm{CH} 3 \mathrm{Cl}$ and $\mathrm{COS}$. Nature 282(5736), 253-256.

Crutzen, P.J., Andreae, M.O. 1990. Biomass burning in the tropics: impact on atmospheric chemistry and biogeochemical cycles. Science 250, 1669-1677.

Dai, Y., X. B. Zeng, R. E. Dickenson, I. Baker, G. B. Bonan, M. G. Bosilovich, A. S. Denning, P.A. Dirmeyer, P. R. Houser (2003), The Common Land Model, Bulletin of the American Meteorological Society 84, 1013- 1023.

Davies, D.K., Ilavajhala, S., Wong, M.M., Justice, C.O. 2009. Fire Information for Resource Management System: Archiving and Distributing MODIS Active Fire Data. IEEE Transactions in Geosciences and Remote Sensing 47(1), 72-79.

De Klerk, H. 2008. A pragmatic assessment of the usefulness of the MODIS (Terra and Aqua) 1-km active fire (MOD14A2 and MYD14A2) products for mapping fires in the fynbos biome. International Journal of Wildland Fire. 17(2), 166-178.

Dempewolf, J., Trigg, S., DeFries, R.S., Eby, S. 2007. Burned-area mapping of the Serengeti-Mara region using MODIS reflectance data. IEEE Geoscience Remote Sensing Letters 4 (2), 312-316. 
Devineau, J.L., Fournier, A., Nignan, S. 2010. Savanna fire regimes assessment with MODIS fire data: Their relationship to land cover and plant species distribution in western Burkina Faso (West Africa). Journal of Arid Environment 74(9), 1092-1101.

Diagne, M., Drame, M., Ferrao, C., Marchetti, P.G., Pinto, S., Rivolta, G. 2010. Multisource Data Integration for Fire Risk Management: The Local Test of a Global Approach. IEEE Geosciences and Remote Sensing Letters 7(1), 93-97.

Duguy B., Alloza J.A., Roder A., Vallejo R., Pastor F. 2007. Modelling the effects of landscape fuel treatment on fire growth and behaviour in a Mediterranean landscape (eastern Spain). International Journal of Wildland Fire 16(5), 619-632.

Duncan, B.N., Bey, I., Chin, M., Mickley, L.J., Fairlie, T.D., Martin, R.V., Matsueda, H. 2003. Indonesian wildfires of 1997: Impact on tropospheric chemistry. Journal of Geophysical Research-Atmosphere 108(D15), 4458.

Duncan, B.N., Martin, R.V., Staudt, A.C., Yevich, R., Logan, J.A. 2003. Interannual and seasonal variability of biomass burning emissions constrained by satellite observations. Journal of Geophysical Research-Atmosphere 108 (D2), 4100.

Dwyer, E., Pinnock, S., Gregoire, J.M., Pereira J.M.C. (2000). Global spatial and temporal distribution of vegetation fire as determined from satellite observations. International Journal of Remote Sensing 21, 1289-1302.

Eckmann, T.C., Roberts, D.A., Still, C.J. 2008. Using multiple endmember spectral mixture analysis to retrieve subpixel fire properties from MODIS. Remote Sensing of Environment 112(10), 3773-3783.

Ellicott, E., Vermote, E., Giglio, L., Roberts, G. 2009. Estimating biomass consumed from fire using MODIS FRE. Geophysical Research Letters 36, L13401.

Eva, H., Lambin, E.F, 1998a. Burnt area mapping in Central Africa using ATSR data. International Journal of Remote Sensing 19, 3473-3497.

Eva, H., Lambin, E.F. 1998b. Remote sensing of biomass burning in tropical regions sampling issues and multisensor approach. Remote Sensing of Environment 64, 292-315.

FAO 2001. Global forest fire assessment, 1990-2000, (Rome) Italy.

Field C.B., Randerson J.T., Malmstrom C.M. 1995. Global net primary production combining ecology and remote sensing. Remote Sensing of Environment 51(1),7488.

Field C.B. and Fung I.Y. 1999. Biogeochemical Cycles - the not so big US carbon sink. Science 285(5427), 544-545.

Fraser R.H., Hall R.J., La,dry R., Lynham T., Raymond D., Lee B., Li Z. 2004. Validation and calibration of Canada-wide coarse resolution satellite burned area maps. Photogrammetric engineering and remote sensing 70(4), 451-460.

Fraser R.H., Li Z., Landry R. 2000. SPOT vegetation for characterizing boreal forest fires. International Journal of Remote Sensing 21(18), 3525-3532.

Frei A., Tedesco M., Lee S., Foster J., Hall D.K., Kelly R., Robinson D.A 2012. a review of global satellite derived snow products. Advances in Space Research 50(8), 10071029.

Furyaev, V.V. (1985). The use of aerospace imagery to examine and assess the consequences of forest fires. Soviet Journal of Remote Sensing 4, 773-782.

GCOS, 2010. Implementation Plan for the Global Observing System for Climate in Support of the UNFCCC (2010 Update) (GCOS-138). August 2010. http://www.wmo.int/pages/prog/gcos/Publications/gcos-138.pdf. last retrieval 23/07/2012

GCOS, 2011. Systematic Observation Requirements for Satellite-Based Products for Climate. 2011 Update (GCOS-154). Supplemental details to the satellite-based component of the "Implementation Plan for the Global Observing System for Climate in Support of the UNFCCC (2010 Update)". December 2011, http://www.wmo.int/pages/prog/gcos/Publications/gcos-154.pdf, last retrieval 23/07/2012 
GTOS, 2009. Assessment of the Status of the Development of the Standards for the Terrestrial Essential Climate Variables - Fire Disturbance. Rome. $\mathrm{ftp} / / / \mathrm{ftp}$. fao.org/docrep/fao/012/i1239e/i1239e00.pdf, last retrieval 23/07/2012.Generoso, S., Breon, F.M., Balkanski, Y., Boucher, O., Schulz, M. 2003. Improving the seasonal cycle and interannual variations of biomass burning aerosol sources. Atm. Chem. Phys. 3: 1211-1222

Gerard F., Plummer S., Wadsworth R., Sanfeliu A.F., Lliffe L., Baltzer H., Wyatt B. 2003. Forest fire scar detection in the boreal forest with mulmtitemporal SPOTVEGETATION data. IEEE Transactions on Geosciences and Remote Sensing 41(11), 2575-2585.

Generoso S. Breon F.M., Balkanski Y., Boucher O., Schulz M. 2003. Improving the seasonal cycle and interannual variations of biomass burning aerosol sources. Atmospheric Chemistry and Physics 3, 1211-1222.

Giglio. L., Loboda, T., Roy, D.P., Quayle, B., Justice, C.O. 2009. An active-fire based burned area mapping algorithm for the MODIS sensor. Remote Sensing of Environment 113(2), 408-420.

Giglio, L., Randerson, J.T., van der Werf, G.R., Kasibhatla, P.S., Collatz, G.J., Morton, D.C., DeFries, R.S. 2010. Assessing variability and long-term trends in burned area by merging multiple satellite fire products. Biogeosciences 7(3), 1171-1186.

Giglio, L., van der Werf, G.R., Randerson, J.T., Collatz, G.J., Kasibhatla, P. 2006. Global estimation of burned area using MODIS active fire observations. Atmospheric Chemistry and Physics 6, 957-974.

GTOS T13, Fire Disturbance, 2009. Assessment of the status of the development of the standards for the Terrestrial Essential Climate Variables, Rome, http://www.fao.org/gtos/doc/ECVs/T13/T13.pdf

Hao W.M. and Liu M.H. 1994. Spatial and temporal distribution of tropical biomass burning. Global Biogeochemical Cycles 8(4), 495-503.

Harwell E.E. 2000. Remote sensibilities: discourses of technology and the making of Indonesia's natural disaster. Development and Change 31(1), 307-340.

Hawbaker, T.J., Radeloff, V.C., Syphard, A.D., Zhu, Z.L., Stewart, S.I. 2008. Detection rates of the MODIS active fire product in the United States. Remote Sensing of Environment 112(5), 2656-2664.

Herold, M., Mayaux, P. et al. 2008. Some challenges in global land cover mapping: An assessment of agreement and accuracy in existing $1 \mathrm{~km}$ datasets. Remote Sensing of Environment 12(5), 2538-2556.

IPCC Forth Assessment Report (AR4), 2007. Working Group I - III Reports, The AR4 Synthesis http://www.ipcc.ch/publications and data/publications and data reports.shtml

Isaev A.S., Korovin G.N., Bartalev S.A., Ershov D.V., Janetos A., Kasischke E.S., Shugart H.H., French N.H.F., Orlick B.E., Murphy T.L. 2002 Using remote sensing to assess Russian forest fire carbon emissions. Climatic Change 55(1-2), 235-249.

Justice, C.O. et al. - White Paper on a NASA Fire ESDR. http://landportal.gsfc.nasa.gov/Documents/ESDR/Fire Justice whitepaper.pdf

Kaiser, J.W., M. Suttie, J. Flemming, J.-J. Morcrette, O. Boucher and M.G. Schultz.2009. Global Real-time Fire Emission Estimates Based on Space-borne Fire Radiative Power Observations, Proceedings of the Internal Radiation Symposium, San Diego, CA, USA, August 2008.

Kasischke E.S. and French N.H.F. 1995. Locating and estimating the aeral extent of wildfires in Alaskan boreal forests using multiple season AVHRR NDVI composite data. Remote Sensing of Environment 51(2), 263-275.

Kasischke, ES., Loboda, T., Giglio, L., French, NHF, Hoy EE., de Jong, B., Riano, D. 2011. Quantifying burned area for North American forests: Implications for direct reduction of carbon stocks. Journal of Geophysical Research-Biogeosciences 116, G04003. 
Keane, R.E., Cary G.J., Davies I.D., Flannigan M.D., Gardner R.H., LAvorel S., Lenihan J.M., Li C. Rupp T.S. 2004. A classification of landscape fire succession models: spatial simulations of fire and vegetation dynamics. Ecological Modelling 179(1), 327.

Keane, R.E., Arno, S.F., Brown, J.K., 1989. USDA ForestService Intermountain Research Station General Technical Report INT-266FIRESUM - An ecological Process Model for Fire Succession in Western Conifer Forests, September.

Korontzi, S., Roy, D.P., Justice, C.O., Ward, D.E. 2004. Modeling and sensitivity analysis of fire emissions in southern Africa during SAFARI 2000. Remote Sensing of Environment 92(2),255-275.

Knorr W. Lehsten V., Arneth A. 2012. Determinants and predictability of global wildfire emissions. Atmospheric Chemistry and Physics 12(15), 6845-6861.

Krinner, G., N. Viovy, N. de Noblet-Ducoudré, J. Ogée, J. Polcher, P. Friedlingstein, P. Ciais, S. Sitch, and I. C. Prentice 2005. A dynamic global vegetation model for studies of the coupled atmosphere-biosphere system, Global Biogeochemical Cycles 19, GB1015.

Kucharik, C. J., J. A. Foley, C. Delire, V. A. Fisher, M. T. Coe, J. D. Lenters, C. YoungMolling, and N. Ramankutty 2000. Testing the performance of a dynamic global ecosystem model: Water balance, carbon balance, and vegetation structure, Global Biogeochemical Cycles 14, 795-825.

Kushida, K. 2010. Detection of Active Wildland Fires Using Multitemporal MODIS Images. IEEE Geosciences and Remote Sensing Letters 7(2),301-305.

Lawrence, P. J., and T. N. Chase 2007. Representing a new MODIS consistent land surface in the Community Land Model (CLM 3.0). Journal of Geophysical Research 112, G01023.

Le Page, Y., Pereira, J.M.C., Trigo, R., da Camara, C., Oom, D., Mota, B. 2008. Global fire activity patterns (1996-2006) and climatic influence: an analysis using the World Fire Atlas. Atmospheric Chemistry and Physics 8(7),1911-1924.

Lenihan, J. M., and R. P. Neilson 1998, Simulating broad-scale fire severity in a dynamic global vegetation model. Northwest Sciences 72, 91-103.

Levis, S., G. B. Bonan, M. Vertenstein, and K. W. Oleson 2004, The Community Land Model's dynamic global vegetation model (CLM-DGVM): Technical description and user's guide. NCAR Tech. Note TN-459_IA, Terrestrial Sciences Section, Boulder, Colorado

Loboda, T., O'Neal, K.J., Csiszar, I. 2007. Regionally adaptable dNBR-based algorithm for burned area mapping from MODIS data. Remote Sensing of Environment 109(4), 429-442.

Loboda, T.V., Csiszar, I.A. 2007. Reconstruction of fire spread within wildland fire events in Northern Eurasia from the MODIS active fire product. Global and Planetary Change 56, 258-273.

Loboda, TV, Hoy, EE Giglio, L., Kasischke, ES 2011. Mapping burned area in Alaska using MODIS data: a data limitations-driven modification to the regional burned area algorithm . International Journal of Wildland Fire 20 (4), 487-496.

McCallum, I., Obersteiner, M. et al. 2006. A spatial comparison of four satellite derived 1 $\mathrm{km}$ global land cover datasets. International Journal of Applied Earth Observation and Geoinformation 8(4), 246-255.

Meiyappan P., Jain A.K. Three distinct global estimates of historical land cover change and land use conversions for over 200 years. Frontiers of Earth Sciences 6(2), 122139.

Miettinen, J., Langner, A., Siegert, F. 2007. Burnt area estimation for the year 2005 in Borneo using multi-resolution satellite imagery. International Journal of Wildland Fire 16(1), 45-53.

Mieville A. Granier C., Liousse C., Guillaume B., Mouillot F., Lamarque J.F., Gregoire J.M., Petron G. 2010. Emissions of gases and particles from biomass burning 
during the 20th century using satellite data and an historical reconstruction. Atmospheric Environment 44(11), 1469-1477.

Milne, A.K. 1986. The use of remote sensing in mapping and monitoring vegetational change associated with bushfire events in Eastern Australia. Geocarto International 1, 25-32.

Moorcroft, P. R., G. C. Hurtt, and S. W. Pacala 2001. A method for scaling vegetation dynamics: The ecosystem demography model (ED), Ecological Monographs 71, 557- 586.

Moreira F., Viedma O., Arianoutsou M., Curt T., Koutsias N., Rigolot E., Barbati A., Corona P., Vaz P., Xanthopoulos G., Mouillot F., Bilgili E. 2011. Landscape-wildfire interactions in southern Europe: Implications for landscape management. Journal of Environmental Management 92(10): 2389-2402.

Morton, D.C., DeFries, R.S., Nagol, J., Souza, C.M., Kasischke, E.S., Hurtt, G.C., Dubayah, R. 2011. Mapping canopy damage from understory fires in Amazon forests using annual time series of Landsat and MODIS data. Remote Sensing of Environment 115(7):1706-1720.

Mouillot F. and Field 2005. Fire history and the global carbon budget: a 1x1 degree fire history reconstruction for the $20^{\text {th }}$ century. Global Change Biology 11(3),398-420.

Mouillot, F., Narasimha, A., Balkanski Y., Lamarque J.F., Field, C.B. 2006. Global carbon emissions from biomass burning in the 20th century. Geophysical Research Letters 33(1), L01801.

NASA, 2011. White Paper on a NASA Fire ESDR. http://landportal.gsfc.nasa.gov/Documents/ESDR/Fire_Justice_whitepaper.pdf. last retrieval 23/07/2012.

Oleson, K. W., D. M. Lawrence, G. B. Bonan, M. G. Flanner, E. Kluzek, P. J. Lawrence, S. Levis, S. C. Swenson, P. E. Thornton, A. Dai, M. Decker, R., Dickinson, J. Feddema, C. L. Heald, F. Hoffman, J. F. Lamarque, N. Mahowald, G.-Y. Niu, T. Qian, J. Randerson, S. Running, K. Sakaguchi, A. Slater, R. Stockli, A. Wang, Z.-L. Yang, X. Zeng, and X. Zeng 2010. Technical description of version 4.0 of the Community Land Model, NCAR Tech. Note NCAR/TN-478+STR, Terrestrial Sciences Section, Boulder, Colorado.

Palacios-Orueta A., Chuvieco E., Parra A., Carmona-Moreno C. 2005. Biomass burning emissions: a Review of models using remote sensing data. Environemental Monitoring and Assessment 104(1-3),189-209.

Pausas, J. G., Bradstock, R. A., Keith, D. A., and Keeley, J. E. 2004. Plant functional traits in relation to fire in crown-fire ecosystems. Ecology 85, 1085-1100.

Peng, G.X., Shen, W., Hu, D.Y., Li, J., Chen, Y.H. 2008. Method to identify forest fire based on smoke plumes mask by using MODIS data. Journal of Infrared and Millimeter Waves 27(3), 185-189.

Pereira J.M.C 2003. Remote sensing of burned area in tropical savannas. International Journal of Wildland Fire 12, 259-270.

Pereira J.M.C., Vasconcelos M.J.P., Sousa A.M. 2000. A rule based system for burned area mapping in temperate and tropical regions using NOAA/AVHRR imagery. in "biomass burning and its inter-relationship with the climate system" Eds Innes J.L., Beniston M., Verstraete M.M. pp215-232.

Pfeifer M., Disney M., Quaife T., Marchant R., 2012. Terrestrial ecosystems from space: a review of earth observation products for macroecology applications. Global Ecology and Biogeography 21, 603-624.

Plummer, S., O. Arino, F. Ranera, K. Tansey, J. Chen, G. Dedieu, H. Eva, et al. 2007. An update on the Globcarbon initiative: multi-sensor estimation of global biophysical products for global terrestrial carbon studies. Proceedings paper. http://eprints.ucl.ac.uk/179082/.

Plummer, S., Olivier A., Muriel S., and Will S. 2006. "Establishing A Earth Observation Product Service For The Terrestrial Carbon Community: The Globcarbon Initiative." 
Mitigation and Adaptation Strategies for Global Change 11 (1): 97-111. doi:10.1007/s11027-006-1012-8.

Plummer, S. 2009. The ESA Climate Change Initiative - Description, issue 1, revision 0 30/09/09 http://earth.esa.int/workshops/esa cci/ESA CCI Description.pdf

Potter C.S., Randerson J.T., Field C.B., Matson P.A., Vitousek P.M., Mooney H.A., Klooster S.A, 1993. Terrestrial ecosystem production: a process model based on global satellite and surface data. Global Biogeochemical Cycles 7(4), 811-841.

Potter CS., Davidson E.A., Klooster S.A., Nepstad D.C., DeNegreiros G.H., Brooks V. 1998. Regional application of an ecosystem production model for studies of biogeochemistry in Brazilian Amazonia. Global Change Biology 4(3), 315-333.

Pu R., Gong P., Li Z. Scarborough J. 2004. A dynamic algorithm for wildfire mapping with NOAA/AVHRR data. International Journal of Wildland Fire 13 (3), 275-285.

Pu, R.L., Li, Z.Q., Gong, P., Csiszar, I., Fraser, R., Hao, W.M., Kondragunta, S., Weng, F,Z. 2007. Development and analysis of a 12-year daily $1-\mathrm{km}$ forest fire dataset across North America from NOAA/AVHRR data. Remote Sensing of Environment 108(2), 198-208.

Punia, M., Nautiyal, V.P., Kant, Y. 2008. Identifying biomass burned patches of agriculture residue using satellite remote sensing data. Current Sciences 94(9), 1185-1190.

Radke L.F., Stith J.L., Hegg D.A., Hobbs P.V. 1978. Airborne studies of particles and gases from forest fires. Journal of Air Pollution Control Association 28(1),30-34.

Redo D., Milington A.C., Hinderry D. 2011. Deforestation dynamics and policy changes in Bolivia's post neoliberal era. Land Use Policy 28(1), 227-241.

Reid J.S., Hyer E.J., Prins E.M., Westphal D.L., Zhang J.L., Wang J., Christopher S.A., Curtis C.A., Schmidt C.C., Eleutorio D.P., Richardson K.A., Hoffman J.P. 2009. Global monitoring and forecasting of biomass burning smoke: description of and lessons from the fire locating and modelling of burning emissions (FLMABE) program. IEEE Journal of Selected Topics in Applied Earth Observation and Remote Sensing 2(3), 144-162.

Ressl R. Lopez G., Cruz I., Colditz R.R., Schmidt M., Ressl S., Jimenez R. 2009. Operational active fire mapping and burnt area identification applicable to Mexican Nature protection areas using MODIS and NOWW AVHRR direct readout data. Remote Sensing of Environment 113(6), 1113-1126.

Robbins, A.M.J., Eckelmann, C.M., Quinones, M. 2008. Forest Fires in the Insular Caribbean. Ambio 37, 528-534.

Roy D.P., Giglio L., Kendall J.D., Justice C.O.1999. Multi-temporal active-fire based burn scar detection algorithm. International Journal of Remote Sensing 20(5), 1031-1038.

Roy, D.P., Boschetti, L., Justice, C.O., Ju, J. 2008. The collection 5 MODIS burned area product - Global evaluation by comparison with the MODIS active fire product. Remote Sensing of Environment 112(9),3690-3707.

Roy, D.P., Frost, P.G.H., Justice, C.O., Landmann, T., Le Roux, J.L., Gumbo, K., Makungwa, S., Dunham, K., Du Toit, R., Mhwandagara, K., Zacarias, A., Tacheba, B., Dube, O.P., Pereira, J.M.C., Mushove, P., Morisette, J.T., Vannan, S.K.S., Davies, D. 2005a. The Southern Africa Fire Network (SAFNet) regional burned-area product-validation protocol. International Journal of Remote Sensing 26(19), 42654292.

Roy, D.P., Jin, Y., Lewis, P.E., Justice, C.O. 2005b. Prototyping a global algorithm for systematic fire-affected area mapping using MODIS time series data. Remote Sensing of Environment 97(2), 137-162.

Roy, D.P., Trigg, S.N., Bhima, R., Brockett, B.H., Dube, O.P., Frost, P., Govender, N., Landmann, T., Le Roux, J., Lepono, T., Macuacua, J., Mbow, C., Mhwandangara, K.L., Mosepele, B., Mutanga, O., Neo-Mahupeleng, G., Norman, M., Virgilo, S. 2006. The utility of satellite fire product accuracy information - Perspectives and 
recommendations from the southern Africa fire network. IEEE Transactions in Geosciences and Remote Sensing 44 (7), 1928-1930.

Running, S.W. and E.R. Hunt, Jr. 1993. Generalization of a forest ecosystem process model for other biomes, BIOME-BGC, and an application for global-scale models. Pp. 141-158 In J.R. Ehleringer and C.B. Field (eds.) Scaling Physiological Processes: Leaf to Globe. Academic Press, Inc. New York

Sa, A.C.L., Pereira, J.M.C., Gardner, R.H. 2007. Analysis of the relationship between spatial pattern and spectral detectability of areas burned in southern Africa using satellite data. International Journal of Remote Sensing 28(16), 3583-3601.

Sato, H., A. Itoh, and T. Kohyama 2007. SEIB-DGVM: a new Dynamic Global Vegetation Model using a spatially explicit individual-based approach. Ecological Modelling 200, 279-307.

Schroeder,W., Ruminski, M., Csiszar, I., Giglio, L., Prins, E., Schmidt, C., Morisette, J. 2008. Validation analyses of an operational fire monitoring product: The Hazard Mapping System. International Journal of Remote Sensing 29(20), 6059-6066.

Schultz M.G., Heil A., Hoelzemann J.J., Spessa A., Thonicke K., Goldammer J.G., Held A.C., Pereira J.M.C., Van Het Bolscher M. 2008 Global wildland fire emissions from 1960 to 2000. Global Biogeochemical Cycles 22(2), GB2002.

Schultz, M.G. 2002. On the use of ATSR fire count data to estimate the seasonal and interannual variability of vegetation fire emissions. Atmospheric Chemistry and Physics 2, 387-395.

Seiler, W., Crutzen, P.J. 1980. Estimates of gross and net fluxes of carbon between the biosphere and the atmosphere from biomass burning. Climatic Change 2, 207-247.

Simon, M., Plummer, S., Fierens, F., Hoelzemann, J.J., Arino, O. 2004. Burnt area detection at global scale using ATSR-2: The GLOBSCAR products and their qualification. Journal of Geophysical Research-Atmosphere 109 (D14), D14S02.

Sitch, S., B. Smith, I. C. Prentice, A. Arneth, A. Bondeau, W. Cramer, J. O. Kaplan, S. levis, W. Lucht, M. T. Sykes, K. Thonicke, S. Venevsky, 2003. Evaluation of ecosystem dynamics, plant geography and terrestrial carbon cycling in the LPJ dynamic global vegetation model. Global Change Biology 9, 161-185.

Smith, R.B., \& Woodgate, P.W. 1985. Appraisal of fire damage and inventory for timber salvage by remote sensing in mountain ash forests in Victoria. Australian Forestry 48, 252-263.

Smith, B., Prentice, I.C., Sykes M.T. 2001. Representation of vegetation dynamics in the modeling of terrestrial ecosystems: comparing two contrasting approaches within European climate space. Global Ecology and Biogeography 10, 621-637.

Stroppiana D., Gregoire J.M., Pereira J.M.C. 2002. The use of SPOT-VEGETATION data in a classification tree approach for burbnt area mapping in Australia savanna. International Journal of Remote Sensing 24(10), 2131-2151.

Sukhinin, A. I., French, N. H. F., Kasischke, E. S., Hewson, J. H., Soja, A. J., Csiszar, I. A., Hyer, E. J., Loboda, T., Conrad, S. G., Romasko, V. I., Pavlichenko, E. A., Miskiv, S. I., and Slinkina, O. A. 2004. AVHRR-based mapping of fires in Russia: New products for fire management and carbon cycle studies. Remote Sensing of Environment 93, 546-564.

Tansey, K., Beston, J., Hoscilo, A., Page, S.E., Hernandez, C.U.P. 2008. Relationship between MODIS fire hot spot count and burned area in a degraded tropical peat swamp forest in Central Kalimantan Indonesia. Journal of Geophysical ResearchAtmosphere 113(D23), D23112.

Tansey, K., Jean-Marie G., Pierre Defourny, Roland Leigh, Jean-François Pekel, Eric van Bogaert, and Etienne Bartholomé. 2008. "A new, global, multi-annual (2000-2007) burnt area product at $1 \mathrm{~km}$ resolution." Geophysical Research Letters 35 (1), GL031567.

Tansey, K., Jean-Marie Grégoire, Daniela Stroppiana, Adélia Sousa, João Silva, José M. C. Pereira, Luigi Boschetti, et al. 2004. "Vegetation burning in the year 2000: Global 
burned area estimates from SPOT VEGETATION data." Journal of Geophysical Research 109, 22.

Thonicke, K., A. Spessa, I. C. Prentice, S. P. Harrison, L. Dong, and C. Carmona-Moreno. 2010. "The influence of vegetation, fire spread and fire behaviour on biomass burning and trace gas emissions: results from a process-based model." Biogeosciences 7 (6), 1991-2011.

Thonicke, K., S. Venevsky, S. Sitch, and W. Cramer, 2001. The role of fire disturbance for global vegetation dynamics: Coupling fire into a Dynamic Global Vegetation Model, Global Ecology and Biogeography 10, 661- 677.

Townshend, J.R., Latham, J., Arino, O., Balstad, R., Belward, A., Conant, R., Elvidge, C., Feuquay, J., El Hadani, D., Herold, M., Janetos, A., Justice, C.O., Liu Jiyuan, Loveland, T., Nachtergaele, F., Ojima, D., Maiden, M., Palazzo, F., Schmullius, C., Sessa, R., Singh, A., Tschirley, J. and Yamamoto, H. 2008. Integrated Global Observations of the Land: an IGOS-P Theme. IGOL Report No. 8, GTOS 54

Trigg, S.N., Roy, D.P. 2007. A focus group study of factors that promote and constrain the use of satellite-derived fire products by resource managers in southern Africa. Journal of Environmental Management 82(1), 95-110.

Van der Werf G.R., Randerson J.T., Collatz G.J., Giglio L. 2003. Carbon emissions from fires in tropical and subtropical ecosystems. Global Change Biology 9(4), 547-562.

Van der Werf, G.R., Morton, D.C., DeFries, R.S., Giglio, L., Randerson, J.T., Collatz, G.J., Kasibhatla, P.S. 2009. Estimates of fire emissions from an active deforestation region in the southern Amazon based on satellite data and biogeochemical modelling. Biogeosciences 6(2), 235-249.

Van der Werf, G.R., Randerson, J.T., Giglio, L., Collatz, G.J., Kasibhatla, P.S., Arellano, A.F. 2006. Interannual variability in global biomass burning emissions from 1997 to 2004. Atmospheric Chemistry and Physics 6, 3423-3441.

Van der Werf, G. R., J. T. Randerson, L.Giglio, G. J. Collatz, P. S. Kasibhatla, D. C. Morton and R. S. DeFries, 2010. The improved Global Fire Emissions Database (GFED) version 3: contribution of savanna, forest, deforestation, and peat fires to the global fire emissions budget. Geophysical Research Abstracts 12, pp 13010, Vienna (Austria).

Venevsky, S., K. Thonicke, S. Sitch, and W. Cramer, 2002, Simulating fire regimes in human-dominated ecosystems: Iberian Peninsula case study. Global Change Biology 8, 984- 998.

Wang, W.L., Dungan, J., Hashimoto, H., Michaelis, A.R., Milesi, C., Ichii, K., Nemani, R.R. 2011. Diagnosing and assessing uncertainties of terrestrial ecosystem models in a multimodel ensemble experiment: 2. Carbon balance. Global Change Biology 17(3), 1367-1378.

Woodward, F. I. and M. R. Lomas, 2004. Vegetation dynamics-simulation responses to climatic change. Biological Reviews 79, 643-670.

Woodward, F.I., Smith, T.M., Emanuel, W.R. 1995. A global land primary productivity and phytogeography model. Global Biogeochemical Cycles 9, 471-490.

Wright, S.J., Sanchez-Azofeifa, G.A., Portillo-Quintero, C., Davies, D. 2007. Poverty and corruption compromise tropical forest reserves. Ecological Applications 17(5),12591266.

Zeng, X. D. 2010. Evaluating the dependence of vegetation on climate in an improved dynamic global vegetation model. Advances in Atmospheric Sciences 27, 977-991.

Zhang, X.Y., Kondragunta, S., Schmidt, C., Kogan, F. 2008. Near real time monitoring of biomass burning particulate emissions (PM2.5) across contiguous United States using multiple satellite instruments. Atmospheric Environment 42(29), 6959-6972.

Zhang Y.H., Wooster M.J., Tutubalina O., Perry G.L.W. 2003. Monthly burned area and forest fire carbon emission estimates for the Russian Federation from SPOT GVT. Remote Sensing Of Environment 87(1), 1-15. 
Figure Caption

Figure 1: Number of papers references in isiweb using global BA information classified by input product name (a), and using active fire detection (MODIS MOD or MYD product, and ATSR)

Figure 2 - Yearly percentage of peer reviewed papers classified by topic

Figure 3 - Yearly percentage of peer reviewed papers using BA products for global or continental

Figure 4 - Regional distribution of questionnaire responses (a) and area of expertise of the participants (b). A total of 47 replies were received.

Figure 5 - Requested product characteristics for BA products - Users were asked to assess usefulness of each product type on a scale from 0 (not useful) to 10 (maximum usefulness). Vertical lines denote the range of answers provided 
Figure 1

a)

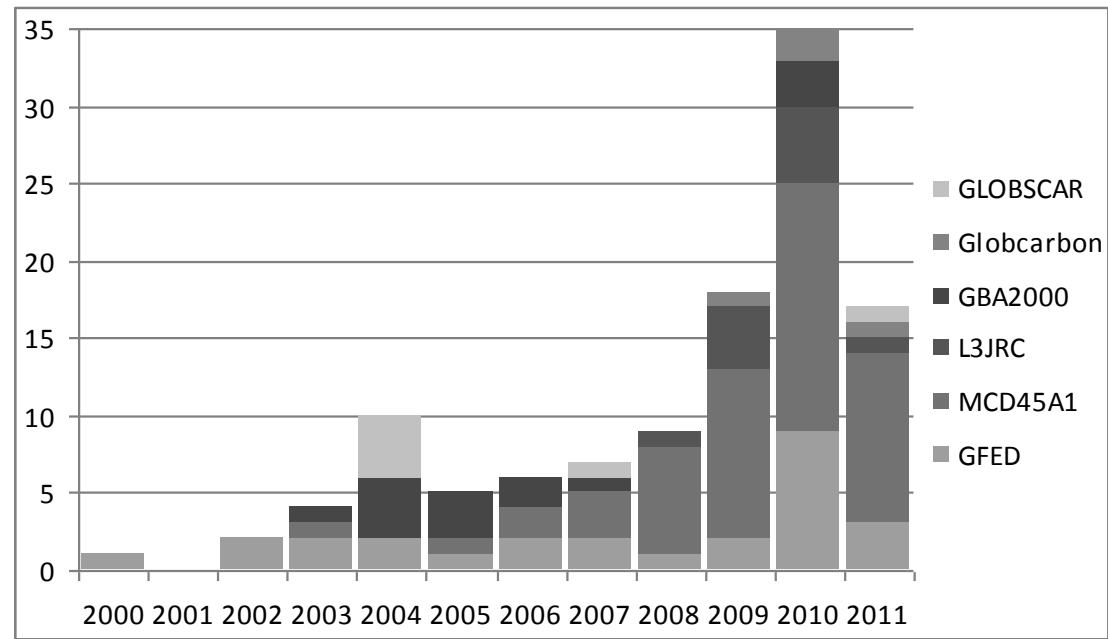

b)

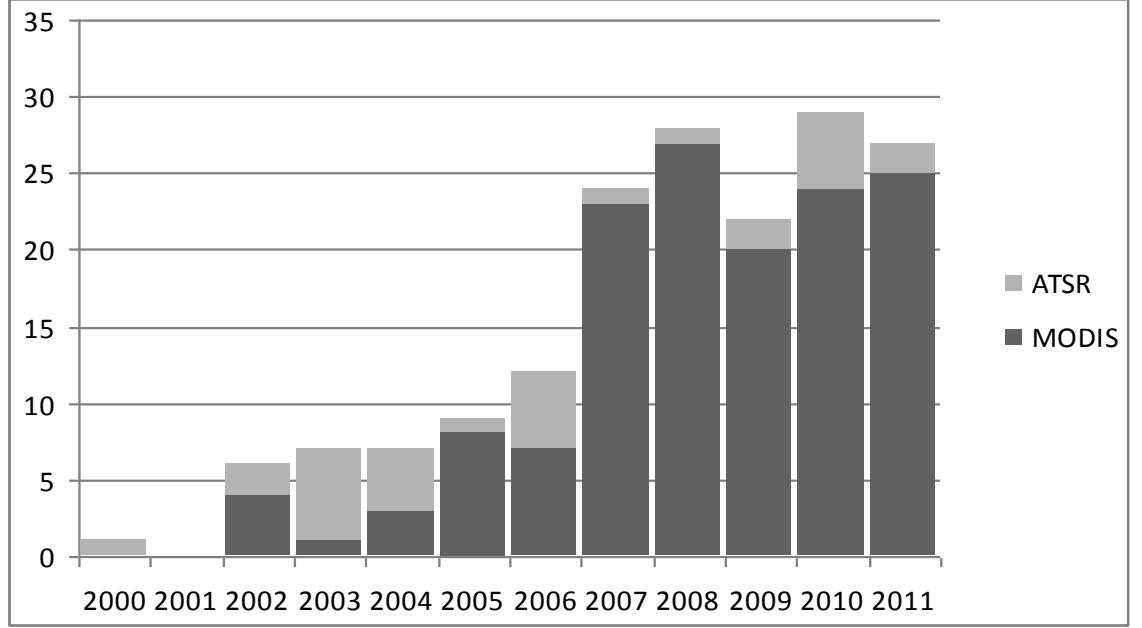


Figure 2

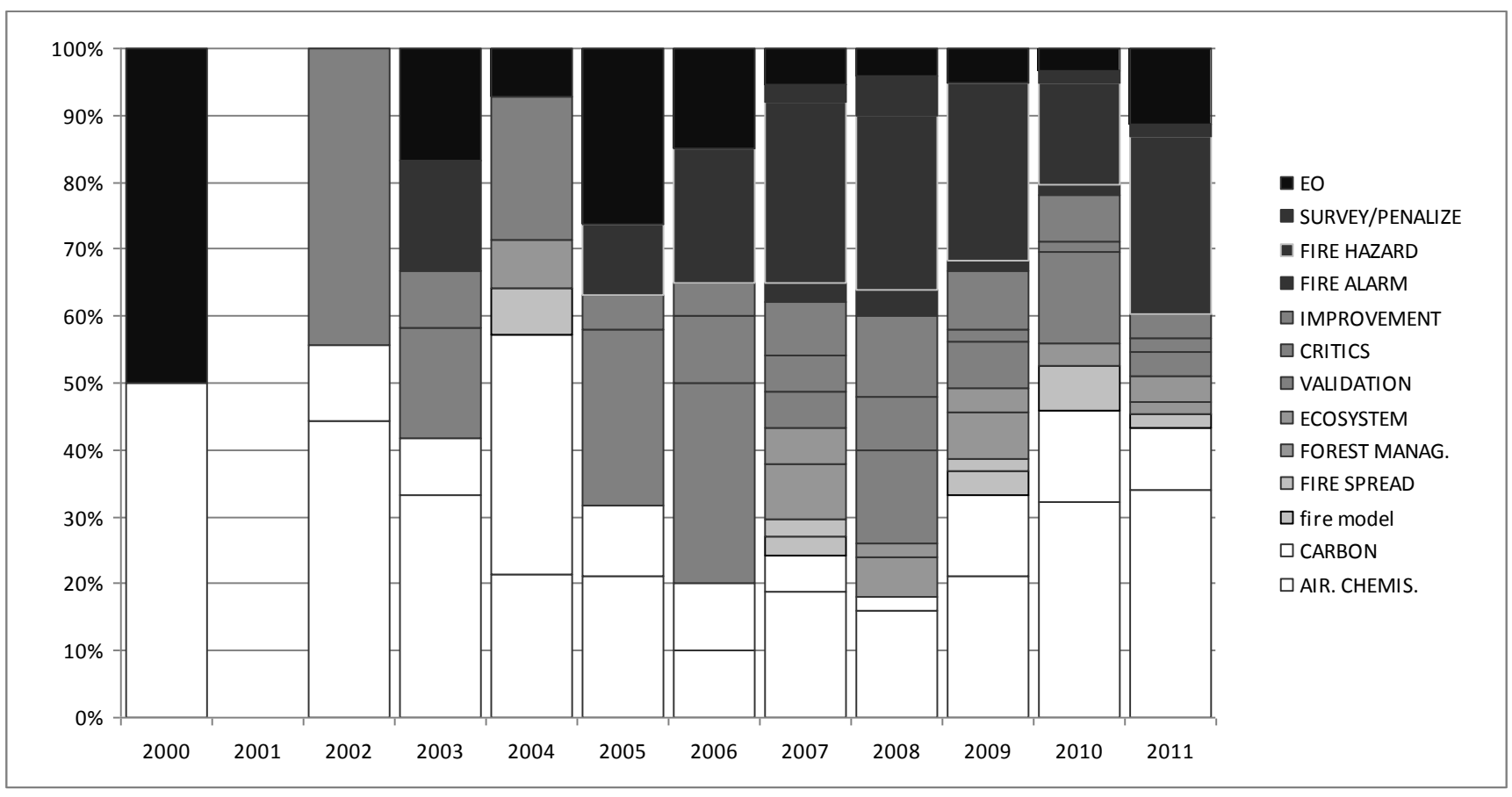


Figure 3

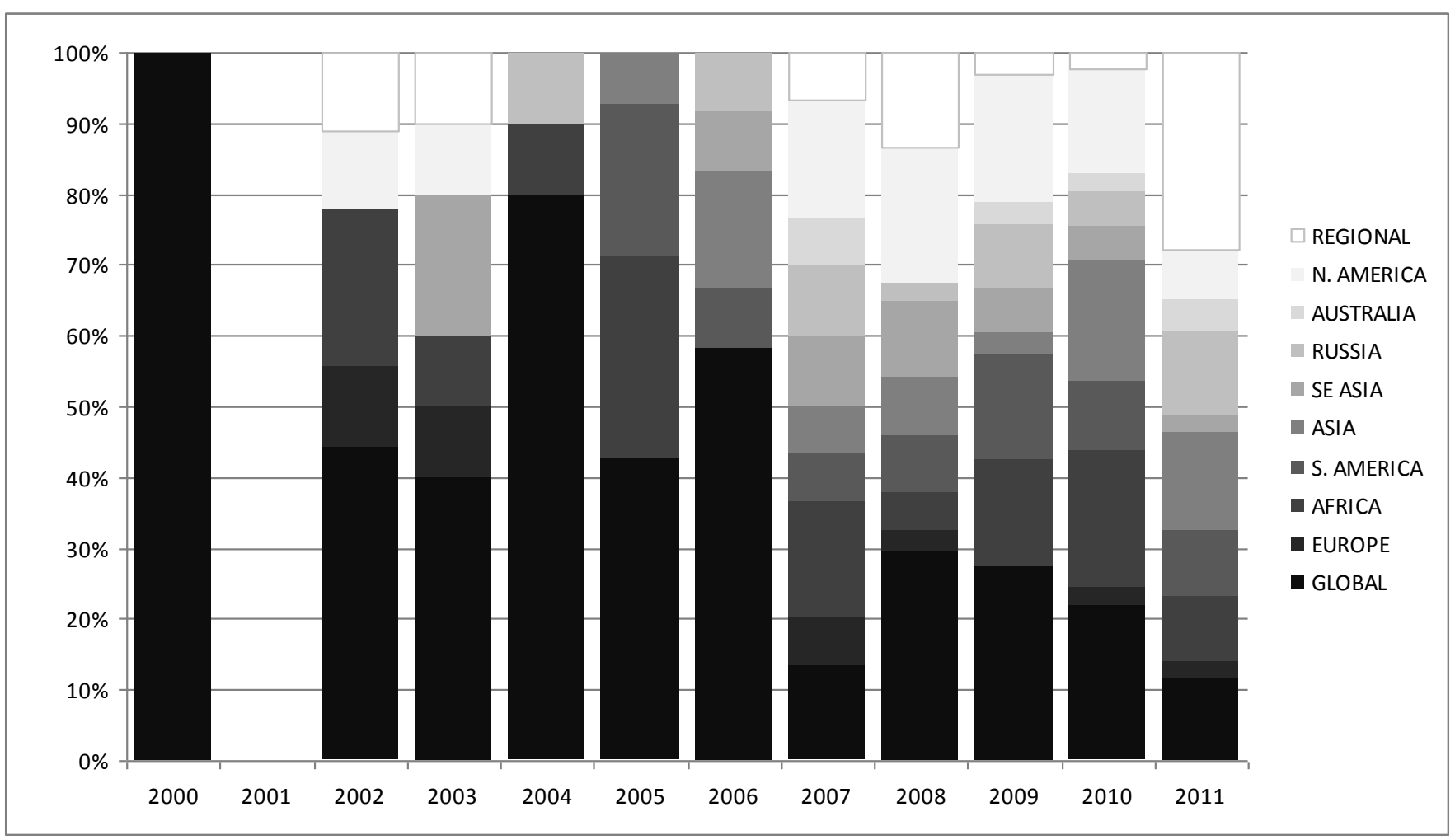


Figure 4

a)

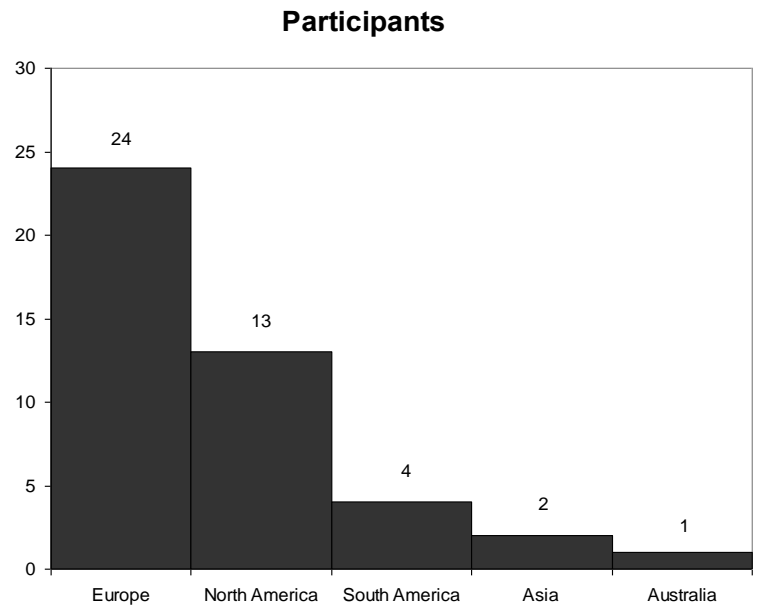

b)

Area of expertise

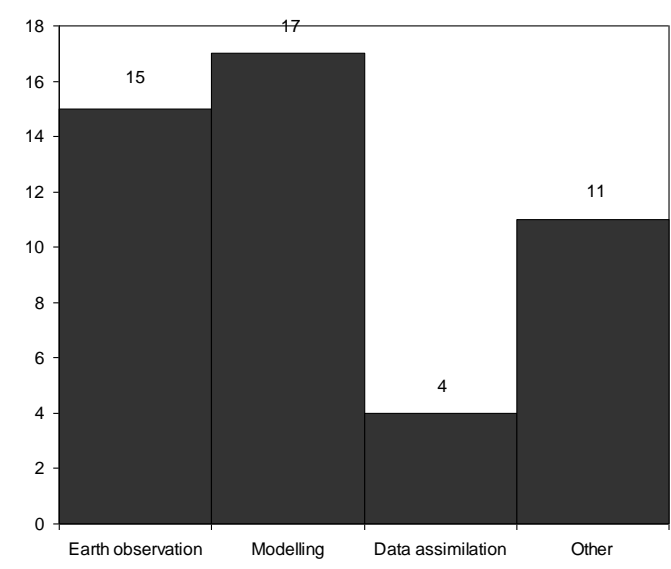


Figure 5

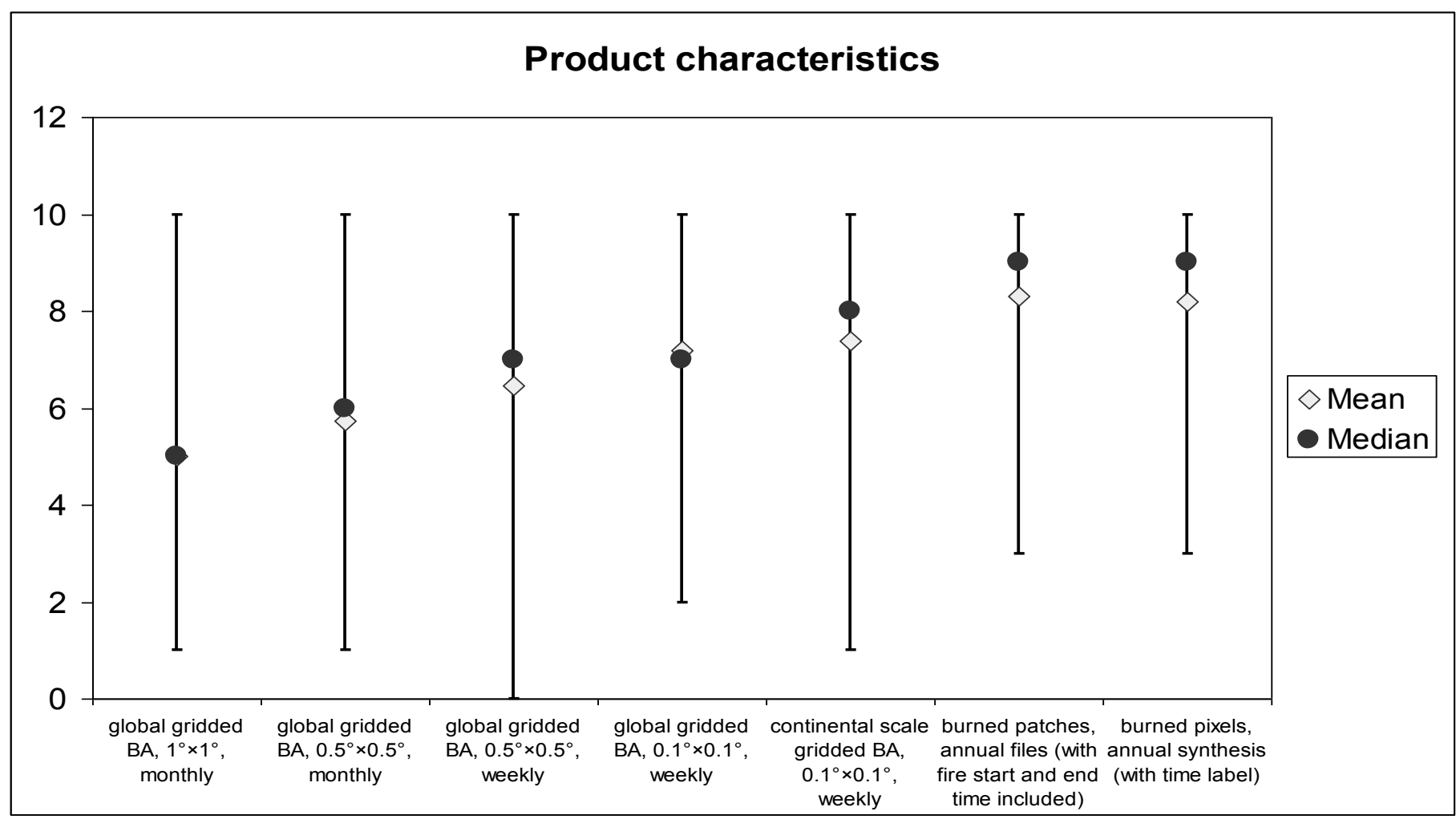


2 Table caption:

3 Table 1: Overview of global burned area dataset from spaceborne remote sensing

4 Table 2: Global fire models embedded in dynamic vegetation models and using global BA as 5 validation datasets.

6

7 Table 3: Satellite burned area algorithms developed for coarse resolution sensors.

8 Table 4: Synthesis table comparing BA estimates between BA products and compared to 9 ground datasets for major biomes.

10 Table 5: identified requirements for future BA products from previous user requirement 11 document delivered in international programmes/plans related to BA production or use.

13 Table 6: spatial and temporal accuracy requirements for future BA products based on 14 questionnaire to end-users

15 Table 7: Additional quality information expected for future BA products based on 16 questionnaire to end users (++: high interest, +ffair interest, 0: no opinion, -: no interest) 


\begin{tabular}{|c|c|c|c|c|c|c|c|}
\hline $\begin{array}{l}\text { Name of } \\
\text { Dataset }\end{array}$ & Time span & Satellite & $\begin{array}{l}\text { Spatial } \\
\text { resolution }\end{array}$ & $\begin{array}{l}\text { Temporal } \\
\text { resolution }\end{array}$ & Status & $\begin{array}{l}\text { Development } \\
\text { purpose }\end{array}$ & Source \\
\hline GFED3 & $\begin{array}{l}\text { 1996.07- } \\
\text { present }\end{array}$ & $\begin{array}{l}\text { MODIS } 500 \mathrm{~m} \text {, } \\
\text { TRIM/VIRS, } \\
\text { ATSR }\end{array}$ & $0.5 d \times 0.5 d$ & Monthly & Operational & $\begin{array}{l}\text { Atmospheric and } \\
\text { bio-geochemical } \\
\text { models }\end{array}$ & $\begin{array}{l}\text { Giglio et al. } \\
2010\end{array}$ \\
\hline$M C D 45 A 1$ & $2000-2009$ & MODIS $500 \mathrm{~m}$ & $500 \mathrm{~m}$ & Monthly & Operational & general purpose & $\begin{array}{l}\text { Roy et al. } \\
2008\end{array}$ \\
\hline L3JRC & $2000-2007$ & $\begin{array}{l}\text { SPOT } \\
\text { VEGETATION }\end{array}$ & $1 \mathrm{~km}$ & Daily & Finished & general purpose & $\begin{array}{l}\text { Tansey et } \\
\text { al. 2008 }\end{array}$ \\
\hline GLOBCARBON & $\begin{array}{l}1998.04- \\
2007.12\end{array}$ & $\begin{array}{l}\text { SPOT } \\
\text { VEGETATION, } \\
\text { ATSR-2, AATSR }\end{array}$ & $\begin{array}{l}1 \mathrm{~km}, 0.25 \text { or } \\
0.5 \text { degree }\end{array}$ & Monthly & Finished & $\begin{array}{l}\text { targeted for global } \\
\text { carbon cycling and } \\
\text { climate modelling } \\
\text { use }\end{array}$ & $\begin{array}{l}\text { Plummer et } \\
\text { al. } 2006\end{array}$ \\
\hline GBS & 1982-1999 & $\begin{array}{l}\text { NOAA-AVHRR } \\
\text { GAC } 8 \mathrm{~km} \text { data }\end{array}$ & $8 \mathrm{~km}$ & Weekly & Finished & $\begin{array}{l}\text { Globally consistent } \\
\text { records of global } \\
\text { fire activity. }\end{array}$ & $\begin{array}{l}\text { Carmona- } \\
\text { Moreno et } \\
\text { al. } 2005\end{array}$ \\
\hline GLOBSCAR & $>2000$ & ERS2-ATSR2 & $1 \mathrm{~km}$ & Monthly & Finished & $\begin{array}{l}\text { producing global } \\
\text { incremental } \\
\text { monthly maps of } \\
\text { burned areas }\end{array}$ & $\begin{array}{l}\text { Simon } \\
\text { al. } 2004\end{array}$ et \\
\hline GBA2000 & 2000 & $\begin{array}{l}\text { SPOT } \\
\text { VEGETATION }\end{array}$ & $1 \mathrm{~km}$ & Monthly & Finished & & $\begin{array}{l}\text { Tansey et } \\
\text { al. } 2004\end{array}$ \\
\hline
\end{tabular}

Table1 


\section{Table 3}

\begin{tabular}{|c|c|c|c|}
\hline Fire Module name & Fire processes & DGVM & reference \\
\hline TRIFFID & Constant & TRIFFID & Cox (2001) \\
\hline & $\begin{array}{l}\text { Fire occurrence Empirical } \\
\text { based on } \\
\text { Litter moisture } \\
\text { Litter amount } \\
\text { No BA no c emissions }\end{array}$ & $\begin{array}{l}\text { IBIS } \\
\text { ED } \\
\text { VeGAS-DGVM } \\
\text { SDGVM }\end{array}$ & $\begin{array}{l}\text { Kucharik (2000) } \\
\text { Moorcroft et al. (2001) } \\
\text { Zeng et al. (2010) } \\
\text { Woodward et al. (1995) } \\
\text { Woodward and lomas } \\
\text { (2004) } \\
\text { Bond et al. (2003) }\end{array}$ \\
\hline $\begin{array}{l}\text { CTEM fire (Arora and boer } \\
\text { 2005) }\end{array}$ & $\begin{array}{l}\text { Fire rate and spread, } \\
\text { prescribed consumption } \\
\text { and mortality } \\
\text { Wind speed and soil moist }\end{array}$ & CTEM & Arora (2003) \\
\hline $\begin{array}{l}\text { Glob FIRM (Thonicke et al. } \\
\text { 2001) }\end{array}$ & & $\begin{array}{l}\text { SEIB DGVM } \\
\text { CLM3.0 } \\
\text { ORCHIDEE } \\
\text { GOLM DGVM } \\
\text { CLM4, CNDV } \\
\text { LPJ }\end{array}$ & $\begin{array}{l}\text { Sato et al. (2007) } \\
\text { Levis et al. (2004) } \\
\text { Krinner et al. (2005) } \\
\text { Dai et al. (2003) } \\
\text { Oleson et al. (2010) } \\
\text { Sitch et al. (2003) }\end{array}$ \\
\hline $\begin{array}{l}\text { SPITFIRE (Thonicke et al. } \\
\text { 2010) }\end{array}$ & Lightening, human causes & $\begin{array}{l}\text { LPJ } \\
\text { LPJ guess } \\
\text { ORCHIDEE }\end{array}$ & $\begin{array}{l}\text { Sitch et al. (2003) } \\
\text { Smith et al. (2001) } \\
\text { Krinner et al. (2005) }\end{array}$ \\
\hline $\begin{array}{l}\text { MC fire (Lenihan and } \\
\text { Neilson 1998) }\end{array}$ & $\begin{array}{l}\text { Fire - vegetation } \\
\text { fire spread and } \\
\text { fire effect on mortality } \\
\text { based on drought index and } \\
\text { time since last fire }\end{array}$ & MC1 DGVM & Bachelet et al. (2001) \\
\hline Reg firm & $\begin{array}{l}\text { Regional } \\
\text { Climate fire danger } \\
\text { Ignition } \\
\text { spread }\end{array}$ & LPJ & Venevsky et al. 2002 \\
\hline
\end{tabular}


Table 2

\begin{tabular}{|c|c|c|c|c|}
\hline Reference & Method & Satellite sensor(s) & Domain & $\begin{array}{l}\text { Period } \\
\text { covered }\end{array}$ \\
\hline $\begin{array}{ll}\text { Kasischke } & \text { and } \\
\text { French, } 1995 & \end{array}$ & 15-day NDVI composite differences & AVHRR & Alaska & $1990-1991$ \\
\hline $\begin{array}{l}\text { Fernández et al., } \\
1997\end{array}$ & $\begin{array}{l}\text { 10-day NDVI maximum regression and } \\
\text { differencing }\end{array}$ & AVHRR & Spain & $1993-1994$ \\
\hline $\begin{array}{l}\text { Eva and Lambin, } \\
1998 \mathrm{a}\end{array}$ & $\begin{array}{l}\text { SWIR reflectance change and temperature } \\
\text { increase }\end{array}$ & ATSR & Africa & 1994-1995 \\
\hline Barbosa et al., 1999 & $\begin{array}{l}\text { daily } 5-\mathrm{km} \text { imagery analysis of reflectance, } \\
\text { brightness temperature and vegetation index } \\
\text { changes }\end{array}$ & AVHRR & Africa & $\begin{array}{l}1981-1983 \\
\text { and } \\
1985-1991\end{array}$ \\
\hline Roy et al., 1999 & $\begin{array}{l}\text { temporal composite of a spectral index (near } \\
\text { infrared minus reflective component of } \\
\text { middle infrared channel) for pixels with active } \\
\text { fire detection }\end{array}$ & AVHRR & southern Africa & $\begin{array}{l}1 \text { month in } \\
1989\end{array}$ \\
\hline Fraser et al., 2000 & $\begin{array}{l}\text { 10-day NDVI composite differencing } \\
\text { combined with active fire detection }\end{array}$ & AVHRR & Canada & $1995-1996$ \\
\hline Pereira et al., 2000 & $\begin{array}{l}\text { classification trees of (daily?) thermal, albedo } \\
\text { and vegetation index imagery }\end{array}$ & AVHRR & $\begin{array}{l}\text { central Africa and } \\
\text { lberia }\end{array}$ & \\
\hline Isaev et al., 2002 & NDVI differencing & $\begin{array}{l}\text { SPOT-HRSVIR and } \\
\text { RESURS-O/MSU-E }\end{array}$ & $\begin{array}{l}\text { Siberia (individual } \\
\text { fire) }\end{array}$ & 1997 \\
\hline Brivio et al., 2003 & Neural network classification scheme & $\begin{array}{l}\text { SPOT- } \\
\text { VEGETATION }\end{array}$ & $\begin{array}{l}\text { sub-Saharan } \\
\text { Africa }\end{array}$ & 2000 \\
\hline Fraser et al., 2004 & $\begin{array}{l}\text { logistic regression model on 10-day } \\
\text { composites of vegetation } \\
\text { subsequent region-growing }\end{array}$ & $\begin{array}{l}\text { SPOT- } \\
\text { VEGETATION }\end{array}$ & Canada & $1998-2000$ \\
\hline Gerard et al., 2003 & $\begin{array}{l}\text { NDSWIR differencing, classification of older } \\
\text { burn scars }\end{array}$ & $\begin{array}{l}\text { SPOT- } \\
\text { VEGETATION }\end{array}$ & Canada & 1998 \\
\hline $\begin{array}{l}\text { Stroppiana et al., } \\
2003\end{array}$ & $\begin{array}{l}\text { classification trees of } 10 \text {-day composite } \\
\text { thermal, albedo and vegetation index } \\
\text { imagery }\end{array}$ & $\begin{array}{l}\text { SPOT- } \\
\text { VEGETATION }\end{array}$ & northern Australia & 1999 \\
\hline Zhang et al., 2003 & $\begin{array}{l}\text { multi-temporal spectral } \\
\text { reflectance differencing criteria }\end{array}$ & $\begin{array}{l}\text { SPOT- } \\
\text { VEGETATION }\end{array}$ & $\begin{array}{l}\text { Russian } \\
\text { Federation }\end{array}$ & 2001 \\
\hline Pu et al., 2004 & similar to Fraser et al., 2000 & AVHRR & $\begin{array}{l}\text { western } \\
\text { America }\end{array}$ & \\
\hline Simon et al., 2004 & $\begin{array}{l}\text { two algorithms: (1) contextual NIR } \\
\text { reflectance and (TIR) brightness temperature } \\
\text { change, (2) series of fixed thresholds }\end{array}$ & ATSR-2 and AATSR & global & 2000 \\
\hline Sukhinin et al., 2004 & $\begin{array}{l}\text { similar to Fraser et al., } 2000 \text {, but burn scar } \\
\text { mapping based on post fire scenes only }\end{array}$ & AVHRR & Siberia & $1995-2003$ \\
\hline Tansey et al., 2004 & $\begin{array}{l}\text { nine different regional algorithms analysing } \\
\text { surface reflectance changes }\end{array}$ & $\begin{array}{l}\text { SPOT- } \\
\text { VEGETATION }\end{array}$ & global & 2000 \\
\hline $\begin{array}{l}\text { Carmona-Moreno et } \\
\text { al., } 2005\end{array}$ & variant of Barbosa et al., 1999 algorithm & AVHRR & global & 1982-1999 \\
\hline Roy et al., 2005b & $\begin{array}{l}\text { deviations from bi-directional reflectance } \\
\text { model expected reflectance }\end{array}$ & MODIS & $\begin{array}{l}\text { test regions on } \\
\text { several continents }\end{array}$ & 2002 \\
\hline George et al., 2006 & $\begin{array}{l}\text { normalized shortwave IR difference and } \\
\text { NDVI differences, active fire detection for } \\
\text { dating }\end{array}$ & MODIS & central Russia & $1992-2003$ \\
\hline Giglio et al., 2006 & $\begin{array}{l}\text { regional regression trees of active fire } \\
\text { detections correlated with persistent changes } \\
\text { in vegetation index and NIR reflectance } \\
\text { (extension of Roy et al., 1999) }\end{array}$ & MODIS & global & $2000-2005$ \\
\hline Loboda et al., 2007 & $\begin{array}{l}\text { 8-day surface reflectance composite } \\
\text { changes (normalized burned ratio } \\
\text { differencing) and active fire masks }\end{array}$ & MODIS & $\begin{array}{l}\text { test regions in } \\
\text { North America } \\
\text { and Siberia }\end{array}$ & $2001-2005$ \\
\hline Pu et al., 2007 & $\begin{array}{l}\text { similar to Fraser et al., 2003, combined with } \\
\text { active fire detection }\end{array}$ & AVHRR & North America & $1989-2000$ \\
\hline Tansey et al., 2008 & "one of GBA-2000" algorithms & $\begin{array}{l}\text { SPOT- } \\
\text { VEGETATION }\end{array}$ & global & $2000-2007$ \\
\hline $\begin{array}{l}\text { Giglio et al., } 2009, \\
\text { Giglio et al., } 2010\end{array}$ & similar to Giglio et al., 2006 & MODIS & global & $2001-2009$ \\
\hline
\end{tabular}


Table 4

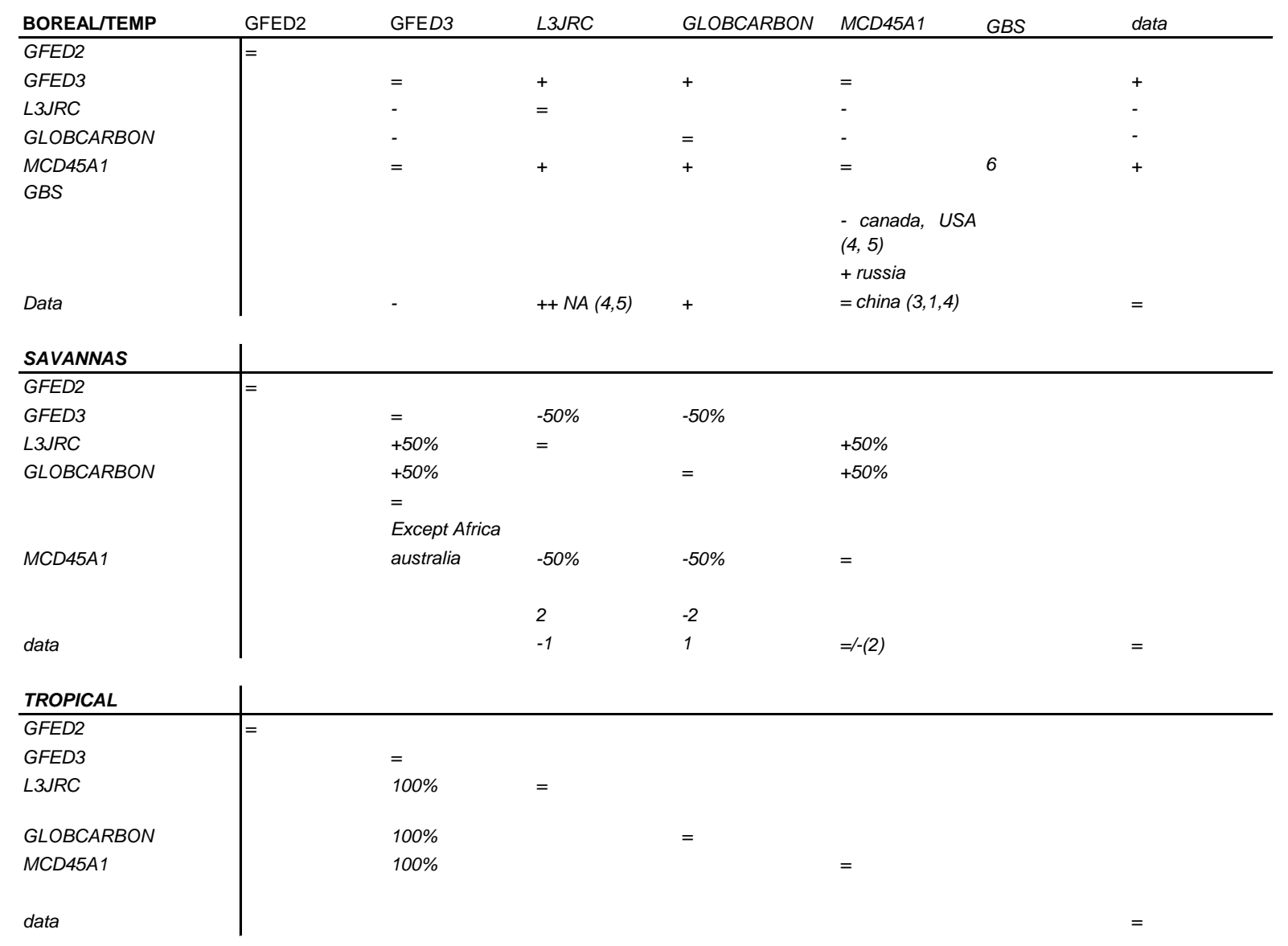

(1) Giglio et al. (2010)

(2) Roy and boschetti (2009)

(3) Chang and song (2009)

(4) Kasischke et al. (2011)

(5) Loboda et al. (2011)

(6) Camona-moreno etal (2005) 
Table 5

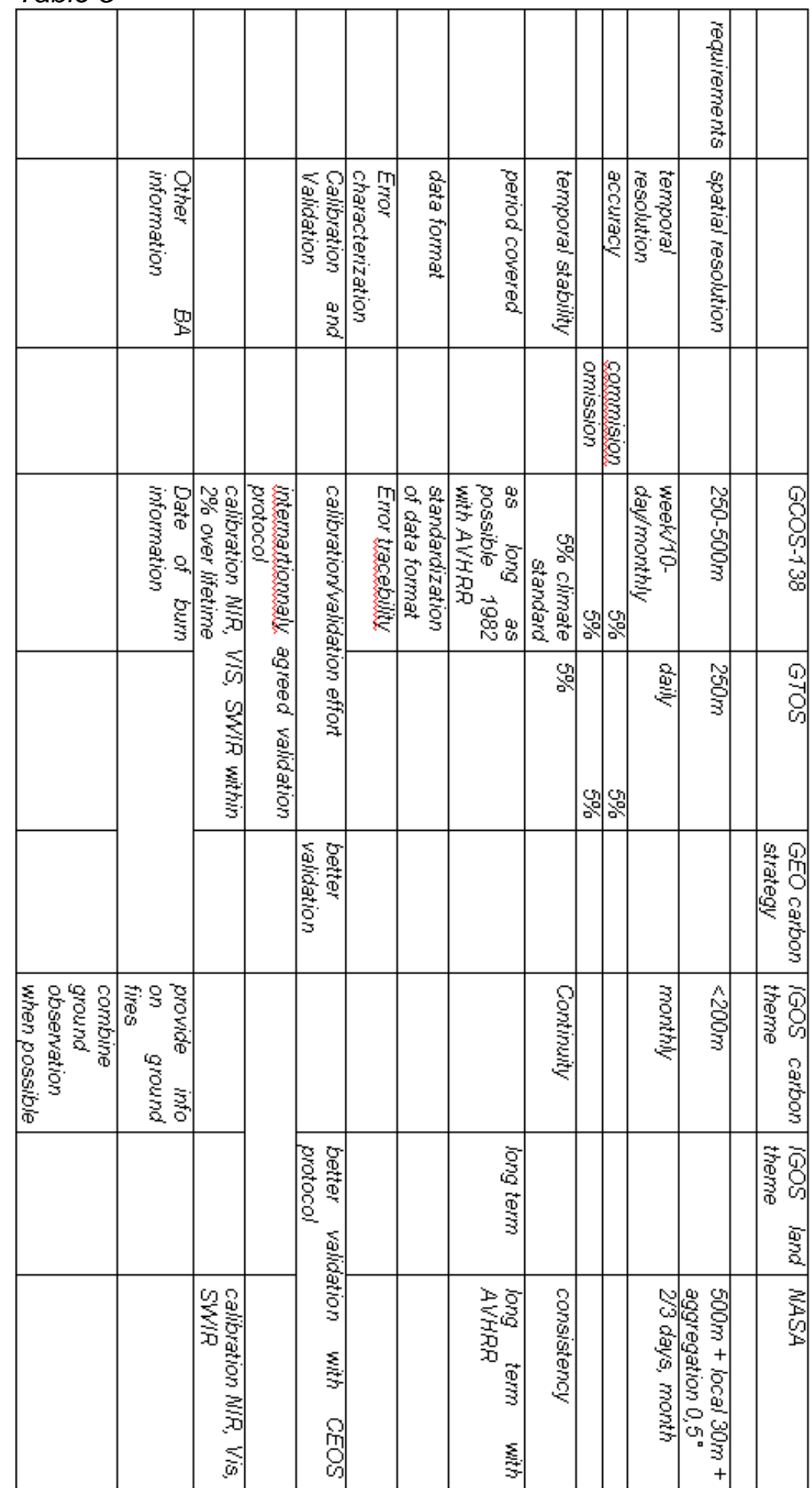


Table 6

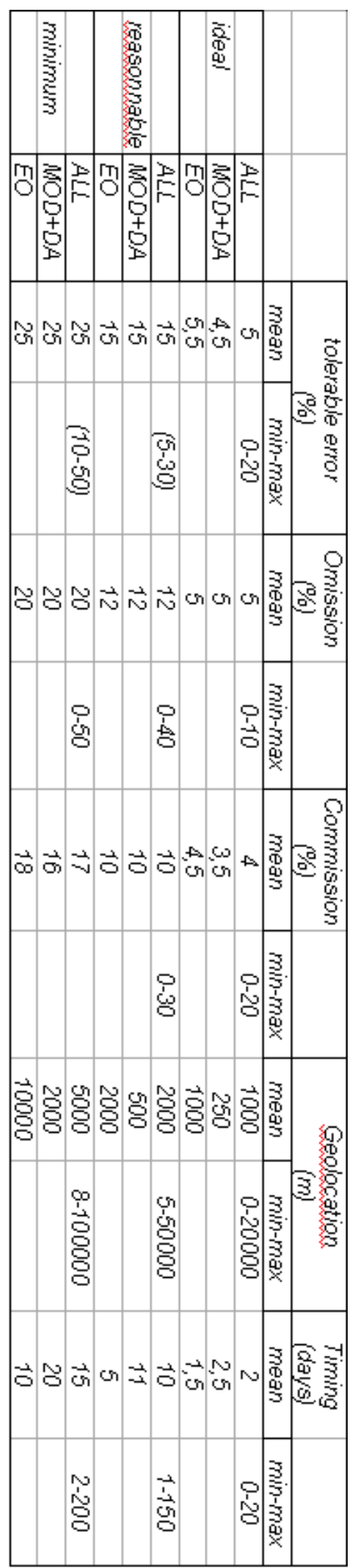


Table 7

\begin{tabular}{|c|c|c|c|c|c|c|}
\hline & $\begin{array}{c}\text { pixel } \\
\text { based }\end{array}$ & & patch & \multicolumn{3}{|c|}{ grid } \\
\hline & MOD DA & $E O$ & $M O D D A$ & $E O$ & $M O D D A$ & $E O$ \\
\hline burn severity & ++ & + & & & ++ & + \\
\hline date of burn detection & ++ & ++ & '++ & ++ & & \\
\hline cloud contamination & 0 & + & & & & \\
\hline cloud shadow contamination & 0 & + & & & & \\
\hline topographic shadow & - & + & & & & \\
\hline smoke & 0 & + & & & & \\
\hline snow & - & 0 & & & & \\
\hline water & - & 0 & & & & \\
\hline dominant vegetation cover & ++ & + & ++ & + & ++ & + \\
\hline confidence level & + & ++ & & & & \\
\hline geolocation & & & ++ & + & & \\
\hline burnd area & & & ++ & ++ & & \\
\hline sensor & & & 0 & + & & \\
\hline Algorithm & & & 0 & + & & \\
\hline temporal variability & & & & & + & + \\
\hline omission & & & & & + & ++ \\
\hline commission & & & & & + & ++ \\
\hline
\end{tabular}


Annex 1 : questionnaire sent to end-users

\section{1) User identification}

If you prefer to stay anonymous you can do so, but please provide your institution and area of expertise in any case so that we can better link your requirements with specific user communities. If you think you belong to more than one user community with different requirements, please fill in two forms (don't mix use cases).

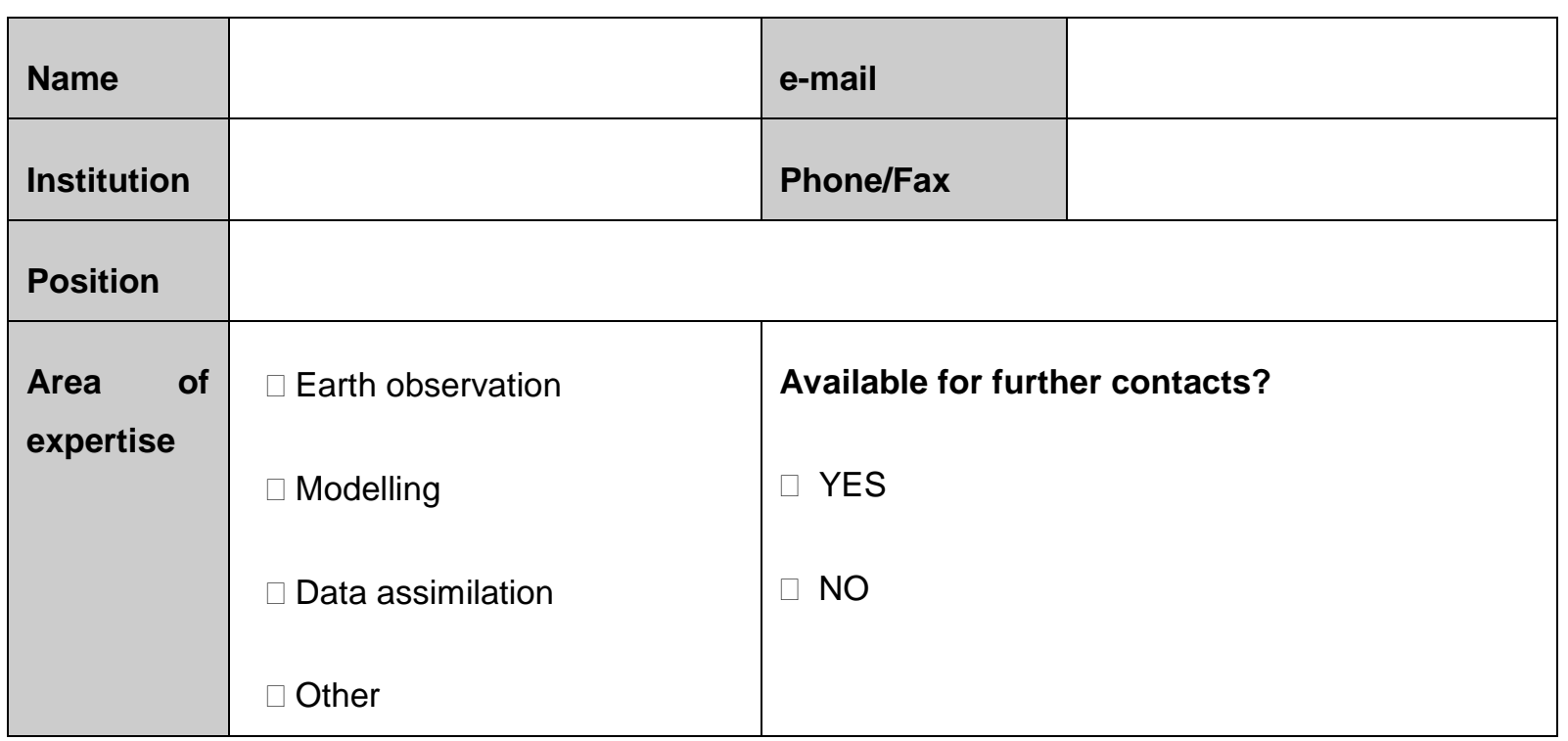

If you work on Earth observations, please indicate type of measurement, platform, interest in fire data:

If you work with models or data assimilation, please indicate type of model, domain (global/regional/...), typical resolution, interest in fire data. Also in this box please tell us how you are using fire data. Please insert links to relevant web pages if appropriate:

If you think you belong to a different user community, please specify: 


\section{2) Product Use}

Mark with an ' $\mathbf{X}$ ' if the BA product is needed for the application and/or comment.

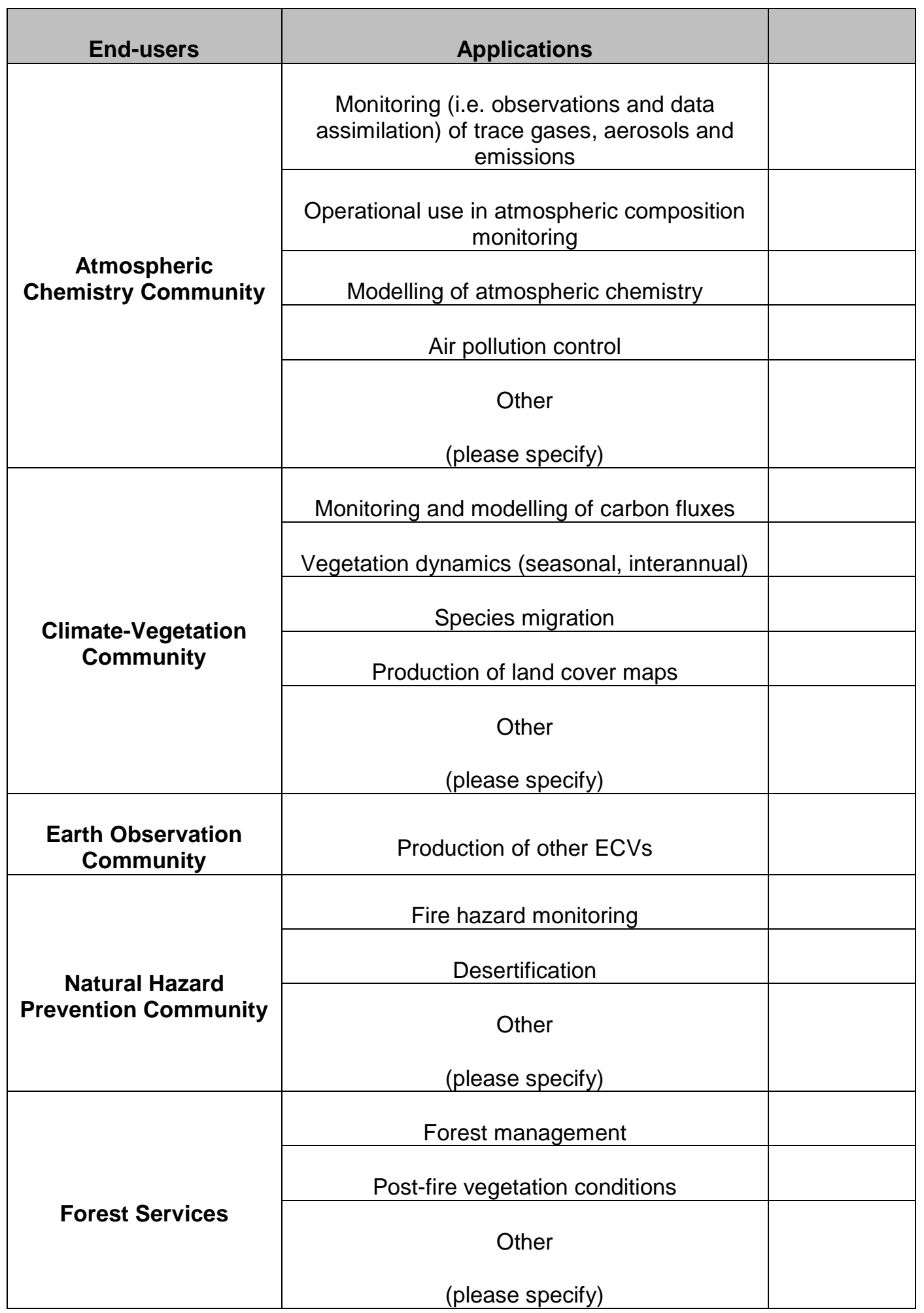


If you have used any other burned area products in your activities, please give some references and list what were the main advantages and limitations of each one:

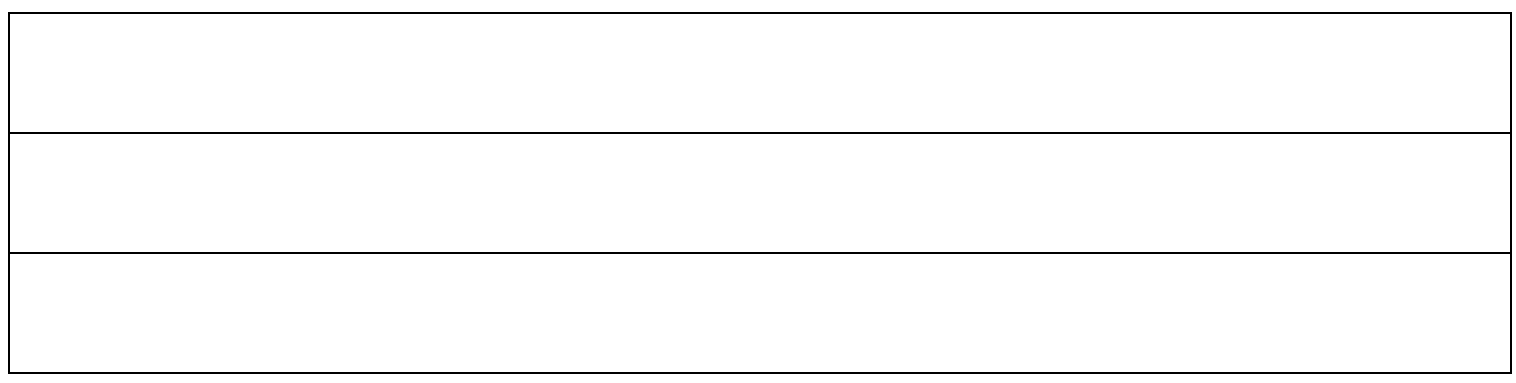

\section{3) Product characteristics}

In order to take into account the heritage of existing satellite fire products, we are proposing a few examples for the type of product that could be generated. Please indicate on a scale from 1 (very low) to 10 (extremely useful) the value that each of these products would have for your work. If you don't see any relevance of a specific product you can either leave the line blank or enter 0 . Please try to establish a ranking so that not more than two product types are marked with the same grade.

Please note: data format and metadata requests will be addressed below.

\begin{tabular}{|c|c|}
\hline Product type & Relevance (0..10) \\
\hline global gridded $\mathrm{BA}, 1^{\circ} \times 1^{\circ}$, monthly, lat-lon coordinates & \\
\hline global gridded $\mathrm{BA}, 0.5^{\circ} \times 0.5^{\circ}$, monthly, lat-lon coordinates & \\
\hline global gridded BA, $0.5^{\circ} \times 0.5^{\circ}$, weekly, lat-lon coordinates & \\
\hline global gridded BA, $0.1^{\circ} \times 0.1^{\circ}$, weekly, lat-lon coordinates & \\
\hline $\begin{array}{l}\text { continental scale } \quad \text { gridded } \quad \mathrm{BA}, \quad 0.1^{\circ} \times 0.1^{\circ}, \quad \text { weekly } \\
\text { continent/region: } \\
\text { coordinate system: }\end{array}$ & \\
\hline burned patches, annual files (with fire start and end time included) & \\
\hline burned pixels, annual synthesis (with time label) & \\
\hline $\begin{array}{l}\text { Own characteristics (please use categories similar to the above to } \\
\text { describe your product requirements) }\end{array}$ & \\
\hline
\end{tabular}


4) Product Accuracy and Quality Control

Please try to estimate your accuracy requirements in the three categories "ideal" (wish I had this), "reasonable" (would be good if they can do this) and "minimum" (if it is any worse then this it becomes useless):

\begin{tabular}{|l|l|l|l|}
\hline \multicolumn{1}{|c|}{ Product Accuracy } & Ideal & Reasonable & Minimum \\
\hline Burned area (in \%) & & & \\
\hline $\begin{array}{l}\text { Completeness (omission } \\
\text { errors in \%) }\end{array}$ & & & \\
\hline $\begin{array}{l}\text { False } \\
\text { (commission errors in \%) }\end{array}$ & & & \\
\hline Geolocation Accuracy (in m) & & & \\
\hline Temporal accuracy (in days) & & & \\
\hline $\begin{array}{l}\text { Temporal stability (in \% per } \\
\text { annum) }\end{array}$ & & & \\
\hline Other (please specify) & & & \\
\hline
\end{tabular}

temporal accuracy means correctness of time label. Some burn scars can be shielded by clouds for a while before they are detected, or satellite overpasses don't allow for an earlier detection. If your requirements are not stringent in this area, this may also ease processing requirements.

Have you used accuracy information of fire products previously? If so, please describe your experiences and the sensitivity of your model/application to product errors (e.g. reference to a publication). If you have not yet used accuracy information of fire products, please state why not.

\section{5) Metadata and Quality Flags}


Please indicate the metadata information you wish to see attached to the data. If you request a different kind of information please enter a note below the table.

\begin{tabular}{|c|c|c|c|c|}
\hline $\begin{array}{l}\text { Type of } \\
\text { Product }\end{array}$ & Options & Important & $\begin{array}{l}\text { Nice to } \\
\text { have }\end{array}$ & $\begin{array}{c}\text { Unimporta } \\
\text { nt }\end{array}$ \\
\hline \multirow{11}{*}{ Pixel-based } & $\begin{array}{l}\text { Burn severity (low, moderate, high, } \\
\text { very high) }\end{array}$ & & & \\
\hline & Date of burn detection & & & \\
\hline & Cloud contamination & & & \\
\hline & Cloud shadow contamination & & & \\
\hline & Topographic shadow contamination & & & \\
\hline & Smoke contamination & & & \\
\hline & Snow contamination & & & \\
\hline & Water contamination & & & \\
\hline & Dominant vegetation cover & & & \\
\hline & Confidence level & & & \\
\hline & Other (please specify) & & & \\
\hline \multirow{9}{*}{$\begin{array}{l}\text { Burned } \\
\text { patches }\end{array}$} & Geolocation of centre & & & \\
\hline & Burned area & & & \\
\hline & Start date of burn & & & \\
\hline & End date of burn & & & \\
\hline & Dominant vegetation cover & & & \\
\hline & Dominant vegetation cover fraction & & & \\
\hline & Sensor & & & \\
\hline & Algorithm Code & & & \\
\hline & Other (please specify) & & & \\
\hline \multirow{7}{*}{$\begin{array}{l}\text { Gridded } \\
\text { data }\end{array}$} & Dominant vegetation cover & & & \\
\hline & Dominant vegetation cover fraction & & & \\
\hline & Temporal variability index & & & \\
\hline & $\begin{array}{c}\text { Burn severity classes }(1,2,3)(\% \text { of } \\
\text { each class) }\end{array}$ & & & \\
\hline & Omission error estimate & & & \\
\hline & Commission error estimate & & & \\
\hline & Other (please specify) & & & \\
\hline
\end{tabular}

Notes:

6) Data Format and Product Dissemination 


\begin{tabular}{|c|c|c|c|}
\hline File format & Ideal & Reasonable & Minimum \\
\hline ASCII Files & & & \\
\hline GEOTIFF & & & \\
\hline ArcGIS shape & & & \\
\hline HDF5 & & & \\
\hline netcdf & & \\
\hline $\begin{array}{c}\text { Other } \\
\text { (please specify) }\end{array}$ & & \\
\hline Metadata format: & & & \\
\hline $\begin{array}{c}\text { Standard ISO 19115 with } \\
\text { extension to raster format }\end{array}$ & & & \\
\hline METAFOR & & & \\
\hline CF & & & \\
\hline
\end{tabular}

\begin{tabular}{|c|c|c|c|}
\hline Mechanisms & Ideal & Reasonable & Minimum \\
\hline $\begin{array}{c}\text { Internet web mapping } \\
\text { service }\end{array}$ & & & \\
\hline Web download & & & \\
\hline Web coverage service & & & \\
\hline FTP & & & \\
\hline On-demand & & & \\
\hline Other (please specify) & & & \\
\hline
\end{tabular}

Are you accustomed to downloading data from one of the following portals?

\section{ESA facilities}


$\square$ Global Master Directory

\section{7) Other issues}

Here is room for any other comments or suggestions you might have:

\section{8) Outlook}

Provided that the final burned area product meets the above proposed specifications, how would you estimate the potential benefits for improvements in your field of application/research?

Would you be interested to get involved in the testing of the new burned area product?

\section{$\square$ YES}

NO

Would you be interested in a user workshop on the new product should such a meeting be organized?

\section{YES}

NO

If you could influence the design of new satellite instruments and define the fire product characteristics, what kind of fire data products would you like to see (please use the categories above to describe your optimum product): 


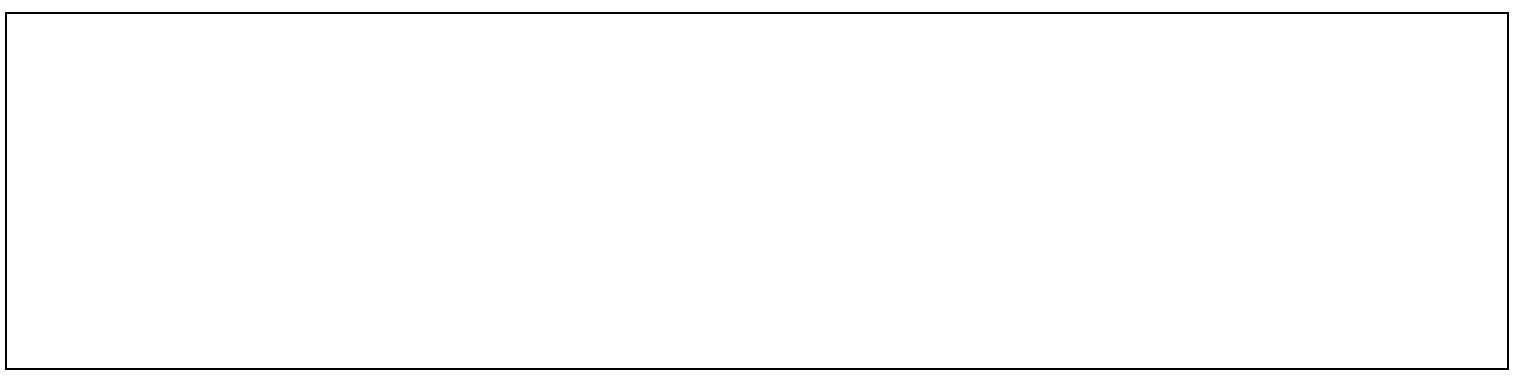


1 Annex 2: list of references using spaceborne remote sensing BA products or active 2 fires, and their corresponding fields for BA or active fire product's name, scale of 3 application, biome studied and field of research.

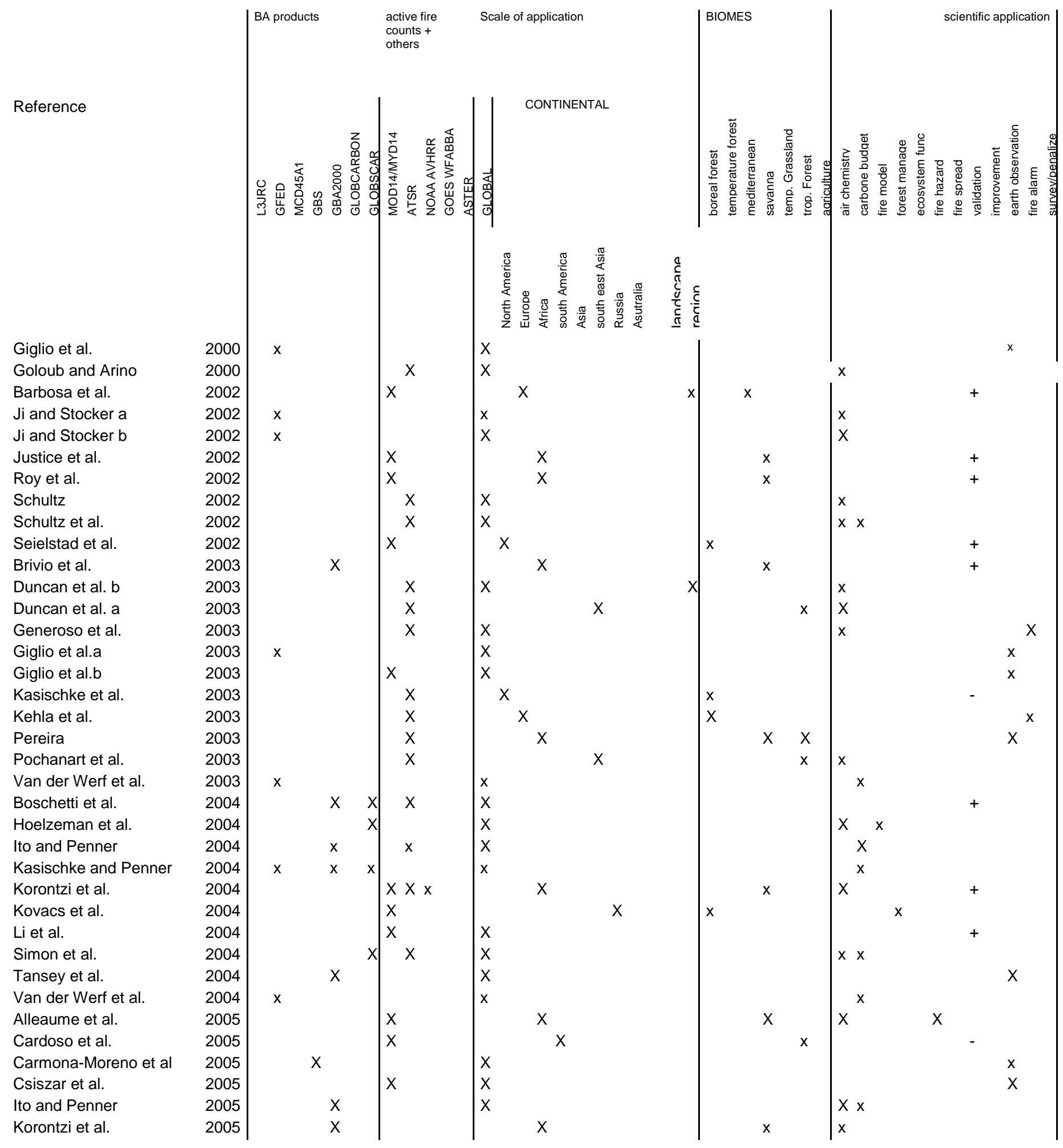




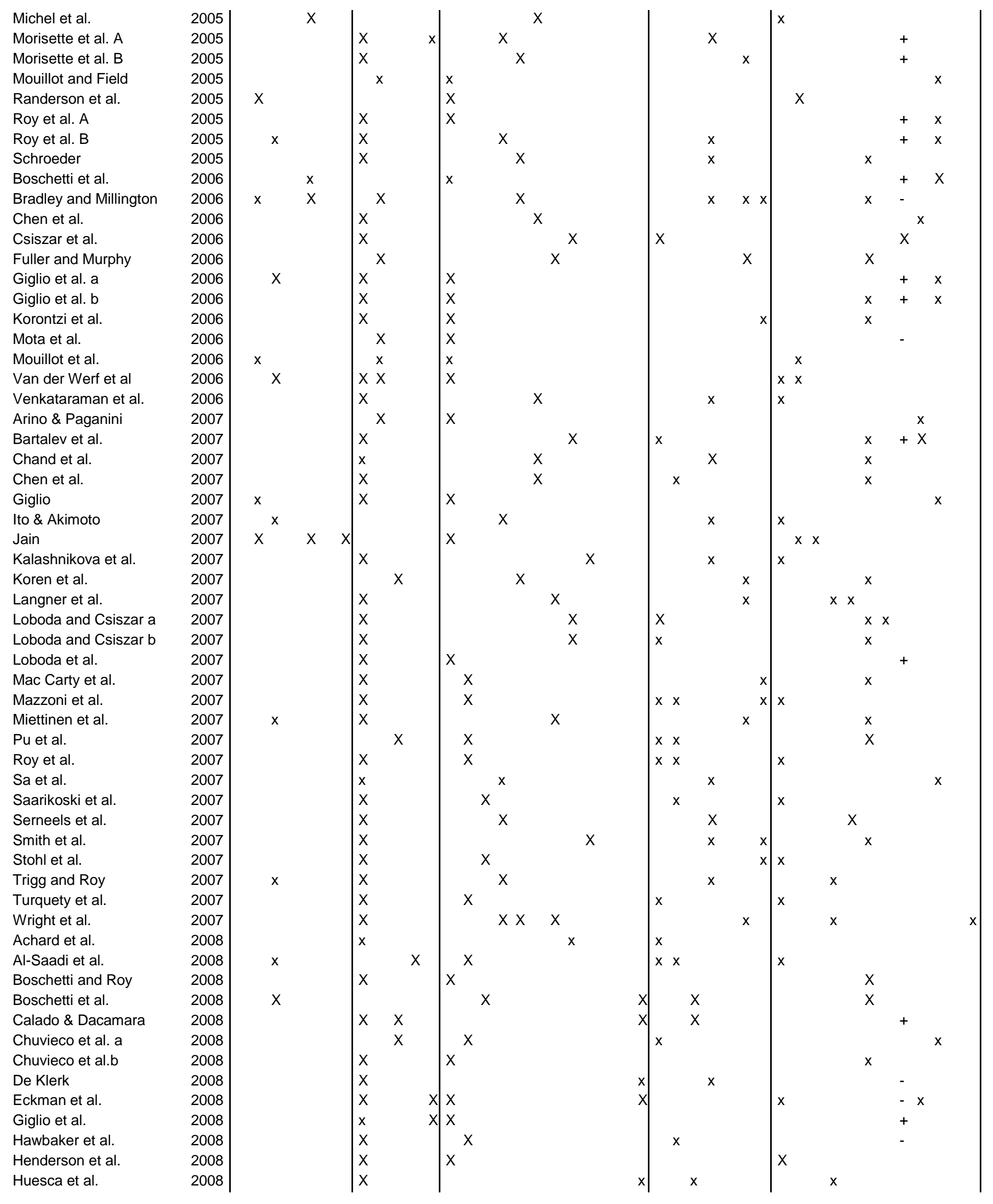




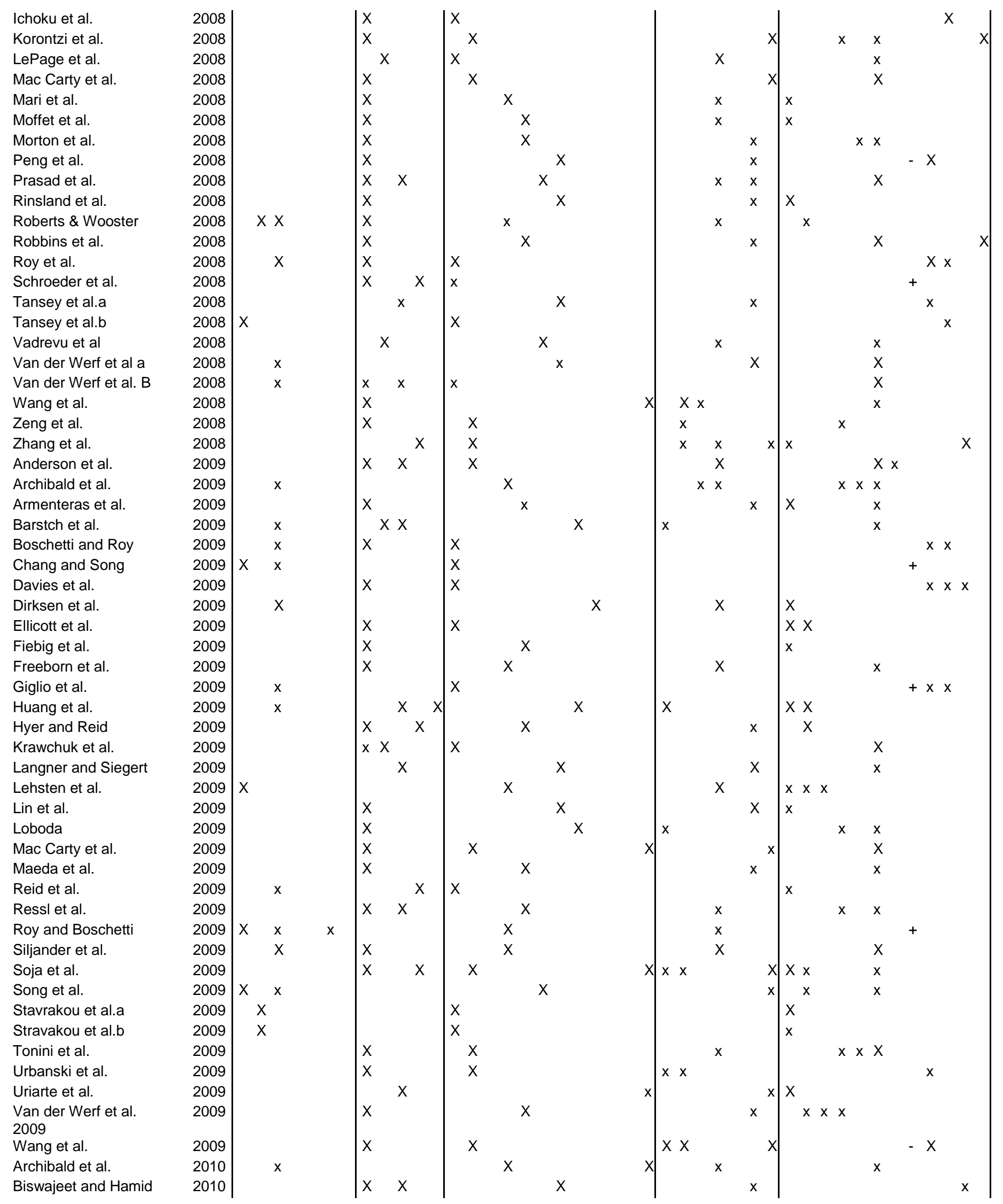




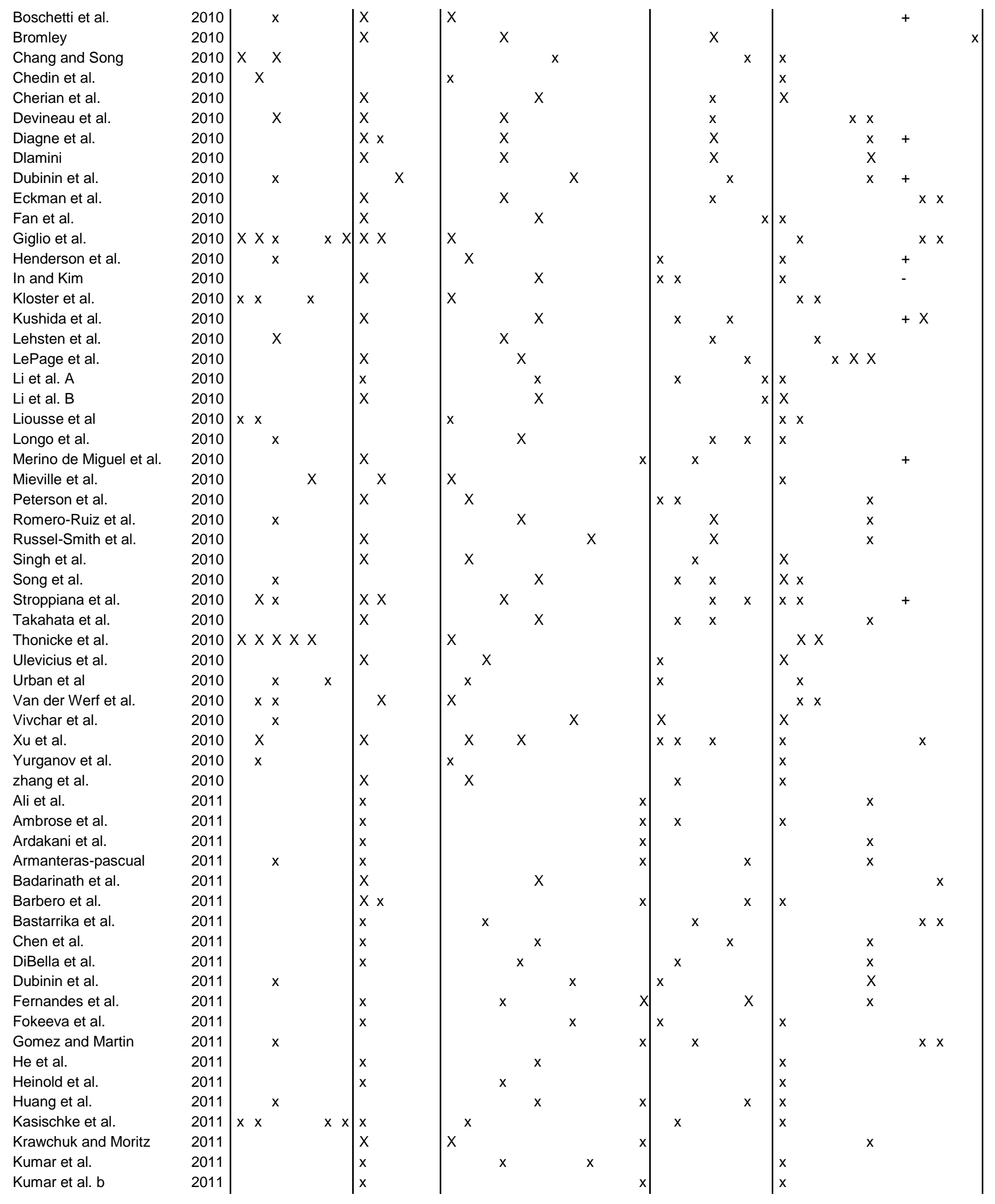




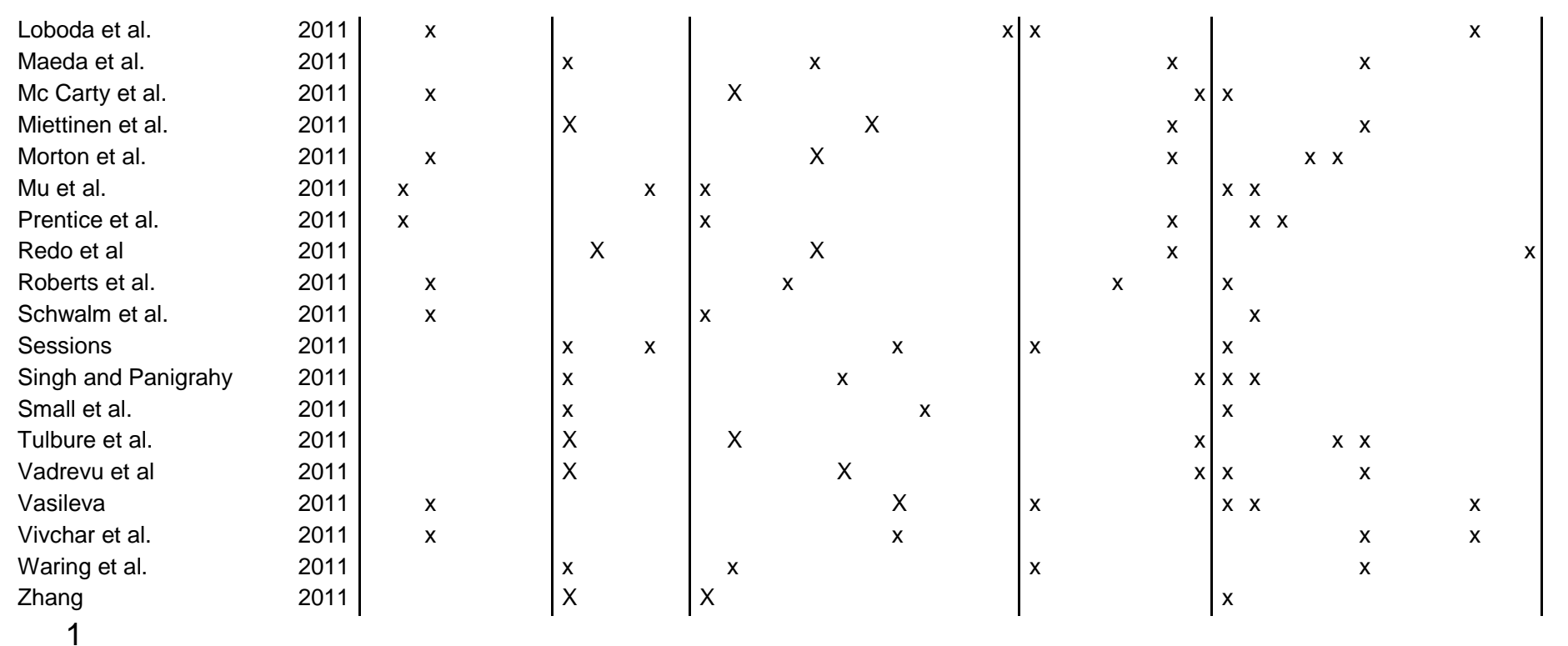

2

Annex References

Achard F., Eva H.D., Mollicone D. Beuchle R. 2008. The effect of climate anomalies and 6 human ignition factor on wildfires in Russian boreal forests. Philosophical 7 Transactions of the Royal Society B -Biological Sciences 363(1501), 2331-2339.

8 Ali S.A., Mohammad J.V.Z. Ali M., Ali M., 2011. The north of Iran fire regimes 9 assessment with MODIS fire data : their relationship to PNPI and temperature 10 (2001-2008). Disaster Advances 4(3), 43-50.

11 Alleaume, S., Hely, C., Le Roux, J., Korontzi, S., Swap, R.J., Shugart, H.H., Justice, C.O. 12 2005. Using MODIS to evaluate heterogeneity of biomass burning in southern

13 African savannahs: a case study in Etosha. International Journal of Remote $14 \quad$ Sensing 26(19), 4219-4237.

15 Al-Saadi, J., Soja, A., Pierce, R.B., Szykman, J., Wiedinmyer, C., Emmons, L., 16 Kondragunta, S., Zhang, X.Y., Kittaka, C., Schaack, T., Bowman, K. 2008. 17 Intercomparison of near-real-time biomass burning emissions estimates constrained 18 by satellite fire data. Journal of Applied Remote Sensing 2, 21504.

19 Ambrose J.L., Reidmiller D.R., Jaffe D.A. 2011. Causes of high O3 in the lower free 20 troposphere over the Pacific Northwest as observed at the Mt Bachelor Observatory. $21 \quad$ Atmospheric Environment 45, 5302-5315.

22 Anderson, K.R., Englefield, P., Little, J.M., Reuter, G. 2009. An approach to operational 23 forest fire growth predictions for Canada. International Journal of Wildland Fire18(8), 24 893-905.

25 Archibald, S., Roy, D.P., van Wilgen, B.W., Scholes, R.J. 2009. What limits fire? An 26 examination of drivers of burnt area in Southern Africa. Global Change Biology 15 $27 \quad$ (3), 613-630.

28 Archibald, S., Scholes, R.J., Roy, D.P., Roberts, G., Boschetti, L. 2010. Southern African 29 fire regimes as revealed by remote sensing. International Journal of Wildland Fire $3019(7), 861-878$.

31 Ardakani, A.S., Zoej, M.J.V., Mohammadzadeh, A., Mansourian, A. 2011. Spatial and 32 Temporal Analysis of Fires Detected by MODIS Data in Northern Iran From 2001 to 33 2008.IEEE Journal of Selected Topics in Applied Earth Observation and Remote 34 sensing $4(1), 216-225$. 
1 Arino, O., Paganini, M. 2007. ESA activities related to forest fires: ATSR World Fire Atlas

4 Armenteras, D., Gonzalez-Alonso, F., Acuilera, C.F. 2009. Geographic and temporal (WFA) GlobCarbon RISK-EOS - art. no. 674206. Remote Sensing for Agriculture distribution of fire in Colombia using thermal anomalies data. Caldasia 31(2), 303318.

Armenteras-Pascual, D., Retana-Alumbreros, J., Molowny-Horas, R., Roman-Cuesta, R.M., Gonzalez-Alonso, F., Morales-Rivas, M. 2011. Characterising fire spatial pattern interactions with climate and vegetation in Colombia. Agricultural and Foresy Meteorology 151 (3), 279-289.

Badarinath, K.V.S., Sharma, A.R., Kharol, S.K. 2011. Forest fire monitoring and burnt area mapping using satellite data: a study over the forest region of Kerala State India. International Journal of Remote Sensing 32(1), 85-102.

Barbero R., Moron V., Mangeas M. Despinoy M., Hely C. 2011. Relationships between MODIS and ATSR fires and atmopsheric variability in New Caledonia (SW pacific). Journal of Geophysical Research-Atmosphere 116, D21110.

Barbosa, P.A., San-Miguel-Ayanz, J., Schmuck, G. 2002. Remote sensing of forest fires in Southern Europe using IRS-WiFS and MODIS data. Remote Sensing for Environmental Monitoring GIS Application and Geology 4545, 165-173.

Bartalev, S.A., Egorov, V.A., Loupian, E.A., Uvarov, I.A. 2007. Multi-year circumpolar assessment of the area burnt in boreal ecosystems using SPOT-VEGETATION. International Journal of Remote Sensing 28(6), 1397-1404.

Bartsch, A., Balzter, H., George, C. 2009. The influence of regional surface soil moisture anomalies on forest fires in Siberia observed from satellites. Environmental Research Letters 4(4), 45021.

Bastarrika A., Chuvieco E., Martin P.M. 2011. Automated burned land mapping from MODIS time series images: assessment in Mediterranean Ecosystems. IEEE Transactions on Geosciences and Remote Sensing 49(9), 3401-3413.

Biswajeet, P., Hamid, A. 2010. Forest Fire Detection and Monitoring using High Temporal MODIS and NOAA AVHRR Satellite Images in Peninsular Malaysia. Disaster Advances 3(2), 18-23.

Boschetti, L., Brivio, P.A., Eva H.D., Gallego, J., Baraldi, A., Gregoire, J.M. 2006. A sampling method for the retrospective validation of Global Burned Area products. IEEE Transactions on Geosciences and Remote Sensing 44(7), 1765-1773.

Boschetti, L., Eva, H.D., Brivio, P.A., Gregoire, J.M. 2004. Lessons to be learned from the comparison of three satellite-derived biomass burning products. Geophysical Research Letters 31(21), L21501.

Boschetti, L., Roy D., Barbosa, P., Boca R., Justice, C. 2008. A MODIS assessment of the summer 2007 extent burned in Greece. International Journal of Remote Sensing 29(8), 2433-2436.

Boschetti, L., Roy, D.P. 2009. Strategies for the fusion of satellite fire radiative power with burned area data for fire radiative energy derivation. Jounral of Geophysical Research - Atmosphere 114, D20302.

Boschetti, L., Roy, D.P. 2008. Defining a fire year for reporting and analysis of global interannual fire variability. Journal of Geophysical Research - Biogeosciences 113(G3), G03020.

Boschetti, L., Roy, D.P., Justice, C.O., Giglio L. 2010. Global assessment of the temporal reporting accuracy and precision of the MODIS burned area product. International Journal of Wildland Fire 19(6), 705-709. 
1 Bradley, A.V., Millington, A.C. 2006. Spatial and temporal scale issues in determining 2 biomass burning regimes in Bolivia and Peru. International Journal of Remote $3 \quad$ Sensing 27(11), 2221-2253.

4 Brivio, P.A., Maggi, M., Binaghi, E., Gallo, I. 2003. Mapping burned surfaces in subof Remote Sensing 24(20), 4003-4018.

Bromley, L. 2010. Relating violence to MODIS fire detections in Darfur Sudan. International Journal of Remote Sensing 31(9), 2277-2292.

Calado, T.J., DaCamara, C.C. 2008. Dating fire events on end of season maps of burnt scars. GEOENV VI - Geostatistics for environmental application proceedings15, 323-333.

Cardoso, M.F., Hurtt, G.C., Moore, B., Nobre, C.A., Bain, H. 2005. Field work and statistical analyses for enhanced interpretation of satellite fire data. Remote Sensing of Environment 96(2), 212-227.

Carmona-Moreno, C., Belward, A., Malingreau, J.-P., Hartley, A., Garcia-Alegre, M., Antonovskiy, M., Buchshtaber, V., and Pivovarov, V. 2005. Characterizing interannual variations in global fire calendar using data from Earth observing satellites. Global Change Biology 11, 1537-1555.

Chand T.R.K., Badarinath, K.V.S., Murthy, M.S.R., Rajshekhar, G., Elvidge, C.D., Tuttle, B.T. 2007. Active forest fire monitoring in taranchal state India using multi-temporal DMSP-OLS and MODIS data. International Journal of Remote Sensing 28(10), 2123-2132.

Chang, D., Song, Y. 2009. Comparison of L3JRC and MODIS global burned area products from 2000 to 2007. Journal of Geophysical Research - Atmosphere 114, D16106.

Chang, D., Song, Y.2010. Estimates of biomass burning emissions in tropical Asia based on satellite-derived data. Atmospheric Chemistry and Physics10(5), 2335-2351.

Chedin A., Scott NA, Armante R., Pierangelo C., Crevoisier C., Fosse O., ciais P. A quantitative link between $\mathrm{CO}(2)$ emissions from tropical vegetation fires and the daily tropospheric excess (DTE) of CO(2) seen by NOAA-10 (1987-1991). Journal of Geophysical Research - Atmosphere 113(D5), D05302.

Chen, S.H., Zeng, Z.Y., Liu, J.P., Zhang, S.Z., Zhang, X.Q., Li FT. 2006. A multilayer contextual fire detection model for MODIS. Geophysical Solutions for Environmental Engineering 1-2, 1129-1132.

Chen, Y.H., Li, J., Peng, G.X. 2007. Forest fire risk assessment combining remote sensing and meteorological information. New Zealand Journal of Agricultural Research 50(5), 1037-1044.

Chen Y., Randerson J.T., Morton D.C., DeFries R.S., Collatz G.J., Kasibathla P.S., Giglio L., Jin Y.F., Marlier M.E. 2011. Forecasting fire season severity in south America using sea surface temperature Anomalies. Science 334(6057), 787-791.

Cherian, R., Venkataraman, C., Kumar, A., Sarin, M.M., Sudheer, A.K., Ramachandran, S. 2010. Source identification of aerosols influencing atmospheric extinction: Integrating PMF and PSCF with emission inventories and satellite observations. Journal of Geophysical Research - Atmosphere 115: D22212.

Chuvieco, E., Englefield, P., Trishchenko, A.P., \& Luo, Y. 2008a. Generation of long time series of burn area maps of the boreal forest from NOAA-AVHRR composite data. Remote Sensing of Environment 112, 2381-2396.

Chuvieco, E., Giglio, L., Justice, C. 2008b. Global characterization of fire activity: toward defining fire regimes from Earth observation data. Global Change Biology 14 (7), 1488-1502. 
1 Csiszar, I., Denis, L., Giglio, L., Justice, C.O., Hewson, J. 2005. Global fire activity from two years of MODIS data. International Journal of Wildland Fire 14 (2), 117-130.

Csiszar, I.A., Morisette, J.T., Giglio, L. 2006. Validation of active fire detection from moderate-resolution satellite sensors: The MODIS example in northern Eurasia. IEEE Transactions in Geosciences and Remote Sensing 44 (7), 1757-1764.

Davies, D.K., Ilavajhala, S., Wong, M.M., Justice, C.O. 2009. Fire Information for Resource Management System: Archiving and Distributing MODIS Active Fire Data. IEEE Transactions in Geosciences and Remote Sensing 47(1), 72-79.

De Klerk, H. 2008. A pragmatic assessment of the usefulness of the MODIS (Terra and Aqua) 1-km active fire (MOD14A2 and MYD14A2) products for mapping fires in the fynbos biome. International Journal of Wildland Fire 17(2),166-178.

Devineau, J.L., Fournier, A., Nignan, S. 2010. Savanna fire regimes assessment with MODIS fire data: Their relationship to land cover and plant species distribution in western Burkina Faso (West Africa). Journal of Arid Environment 74(9), 1092-1101.

Diagne, M., Drame, M., Ferrao, C., Marchetti, P.G., Pinto, S., Rivolta, G. 2010. Multisource Data Integration for Fire Risk Management: The Local Test of a Global Approach. IEEE Geosciences and Remote Sensing Letters 7(1), 93-97.

DiBella C.M., Fischer M.A., Jobbagy E.G. 2011. Fire pattern in north eastern Argentina: influences of climate and land use/cover. International Journal of Remote Sensing 32(17), 4961-4971.

Dirksen, R.J., Boersma, K.F., de Laat, J., Stammes, P., Van der Werf, G.R., Martin, M.V., Kelder, H.M. 2009. An aerosol boomerang: Rapid around-the-world transport of smoke from the December 2006 Australian forest fires observed from space. Journal of Geophysical Research Atmosphere 114: D21201.

Dlamini, W.M. 2010. A Bayesian belief network analysis of factors influencing wildfire occurrence in Swaziland. Environmental Modelling and Software 25(2), 199-208.

Dubinin, M., Luschekina, A., Radeloff, V.C. 2011. Climate Livestock and Vegetation: What Drives Fire Increase in the Arid Ecosystems of Southern Russia. Ecosystems 14(4), 547-562.

Dubinin, M., Potapov, P., Lushchekina, A., Radeloff, V.C. 2010. Reconstructing long time series of burned areas in arid grasslands of southern Russia by satellite remote sensing. Remote Sensing Of Environment 114(8), 1638-1648.

Duncan, B.N., Bey, I., Chin, M., Mickley, L.J., Fairlie, T.D., Martin, R.V., Matsueda, H. 2003. Indonesian wildfires of 1997: Impact on tropospheric chemistry. Journal of Geophysical Research- Atmosphere108(D15), 4458.

Duncan, B.N., Martin, R.V., Staudt, A.C., Yevich, R., Logan, J.A. 2003. Interannual and seasonal variability of biomass burning emissions constrained by satellite observations Journal of Geophysical Research- Atmosphere 108 (D2), 4100.

Eckmann, T.C., Roberts, D.A., Still, C.J. 2008. Using multiple endmember spectral mixture analysis to retrieve subpixel fire properties from MODIS. Remote Sensing of Environement112(10), 3773-3783.

Eckmann, T.C., Still, C.J., Roberts, D.A., Michaelsen, J.C. 2010. Variations in Subpixel Fire Properties with Season and Land Cover in Southern Africa. Earth Interactions $14,6$.

Ellicott, E., Vermote, E., Giglio, L., Roberts, G. 2009. Estimating biomass consumed from fire using MODIS FRE. Geophysical Research Letters 36, L13401.

Fan, X.H., Chen, H.B., Xia, X.G., Li, Z.Q., Cribb, M. 2010. Aerosol optical properties from the Atmospheric Radiation Measurement Mobile Facility at Shouxian China. Journal of Geophysical Research - Atmosphere 115, D00K33. 
1 Fernandes K., Baethgen W., Bernardes S., DeFries R., DeWitt D.G., Goddard L., Lavado 2 W., Lee DE, Padoch C., Pinedo-Vasquez M, Uriarte M. 2011. North tropical 3 influence on western amazon fire season variability. Geophysical Research Letters 438, L12701.

5 Fiebig, M., Lunder, C.R., Stohl, A. 2009. Tracing biomass burning aerosol from South America to Troll Research Station Antarctica. Geophysical Research Letters 36, L14815.

Fokeeva E.V., Safronov A.N., Rakitin V.S., Yurganov L.N., Grechko E.I., Shumskii R.A. 2011. Investigatioon of the 2010 july-august fire impact on carbon monoxide atmospheric pollution in Moscow and its outskirts, estimating of emissions. Izvestiya Atmosphere and Ocean Physics 47(6), 682-698.

Freeborn, P.H., Wooster, M.J., Roberts, G., Malamud, B.D., Xu, W.D. 2009. Development of a virtual active fire product for Africa through a synthesis of geostationary and polar orbiting satellite data. Remote Sensing of Environment 113(8),1700-1711.

Fuller, D.O., Murphy, K. 2006. The ENSO-fire dynamic in insular Southeast Asia. Climatic Change 74(4), 435-455.

Generoso S. Breon F.M., Balkanski Y., Boucher O., Schulz M. 2003. Improving the seasonal cycle and interannual variations of biomass burning aerosol sources. Atmospherioc Chemistry and Physics 3, 1211-1222.

Giglio, L. 2007. Characterization of the tropical diurnal fire cycle using VIRS and MODIS observations. Remote Sensing of Environment 108(4), 407-421.

Giglio, L., Csiszar, I., Justice, C.O. 2006a. Global distribution and seasonality of active fires as observed with the Terra and Aqua Moderate Resolution Imaging Spectroradiometer (MODIS) sensors. Journal of Geophysical Research Biogeosciences 111(G2), G02016.

Giglio, L., Csiszar, I., Restas, A., Morisette, J.T., Schroeder, W., Morton, D., Justice, C.O. 2008. Active fire detection and characterization with the advanced spaceborne thermal emission and reflection radiometer (ASTER). Remote Sensing of Environment 112(6), 3055-3063.

Giglio, L., Descloitres, J., Justice, C.O., Kaufman, Y.J. 2003. An enhanced contextual fire detection algorithm for MODIS. Remote Sensing of Environment 87, 273-282.

Giglio, L., Kendall, J.D., Mack, R. 2003. A multi-year active fire dataset for the tropics derived from the TRMM VIRS. International Journal of Remote Sensing 24(22), 4505-4525.

Giglio L., Kendall J.D., Tucker C.J. 2000. Remote sensing of fires with the TRMM VIRS. International Journal of Remote Sensing 21(1), 203-207.

Giglio. L., Loboda, T., Roy, D.P., Quayle, B., Justice, C.O. 2009. An active-fire based burned area mapping algorithm for the MODIS sensor. Remote Sensing of Environment113(2), 408-420.

Giglio, L., Randerson, J.T., van der Werf, G.R., Kasibhatla, P.S., Collatz, G.J., Morton, D.C., DeFries, R.S. 2010. Assessing variability and long-term trends in burned area by merging multiple satellite fire products. Biogeosciences 7(3), 1171-1186.

Giglio, L., Van der Werf, G.R., Randerson, J.T., Collatz, G.J., Kasibhatla, P. 2006b. Global estimation of burned area using MODIS active fire observations. Atmospheric Chemistry and Physics 6, 957-974.

Goloub, P., Arino, O. 2000. Verification of the consistency of POLDER aerosol index over land with ATSR-2/ERS-2 fire product. Geophysical Research Letters 27 (6), 899902.

Gomez I., Martin P.M. 2011. Prototyping an artificial neural network for burned area mapping on a regional scale in Mediterranean areas using MODIS images. 
International Journal of Applied Earth Observation and Geoinformation 13(5), 741 752.

Hawbaker, T.J., Radeloff, V.C., Syphard, A.D., Zhu, Z.L., Stewart, S.I. 2008. Detection rates of the MODIS active fire product in the United States. Remote Sensing of Environment 112(5), 2656-2664.

He M., Zheng J.Y., Yin S.S. and Zhang Y.Y. 2011. Trends, temporal and sptial 7 characteristics, and uncertainties in biomass burning emissions in the Pearl river 8 Delta, China. Atmospheric Environment 45(24), 4051-5049.

9 Heinold B., Tegen I., Schepanski K. Tesche M., Esselborn M., Freudenthaler V., Gross S, Kandler K., Knippertz P., Muller D., Schladitz A., Toledano C., Weinzierl B., Ansmann A., Althausen D., Muller T., Petzold A., Wiedensohler A. 2011. Regional modeling of Saharan dust and biomass-burning smoke Part I: Model description and evaluation. Tellus Series B - Chemistry and Physiological Meteorology 63(4), 781-799.

Henderson, S.B., Burkholder, B., Jackson, P.L., Brauer, M., Ichoku, C. 2008. Use of MODIS products to simplify and evaluate a forest fire plume dispersion model for PM10 exposure assessment. Atmospheric Environment 42(36), 8524-8532.

Henderson, S.B., Ichoku, C., Burkholder, B.J., Brauer, M., Jackson, P.L. 2010. The validity and utility of MODIS data for simple estimation of area burned and aerosols emitted by wildfire events. International Journal of Wildland Fire 19(7), 844-852.

Hoelzemann, J.J., Schultz, M.G., Brasseur, G.P., Granier, C., Simon, M. 2004. Global Wildland Fire Emission Model (GWEM): Evaluating the use of global area burnt satellite data. Journal of Geophysical Research - Atmosphere 109(D14), D14S04.

Huang, S., Siegert, F., Goldammer, J.G., Sukhinin, A.I. 2009. Satellite-derived 2003 wildfires in southern Siberia and their potential influence on carbon sequestration. International Journal of Remote Sensing 30(6), 1479-1492.

Huang X., Li M., Friedli H.R., Song Y., Chang D., Zhu L. 2011. Mercury emissions from biomass burning in China. Environmental Science and Technology 45(21): $9442-$ 9448.

Huesca, M., Gonzalez-Alonso, E., Cuevas, J.M., Merino-De-Miguel, S. 2008. Canary Islands burned land mapping using MODIS and HOTSPOT data. Investigacion agrarian - sistemas y recursos forestales 17(3), 308-316.

Hyer, E.J., Reid, J.S. 2009. Baseline uncertainties in biomass burning emission models resulting from spatial error in satellite active fire location data. Geophysical Research Letters 36, L05802.

Ichoku, C., Giglio, L., Wooster, M.J., Remer, L.A. 2008. Global characterization of biomass-burning patterns using satellite measurements of fire radiative energy. Remote Sensing of Environment 112(6), 2950-2962.

In, H.J., Kim, Y.P. 2010. Estimation of the aerosol optical thickness distribution in the Northeast Asian forest fire episode in May 2003: Possible missing emissions. Atmospherical Research 98, 261-273.

Ito, A., and Penner J.E. 2004. Global estimates of biomass burning emissions based on satellite imagery for the year 2000. Journal of Geophysical Research 109, D14S05.

Ito A. and Penner J.E. 2005. Historical emissions of carbonaceous aerosols from biomass and fossil fuel burning for the period 1870-2000. Global Biogeochemical Cycles 19, GB2028.

Ito, A., Akimoto, $\mathrm{H}$ 2007. Seasonal and interannual variations in $\mathrm{CO}$ and $\mathrm{BC}$ emissions from open biomass burning in Southern Africa during 1998-2005.Global Biogeochemical Cycles 21(2), GB2011. 
1 Jain, A.K. 2007. Global estimation of $\mathrm{CO}$ emissions using three sets of satellite data for

2 burned area. Atmospheric Environment 41(33), 6931-6940.

3 Ji Y.M., and Stocker E. 2002a. Seasonal, intraseasonal, and interannual variability of

4 global land fires and their effects on atmopsheric aerosol distribution. Journal of

$5 \quad$ Geophysical Research - Atmosphere 107 (D23), 4697.

$6 \mathrm{Ji}$ Y.M. and Stocker E. 2002b. An overview of the TRMM/TSDIS fire algorithm and

7 product. International Journal of Remote Sensing 23(16), 3285-3303.

8 Justice, C.O., Giglio, L., Korontzi, S., Owens, J., Morisette, J.T., Roy, D., Descloitres, J.,

9 Alleaume, S., Petitcolin, F., Kaufman, Y. 2002. The MODIS fire products. Remote

10 Sensing of Environment 83:244-262.

11 Kalashnikova, O.V., Mills, F.P., Eldering, A., Anderson, D. 2007. Application of satellite

12 and ground-based data to investigate the UV radiative effects of Australian aerosols.

13 Remote Sensing of Environment 107, 65-80.

14 Kasischke, E.S., Hewson, J.H., Stocks, B., van der Werf, G., Randerson, J. 2003. The

15 use of ATSR active fire counts for estimating relative patterns of biomass burning -

16 a study from the boreal forest region. Geophysical Research Letters 30(18),1969.

17 Kasischke, ES., Loboda, T., Giglio, L., French, NHF, Hoy EE., de Jong, B., Riano, D.

18 2011. Quantifying burned area for North American forests: Implications for direct

19 reduction of carbon stocks. Journal of Geophysical Research- Biogeosciences 116,

20 G04003.

21 Kasischke E.S., Penner J.E. 2004. Improving global estimates of atmopsheric emissions from biomass burning. Journal of Geophysical Research 109, D14S01.

Kelha, V., Rauste, Y., Hame, T., Sephton, T., Buongiorno, A., Frauenberger, O., Soini, K., Venalainen., A, San Miguel-Ayanz, J., Vainio, T. 2003. Combining AVHRR and ATSR satellite sensor data for operational boreal forest fire detection. International Journal of Remote Sensing 24(8), 1691-1708.

Kloster S., Mahowald N.M., Randerson J.T., Thornton P.E., Hoffman F.M., Levis S., Lawrence P.J., Feddema J.J., Oleson K.W., Lawrence D.M. 2010. Fire dynamics during the 20th century simulated by the Community Land Model. Biogeosciences 7(6), 1877-1902.

Koren, I., Remer, L.A., Longo, K. 2007. Reversal of trend of biomass burning in the Amazon. Geophysical Research Letters 34(20), L20404.

Korontzi, S. 2005. Seasonal patterns in biomass burning emissions from southern African vegetation fires for the year 2000. Global Change Biology 11(10), 1680-1700.

Korontzi, S., McCarty, J., Justice, C. 2008. Monitoring agricultural burning in the Mississippi River Valley region from the Moderate Resolution Imaging Spectroradiometer (MODIS). Journal of Air and Waste Management Association 58(9), 1235-1239.

Korontzi, S., McCarty, J., Loboda, T., Kumar, S., Justice, C. 2006. Global distribution of agricultural fires in croplands from 3 years of Moderate Resolution Imaging Spectroradiometer (MODIS) data. Global Biogeochemical Cycles 20(2), GB2021.

Korontzi, S., Roy, D.P., Justice, C.O., Ward, D.E. 2004. Modeling and sensitivity analysis of fire emissions in southern Africa during SAFARI 2000. Remote Sensing of Environment 92(2), 255-275.

48 Krawchuk M.A., Moritz M.A. 2011. Constraints on global FIRE activity across a ressource 49 gradient. Ecology 92(1), 121-132. 
1 Krawchuk, M.A., Moritz, M.A., Parisien, MA, Van dorn, J., Hayhoe, K. 2009. Global 2 pyrogeography : the current and future distribution of wildfire. Plos one 4(4), e5102.

3 Kumar SS., Roy D.P., Boschetti L., Kremens R. 2011. Exploiting the power law 4 distribution properties of satellite fire radiative power retrievals: a method to 5 estimate fire radiative energy and biomass burned from sparse satellite 6 observations. Journal of Geophysical Research- Atmosphere 116, D19303.

7 Kumar R., Naja M., Satheesh S.K., Ojha N., Joshi H., Sarangi T., Pant P., Dumka U.C., 8 Hedge P., Venkataramani S. 2011. Influences of the springtime northern Indian 9 biomass burning over the central Himalayas. Journal of Geophysical Research 10 Atmosphere 116, D19302.

11 Kushida, K. 2010. Detection of Active Wildland Fires Using Multitemporal MODIS Images. 12 IEEE Geosciences and Remote Sensing Letters 7(2), 301-305.

13 Langner, A., Miettinen, J., Siegert, F. 2007. Land cover change 2002-2005 in Borneo and 14 the role of fire derived from MODIS imagery. Global Change Biology 13(11), 2329152340

16 Langner, A,, Siegert, F. 2009. Spatiotemporal fire occurrence in Borneo over a period of 1710 years. Global Change Biology 15(1), 48-62.

18 Le Page, Y., Pereira, J.M.C., Trigo, R., da Camara, C., Oom, D., Mota, B. 2008. Global 19 fire activity patterns (1996-2006) and climatic influence: an analysis using the World 20 Fire Atlas. Atmospheric Chemistry and Physics 8(7),1911-1924.

21 Le Page, Y., van der Werf, G.R., Morton, D.C., Pereira, J.M.C. 2010. Modeling fire-driven 22 deforestation potential in Amazonia under current and projected climate conditions. 23 Journal of Geophysical Research - Biogeosciences 115:G03012.

24 Lehsten, V., Harmand, P., Palumbo, I., Arneth, A. 2010. Modelling burned area in Africa. 25 Biogeosciences 7(10), 3199-3214.

26 Lehsten, V., Tansey, K., Balzter, H., Thonicke, K., Spessa, A., Weber, U., Smith, B., 27 Arneth, A. 2009. Estimating carbon emissions from African wildfires. 28 Biogeosciences 6(3), 349-360.

29 Li, B.G., Yuan, H.S., Feng, N., Tao, S. 2010a. Spatial and temporal variations of aerosol 30 optical depth in China during the period from 2003 to 2006. International Journal of $31 \quad$ Remote Sensing 31(7), 1801-1817.

32 Li, H.Y., Han, Z.W., Cheng, T.T., Du, H.H., Kong, L.D., Chen, J.M., Zhang, R.J., Wang,

47 Loboda, T.V. 2009. Modeling fire danger in data-poor regions: a case study from the $48 \quad$ Russian Far East. International Journal of Wildland Fire 18(1), 19-35.

49 Loboda, T.V., Csiszar, I.A. 2007a. Assessing the risk of ignition in the Russian Far East 50 within a modeling framework of fire threat. Ecological Applications 17(3), 791-805. 
1 Loboda, T.V., Csiszar, I.A. 2007b. Reconstruction of fire spread within wildland fire

2 events in Northern Eurasia from the MODIS active fire product. Global Planetary

$3 \quad$ Changes 56, 258-273.

4 Loboda, T., O'Neal, K.J., Csiszar, I. 2007. Regionally adaptable dNBR-based algorithm

5 for burned area mapping from MODIS data. Remote Sensing of Environement

6 109(4), 429-442.

7 Loboda, TV, Hoy, EE Giglio, L., Kasischke, ES_2011. Mapping burned area in Alaska

8 using MODIS data: a data limitations-driven modification to the regional burned

9 area algorithm . International Journal of Wildland Fire. 20 (4), 487-496.

10 Longo, K.M., Freitas, S.R., Andreae, M.O., Setzer, A., Prins, E., Artaxo, P. 2010. The

11 Coupled Aerosol and Tracer Transport model to the Brazilian developments on the

12 Regional Atmospheric Modeling System (CATT-BRAMS) - Part 2: Model sensitivity

13 to the biomass burning. Atmospheric Chemistry and Physics 10(13), 5785-5795.

14 Maeda, E.E., Arcoverde, G.F.B., Pellikka, P.K.E., Shimabukuro, Y.E. 2011. Fire risk

15 assessment in the Brazilian Amazon using MODIS imagery and change vector

16 analysis. Applied Geography 31(1), 76-84.

17 Maeda, E.E., Formaggio, A.R., Shimabukuro, Y.E., Arcoverde, G.F.B., Hansen, M.C.

18 2009. Predicting forest fire in the Brazilian Amazon using MODIS imagery and

19 artificial neural networks. International Journal of Applied Earth Observation and

20 Geoinformation 11(4), 265-272.

21 Mari, C.H., Cailley, G., Corre, L., Saunois, M., Attie, J.L., Thouret, V., Stohl, A. 2008. Tracing biomass burning plumes from the Southern Hemisphere during the AMMA 2006 wet season experiment. Atmospheric Chemistry and Physics 8(14), 39513961.

Mazzoni, D., Logan, J.A., Diner, D., Kahn, R., Tong, L.L., Li, Q.B. 2007. A data-mining approach to associating MISR smoke plume heights with MODIS fire measurements. Remote Sensing of Environment 107,138-148.

McCarty, J.L. 2011. Remote Sensing-Based Estimates of Annual and Seasonal Emissions from Crop Residue Burning in the Contiguous United States. Journal of Air and Waste Management Association 61(1), 22-34.

McCarty, J.L., Justice, C.O., Korontzi, S. 2007. Agricultural burning in the Southeastern United States detected by MODIS. Remote Sensing of Environment 108(2), 151162.

McCarty, J.L., Korontzi, S., Justice, C.O., Loboda, T. 2009. The spatial and temporal distribution of crop residue burning in the contiguous United States. Science of the Total Environment 407(21), 5701-5712.

McCarty, J.L., Loboda, T., Trigg, S. 2008. A hybrid remote sensing approach to quantifying crop residue burning in the United States. Applied Ingineering in Agriculture 24(4), 515-527.

Merino-de-Miguel, S., Huesca, M., Gonzalez-Alonso, F. 2010. Modis reflectance and active fire data for burn mapping and assessment at regional level. Ecological Modelling 221(1), 67-74.

Michel, C., Liousse, C., Gregoire, J.M., Tansey, K., Carmichael, G.R., Woo, J.H. 2005. Biomass burning emission inventory from burnt area data given by the SPOTVEGETATION system in the frame of TRACE-P and ACE-Asia campaigns. Journal of Geophysical Research - Atmosphere 110(D9), D09304.

Miettinen, J., Langner, A., Siegert, F. 2007. Burnt area estimation for the year 2005 in Borneo using multi-resolution satellite imagery. International Journal of Wildland Fire 16(1), 45-53. 
1 Miettinen, J., Shi, C.H., Liew, S.C. 2011. Influence of peatland and land cover distribution

2 on fire regimes in insular Southeast Asia. Regional Environmental Change 11(1),

3 191-201.

4 Mieville, A., Granier, C., Liousse, C., Guillaume, B., Mouillot, F,. Lamarque, J.F., Gregoire,

5 J.M., Petron, G. 2010. Emissions of gases and particles from biomass burning

6 during the 20th century using satellite data and an historical reconstruction.

$7 \quad$ Atmospheric Environment 44(11), 1469-1477.

8 Moffet, R.C., de Foy, B., Molina, L.T., Molina, M.J., Prather, K.A. 2008. Measurement of

9 ambient aerosols in northern Mexico City by single particle mass spectrometry.

10 Atmospheric Chemistry and Physics 8(16), 4499-4516.

11 Morisette, J.T., Giglio, L., Csiszar, I., Justice, C.O. 2005. Validation of the MODIS active

12 fire product over Southern Africa with ASTER data. International Journal of Remote

13 Sensing 26(19), 4239-4264.

14 Morisette, J.T., Giglio, L., Csiszar, I., Setzer, A., Schroeder, W., Morton, D., Justice, C.O.

15 2005. Validation of MODIS active fire detection products derived from two

16 algorithms. Earth Interactions 9, 9.

17 Morton, D.C., DeFries, R.S., Nagol, J., Souza, C.M., Kasischke, E.S., Hurtt, G.C.,

18 Dubayah, R. 2011. Mapping canopy damage from understory fires in Amazon

19 forests using annual time series of Landsat and MODIS data. Remote Sensing of

20 Environment 115(7), 1706-1720.

21 Morton, D.C., Defries, R.S., Randerson, J.T., Giglio, L., Schroeder, W., van Der Werf, 22 G.R. 2008. Agricultural intensification increases deforestation fire activity in 23 Amazonia. Global Change Biology 14(10), 2262-2275.

24 Mota, B.W., Pereira, J.M.C, Oom, D., Vasconcelos, M.J.P., Schultz, M. 2006. Screening 25 the ESA ATSR-2 World Fire Atlas (1997-2002). Atmospheric Chemistry And 26 Physics 6, 1409-1424.

27 Mouillot F. and Field C.B. 2005. Fire history and the global carbon budget: a 1x1 degree

28 fire history reconstruction for the $20^{\text {th }}$ century. Global Change Biology $11,398-420$.

29 Mouillot F. Narasimha A., Balkanski Y., Lamarque J.F., Field C.B. 2006. Global carbon

30 emissions from biomass burning in the $20^{\text {th }}$ century. Geophysical Research Letters

31 33, L01801.

32 Mu M., Randerson J.T., Van der Werf G.R., Giglio L., Kasibathla P., Morton D., Collatz G.J., De Fries R.S., Hyer E.J., Prins E.M., Griffith D.W.T., Wunch D., Toon G.C., Sherlock V., Wennberg P.O. 2011. Daily and 3-hourly variability in global fire emissions and consequences for atmospheric model predictions of carbon monoxide. Journal of Geophysical Research - Atmosphere 116 , D24303.

Pochanart, P., Akimoto, H., Kajii, Y., Sukasem, P. 2003. Carbon monoxide regional-scale transport and biomass burning in tropical continental Southeast Asia: Observations in rural Thailand. Journal of Geophysical Research - Atmosphere 108(D17), 4552. 
1 Prasad, V.K., Badarinath, K.S., Eaturu, A. 2008. Biophysical and anthropogenic controls 2 of forest fires in the Deccan Plateau India. Journal of Environmental Management 3 86(1), 1-13.

4 Prentice I.C., Kelley D.I., Foster P.N., Friedlingstein P., Harrison S.P., Bartlein P.J. 2011.

$5 \quad$ Modelling fire and the terrestrial carbon balance. Global and Biogeochemical Cycles

6 25, GB3005.

7 Pu, R.L., Li, Z.Q., Gong, P., Csiszar, I., Fraser, R., Hao, W.M., Kondragunta, S., Weng,

8 F,Z. 2007. Development and analysis of a 12-year daily 1-km forest fire dataset

9 across North America from NOAA/AVHRR data. Remote Sensing of Environment 10 108(2),198-208.

11 Randerson J.T., Van der Werf G.R., Collatz G.J., Giglio L., Still C.J., Kasibathla P., Miller J.B., White JWC, DeFries R.S., Kasischke E.S. 2005. Fire emissions from C3 and $\mathrm{C} 4$ vegetation and theur influence on interannual variability of atmospheric $\mathrm{CO} 2$ and delta CO2 - 13C. Global Biogeochemical Cycles 19(2), GB2019.

Redo D., Milington A.C., Hinderry D. 2011. Deforestation dynamics and policy changes in Bolivia's post neoliberal era. Land Use Policy 28(1), 227-241.

Reid, J.S., Hyer, E.J., Prins, E.M., Westphal, D.L., Zhang, J.L., Wang, J., Christopher, S.A., Curtis, C.A., Schmidt, C.C., Eleuterio, D.P., Richardson, K.A., Hoffman, J.P. 2009. Global Monitoring and Forecasting of Biomass-Burning Smoke: Description of and Lessons From the Fire Locating and Modeling of Burning Emissions (FLAMBE) Program. IEEE Journal of Selected Topics in Applied Earth Observation and Remote Sensing 2(3), 144-162.

Ressl, R., Lopez, G., Cruz, I., Colditz, R.R., Schmidt, M., Ressl, S., Jimenez, R. 2009. Operational active fire mapping and burnt area identification applicable to Mexican Nature Protection Areas using MODIS and NOAA-AVHRR direct readout data. Remote Sensing of Environment 113(6), 1113-1126.

Rinsland, C.P., Luo, M., Shephard, M.W., Clerbaux, C., Boone, C.D., Bernath, P.F., Chiou, L., Coheur, P.F. 2008. Tropospheric emission spectrometer (TES) and atmospheric chemistry experiment (ACE) measurements of tropospheric chemistry in tropical southeast Asia during a moderate El Nino in 2006. Journal of Quantitative Spectroscopy and Radiative Transfer 109(10),1931-1942.

Robbins, A.M.J., Eckelmann, C.M., Quinones, M. 2008. Forest Fires in the Insular Caribbean.Ambio 37(8), 528-534.

Roberts G.J. and Wooster M.J.2008. Fire detection and Fire characterization over Africa using Meteosat SEVIRI. IEEE Transactions on Geosciences and Remote Sensing 46(4), 1200-1218.

Roberts G., Wooster M., Freeborn P.H., Xu W. 2011. Integratioon of geostationnary FRP and polar Orbiter burned area dataset for an enhanced biomass burning inventory. Remote Sensing of Environment 115(8), 2047-2061.

Romero-Ruiz, M., Etter, A., Sarmiento, A., Tansey, K. 2010. Spatial and temporal variability of fires in relation to ecosystems land tenure and rainfall in savannas of northern South America. Global Change Biology 16(7), 2013-2023.

Roy, B., Pouliot, G.A., Gilliland, A., Pierce, T., Howard, S., Bhave, P.V., Benjey, W. 2007. Refining fire emissions for air quality modeling with remotely sensed fire counts: A wildfire case study. Atmospheric Environment 41(3):655-665.

Roy, D.P., Boschetti, L. 2009. Southern Africa Validation of the MODIS L3JRC and GlobCarbon Burned-Area Products. IEEE Transactions in Geosciences and Remote Sensing 47(4), 1032-1044. 
1 Roy, D.P., Boschetti, L., Justice, C.O., Ju, J. 2008. The collection 5 MODIS burned area product - Global evaluation by comparison with the MODIS active fire product. Remote Sensing of Environment 112(9), 3690-3707.

Roy, D.P., Frost, P.G.H., Justice, C.O., Landmann, T., Le Roux, J.L., Gumbo, K., Makungwa, S., Dunham, K., Du Toit, R., Mhwandagara, K., Zacarias, A., Tacheba, B., Dube, O.P., Pereira, J.M.C., Mushove, P., Morisette, J.T., Vannan, S.K.S., Davies, D. 2005. The Southern Africa Fire Network (SAFNet) regional burned-area product-validation protocol. International Journal of Remote Sensing 26(19), 42654292.

Roy, D.P., Jin, Y., Lewis, P.E., Justice, C.O. 2005. Prototyping a global algorithm for systematic fire-affected area mapping using MODIS time series data. Remote Sensing of Environment 97(2),137-162.

Roy, D.P., Lewis, P.E., Justice, C.O. 2002. Burned area mapping using multi-temporal moderate spatial resolution data - a bi-directional reflectance model-based expectation approach. Remote Sensing of Environment 83,263-286.

Russell-Smith, J., Yates, C.P., Brock, C., Westcott, V.C. 2010. Fire regimes and intervalsensitive vegetation in semiarid Gregory National Park northern Australia. Australian Journal of Botany 58(4), 300-317.

Sa, A.C.L., Pereira, J.M.C., Gardner, R.H. 2007. Analysis of the relationship between spatial pattern and spectral detectability of areas burned in southern Africa using satellite data. International Journal of Remote Sensing 28(16), 3583-3601.

Saarikoski, S., Sillanpaa, M., Sofiev, M., Timonen, H., Saarnio, K., Teinela, K., Karppinen, A., Kukkonen, J., Hillamo, R. 2007. Chemical composition of aerosols during a major biomass burning episode over northern Europe in spring 2006: Experimental and modelling assessments. Atmospheric Environment 41(17), 3577-3589.

Schroeder, W., Morisette, J.T., Csiszar, I., Giglio, L., Morton, D., Justice, C.O. 2005. Characterizing vegetation fire dynamics in Brazil through multisatellite data: Common trends and practical issues. Earth Interactions 9, 13.

Schroeder,W., Ruminski, M., Csiszar, I., Giglio, L., Prins, E., Schmidt, C., Morisette, J. 2008. Validation analyses of an operational fire monitoring product: The Hazard Mapping System. International Journal of Remote Sensing 29(20), 6059-6066.

Schultz, M., Heil, A., Hoelzemann, J., Spessa, A., Thonicke, K., Goldammer, J., Held, A., Pereira, J., and van het Bolscher, M. 2002. Global wildland fire emissions from 1960 to 2000, Global Biogeochemical Cycles 22, GB2002003031.

Schultz, M.G. 2002. On the use of ATSR fire count data to estimate the seasonal and interannual variability of vegetation fire emissions. Atmospheric Chemistry and Physics 2, 387-395.

Schwalm C.R., Williams C.A., Schaefer K., Baker I., Collatz G.J., Rendenbeck C. 2011. Does terrestrial drought explain global $\mathrm{CO}_{2}$ flux anomalies induced by El Niño? Biogeosciences 8(9), 2493-2506.

Seielstad, C.A., Riddering, J.P., Brown, S.R., Queen, L.P., Hao, W.M. 2002. Testing the sensitivity of a MODIS-like daytime active fire detection model in Alaska using NOAA/AVHRR infrared data. Photogrammetric Engineering and Remote Sensing 68(8), 831-838.

Serneels, S., Linderman, M., Lambin, EF. 2007. A multilevel analysis of the impact of land use on interannual land-cover change in East Africa. Ecosystems 10(3), 402418.

Sessions W.R., Fuelberg H.E., Kahn R.A., Winker D.M. 2011. An investigation of methods for injecting emissions from boreal wildfires using WRF-chem during ARCTAS. Atmospheric Chemistry and Physics 11(12), 5719-5744. 
1 Siljander, M. 2009. Predictive fire occurrence modelling to improve burned area estimation at a regional scale: A case study in East Caprivi Namibia. International Journal of Applied Earth Observation and Geoinformation11 (6), 380-393.

Simon, M., Plummer, S., Fierens, F., Hoelzemann, J.J., Arino, O. 2004. Burnt area detection at global scale using ATSR-2: The GLOBSCAR products and their qualification. Journal of Geophysical Research - Atmosphere 109 (D14), D14S02.

Singh, H.B., Anderson, B.E., Brune, W.H., Cai, C., Cohen, R.C., Crawford, J.H., Cubison, M.J., Czech, E.P., Emmons, L., Fuelberg, H.E., Huey, G., Jacob, D.J., Jimenez, J.L., Kaduwela, A., Kondo, Y., Mao, J., Olson, J.R., Sachse, G.W., Vay, S.A., Weinheimer, A., Wennberg, P.O., Wisthaler, A. 2010. Pollution influences on atmospheric composition and chemistry at high northern latitudes: Boreal and California forest fire emissions. Atmospheric Environment 44(36), 4553-4564.

Singh C., Panigrahy S., 2011. Characterisation of residue burning from agricultural system in India using space based observations. Journal of the Indian Society of Remote Sensing 39(3), 423-429.

Small J.D., Jiang J.H., Su H. Zhai C.X. 2011. Relationship between aerosol and cloud fraction over Australia. Geophysical Research Letters 38, L23802.

Smith, R., Adams, M., Maier, S., Craig, R., Kristina, A., Maling, I. 2007. Estimating the area of stubble burning from the number of active fires detected by satellite. Remote Sensing of Environment 109(1), 95-106.

Soja, A.J., Al-Saadi, J., Giglio, L., Randall, D., Kittaka, C., Pouliot, G., Kordzi, J.J., Raffuse, S., Pace, T.G., Pierce, T.E., Moore, T., Roy, B., Pierce, R.B., Szykman, J.J. 2009. Assessing satellite-based fire data for use in the National Emissions Inventory. Journal of Applied Remote Sensing 3, 31504.

Song, Y., Chang, D., Liu, B., Miao, W.J., Zhu, .L, Zhang, Y.H. 2010. A new emission inventory for nonagricultural open fires in Asia from 2000 to 2009. Environmental Research Letters 5(1), 14014.

Song, Y., Liu, B., Miao, W.J., Chang, D., Zhang, Y.H. 2009. Spatiotemporal variation in nonagricultural open fire emissions in China from 2000 to 2007. Global. Biogeochemical Cycles 23, GB2008.

Stavrakou, T., Muller, J.F., De Smedt, I., Van Roozendael, M., van der Werf, G.R., Giglio, L., Guenther, A. 2009a. Evaluating the performance of pyrogenic and biogenic emission inventories against one decade of space-based formaldehyde columns. Atmospheric Chemistry and Physics 9(3), 1037-1060.

Stavrakou, T., Muller, J.F., De Smedt, I., Van Roozendael, M., van der Werf, G.R., Giglio, L., Guenther, A. 2009b. Global emissions of non-methane hydrocarbons deduced from SCIAMACHY formaldehyde columns through 2003-2006. Atmospheric Chemistry and Physics 9 (11), 3663-3679.

Stohl, A., Berg, T., Burkhart, J.F., Fjaeraa, A.M., Forster, C., Herbe,r A., Hov, O., Lunder, C., McMillan, W.W., Oltmans, S., Shiobara, M., Simpson, D., Solberg, S., Stebel, K., Strom, J., Torseth, K., Treffeisen, R., Virkkunen, K., Yttri, K.E. 2007. Arctic smoke record high air pollution levels in the European Arctic due to agricultural fires in Eastern Europe in spring 2006. Atmospheric Chemistry and Physics 7:511-534.

Stroppiana, D., Brivio, P.A., Gregoire, J.M., Liousse, C., Guillaume, B., Granier, C., Mieville, A., Chin, M., Petron, G. 2010. Comparison of global inventories of CO emissions from biomass burning derived from remotely sensed data. Atmospheric Chemistry and Physics 10(24), 12173-12189.

Takahata, C., Amin, R., Sarma, P., Banerjee, G., Oliver, W., Fa, J.E. 2010. RemotelySensed Active Fire Data for Protected Area Management: Eight-Year Patterns in the Manas National Park India. Environmental Management 45(2), 414-423. 
1 Tansey, K., Beston, J., Hoscilo, A., Page, S.E., Hernandez, C.U.P. 2008. Relationship

2 between MODIS fire hot spot count and burned area in a degraded tropical peat swamp forest in Central Kalimantan Indonesia. Journal of Geophysical ResearchAtmosphere 113(D23), D23112.

Tansey, K., Jean-Marie G., Pierre Defourny, Roland Leigh, Jean-François Pekel, Eric van Bogaert, and Etienne Bartholomé. 2008. "A new, global, multi-annual (2000-2007) burnt area product at $1 \mathrm{~km}$ resolution." Geophysical Research Letters 35 (1) , GL031567.

Tansey, K., Jean-Marie Grégoire, Daniela Stroppiana, Adélia Sousa, João Silva, José M. C. Pereira, Luigi Boschetti, et al. 2004. Vegetation burning in the year 2000: Global burned area estimates from SPOT VEGETATION data. Journal of Geophysical Research 109, 22pp.

Thonicke, K., A. Spessa, I. C. Prentice, S. P. Harrison, L. Dong, and C. Carmona-Moreno. 2010. The influence of vegetation, fire spread and fire behaviour on biomass burning and trace gas emissions: results from a process-based model. Biogeosciences 7 (6), 1991-2011.

Tonini, M., Tuia, D., Ratle, F. 2009. Detection of clusters using space-time scan statistics. International Journal of Wildland Fire 18(7), 830-836.

Trigg S.N. and Roy D.P. 2007. A focus group study of factors that promote and constrain the use of satellite-derived products by resource managers in southern Africa. Journal of Environmental Management 82(1), 95-110.

Tulbure, M.G., Wimberly, M.C., Roy, D.P., Henebry, G.M. 2011. Spatial and temporal heterogeneity of agricultural fires in the central United States in relation to land cover and land use. Landscape Ecology 26(2), 211-224.

Turquety, S., Logan, J.A., Jacob, D.J., Hudman, R.C., Leung, F.Y., Heald, C.L., Yantosca, R.M., Wu, S.L., Emmons, L.K., Edwards, D.P., Sachse, G.W. 2007. Inventory of boreal fire emissions for North America in 2004: Importance of peat burning and pyroconvective injection. Jounral of Geophysical Research - Atmosphere 112(D12), D12S03.

Ulevicius, V., Bycenkiene, S., Remeikis, V., Garbaras, A., Kecorius, S., Andriejauskiene, J., Jasineviciene, D., Mocnik, G. 2010. Characterization of pollution events in the East Baltic region affected by regional biomass fire emissions. Atmospheric Research 98,190-200.

Urban, M., Hese, S., Herold, M., Pocking, S., Schmullius, C. 2010. Pan-Arctic Land Cover Mapping and Fire Assessment for the ESA Data User Element Permafrost. Photogrammetrie Fernerkundung und Geoinformation (4), 283-293.

Urbanski, S.P., Salmon, J.M., Nordgren, B.L., Hao, W.M. 2009.A MODIS direct broadcast algorithm for mapping wildfire burned area in the western United States. Remote Sensing of Environment113(11), 2511-2526.

Uriarte M., Yackumic C.B., Cooper T., Flynn D., Cortes M., Crk T., Cullman G., McGinty M., Sircely J. 2009. Expansion of sugarcane production in Sao Paulo, Brazil: implications for fire occurrence and respiratory health. Agriculture Ecosystems and Environment 132, 48-56.

Vadrevu, K.P., Badarinath, K.V.S., Eaturu, A. 2008. Spatio-temporal analysis of fire events in India: implications for environmental conservation. Jounal of Environmental Planning and Management 51(6), 817-832.

Vadrevu, K.P., Ellicott, E., Badarinath, K.V.S., Vermote, E. 2011. MODIS derived fire characteristics and aerosol optical depth variations during the agricultural residue burning season north India. Environmental Pollution 159(6), 1560-1569. 
1 Van der Werf, G.R., Dempewolf J., Trigg, S.N., Randerson, J.T., Kasibhatla, P.S., Giglio,

2 L., Murdiyarso, D., Peters, W., Morton, D.C., Collatz, G.J., Dolman, A.J., DeFries,

3 R.S. 2008a. Climate regulation of fire emissions and deforestation in equatorial Asia.

$4 \quad$ Proceeding of the National Academy of Science - USA. 105(51), 20350-20355.

5 Van der Werf, G.R., Morton, D.C., DeFries, R.S., Giglio, L., Randerson, J.T., Collatz, G.J., Kasibhatla, P.S. 2009. Estimates of fire emissions from an active deforestation region in the southern Amazon based on satellite data and biogeochemical modelling. Biogeosciences 6(2), 235-249.

Van der Werf G.R., Randerson J.T., Collatz G.J., Giglio L. 2003. Carbon emissions from fires in tropical and subtropical ecosystems. Global Change Biology 9(4), 547-562.

Van der Werf G.R., Randerson J.T., Collatz G.J., Giglio L., Kasibathla P.S., Arellano A.F., Olsen S.C., Kasischke E.S. 2004. Continental scale partitioning of fire emissions during the 1997 to $2001 \mathrm{El}$ nino/La Nina period. Science 303(5654), 73-76.

Van der Werf, G.R., Randerson, J.T., Giglio, L., Collatz, G.J., Kasibhatla, P.S., Arellano, A.F. 2006. Interannual variability in global biomass burning emissions from 1997 to 2004. Atmospheric Chemistry and Physics 6, 3423-3441.

Van der Werf, G.R., Randerson, J.T., Giglio, L., Collatz, G.J., Mu, M., Kasibhatla, P.S., Morton, D.C., DeFries, R.S., Jin, Y., van Leeuwen, T.T. 2010. Global fire emissions and the contribution of deforestation savanna forest agricultural and peat fires (1997-2009). Atmospheric Chemistry and Physics 10(23), 11707-11735.

Van der Werf, G.R., Randerson, J.T., Giglio, L., Gobron, N., Dolman, A.J. 2008b. Climate controls on the variability of fires in the tropics and subtropics. Global Biogeochemical Cycles 22(3), GB3028.

Vasileva, A.V., Moiseenko, K.B., Mayer, J.C., Jurgens, N., Panov, A., Heimann, M., Andreae, M.O. 2011. Assessment of the regional atmospheric impact of wildfire emissions based on CO observations at the ZOTTO tall tower station in central Siberia. Journal of Geophysical Research Atmosphere 116, D07301.

Venkataraman, C., Habib, G., Kadamba, D., Shrivastava, M., Leon, J.F., Crouzille, B., Boucher, O., Streets, D.G. 2006. Emissions from open biomass burning in India: Integrating the inventory approach with high-resolution Moderate Resolution Imaging Spectroradiometer (MODIS) active-fire and land cover data. Global Biogeochemical Cycles 20(2), GB2013.

Vivchar A. 2011. Wildfires in Russia in 2000-2008: estimates of burnt areas using the satellite MODIS MCD45 data. Remote Sensing Letters 2(1), 81-90.

Vivchar, A.V., Moiseenko, K.B., Pankratova, N.V. 2010. Estimates of carbon monoxide emissions from wildfires in northern Eurasia for airquality assessment and climate modeling. Izvestiya Atmosphere and Ocean Physics 46(3), 281-293.

Wang, L.L., Qu, J.J., Hao, X.J. 2008. Forest fire detection using the normalized multiband drought index (NMDI) with satellite measurements. Agricultural and Forest Meteorology 148 (11), 1767-1776.

Wang, W.T., Qu, J.J., Hao, X.J., Liu, Y.Q. 2009. Analysis of the moderate resolution imaging spectroradiometer contextual algorithm for small fire detection. Journal of Applied Remote Sensing 3, 31502.

Waring R.H., Coops N.C., Running S.W. 2011. Predicting satellite derived patterns of large scale disturbances in forests of the Pacific Northwest Region in response to recent climatic variation. Remote Sensing of Environment 115, 3554-3566.

Wright S.J, Sanchez-Azofeifa GA, Portillo-Quintero C., Davies D. Poverty and corruption compromise tropical forest reserves. Ecological Application 17(5), 1259-1266. 
1 Xu, W., Wooster, M.J., Roberts, G., Freeborn, P. 2010. New GOES imager algorithms for 2 cloud and active fire detection and fire radiative power assessment across North 3 South and Central America. Remote Sensing of Environment 114(9), 1876-1895.

4 Yurganov L., McMillan W., Grechko E., Dzhola A. 2010. Analysis of global and regional $5 \quad$ CO burdens measured from space between 2000 and 2009 and validated by $6 \quad$ ground based solar tracking spectrometers. Atmospheric Chemistry and Physics 7 10(8), 3479-3494.

8 Zeng, T., Wang, Y.H., Yoshida, Y., Tian, D., Russell, A.G., Barnard, W.R. 2008. Impacts 9 of Prescribed Fires on Air Quality over the Southeastern United States in Spring 10 Based on Modeling and Ground/Satellite Measurements. Environmental Sciences 11 and Technics 42(22), 8401-8406.

12 Zhang, X., Hecobian, A., Zheng, M., Frank, N.H., Weber, R.J. 2010. Biomass burning 13 impact on PM2.5 over the southeastern US during 2007: integrating chemically speciated FRM filter measurements MODIS fire counts and PMF analysis. Atmospheric Chemistry and Physics 10(14), 6839-6853.

Zhang, X.Y., Kondragunta, S., Schmidt, C., Kogan, F. 2008. Near real time monitoring of biomass burning particulate emissions (PM2.5) across contiguous United States using multiple satellite instruments. Atmospheric Environment 42(29), 6959-6972.

19

20

21 